\title{
ANNUAL REPORT TO CONGRESS
}

\section{Department of Energy Activities Relating to the Defense Nuclear Facilities Safety Board}

\section{Calendar Year 1998}

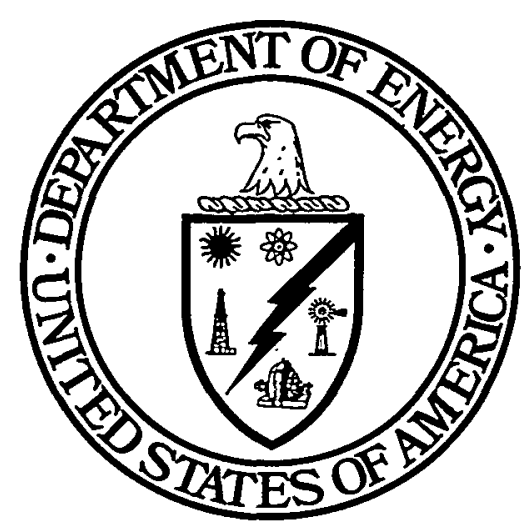

Washington, D.C. 20585 


\section{DISCLAIMER}

Portions of this document may be illegible in electronic image products. Images are produced from the best available original document. 


\section{The Secretary of Energy \\ Washington, DC 20585}

February 1,1999

The Honorable Al Gore, Jr.

President of the Senate

Washington, D.C. 20510

Dear Mr. President:

Section 316(b) of the Atomic Energy Act of 1954 requires the Department of Energy (Department) to submit a written report to Congress addressing the Department's activities related to the Defense Nuclear Facilities Safety Board (Board). I am pleased to forward the Department's Annual Report for Calendar Year 1998.

During 1998, Departmental activities resulted in the proposed closure of one Board recommendation. In addition, the Department has completed all implementation plan milestones associated with four other Board recommendations. Two new Board recommendations were received and accepted by the Department in 1998, and two new implementation plans are being developed to address these recommendations.

The Department also has made significant progress with a number of broad-based initiatives to improve safety. These include expanded implementation and institutionalization of integrated safety management at field sites, a renewed effort to increase the technical capabilities of our federal workforce, and a revised plan for stabilizing excess nuclear materials to achieve significant risk reduction.

If you have any questions, please contact me or have a member of your staff contact Mr. Mark B. Whitaker, Jr., Departmental Representative to the Board, at (202) 5863887.

Yours sincerely,

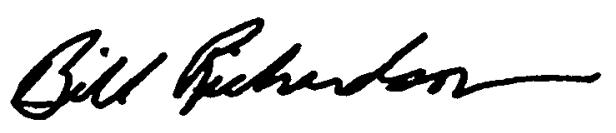

Bill Richardson 


\section{TABLE OF CONTENTS}

\section{LETTER TO CONGRESS}

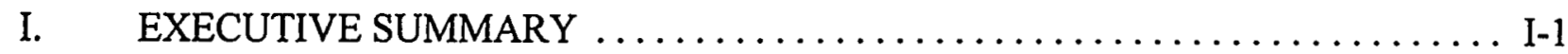

II. KEY DEPARTMENT SAFETY INITIATIVES $\ldots \ldots \ldots \ldots \ldots \ldots \ldots \ldots \ldots$ II-1

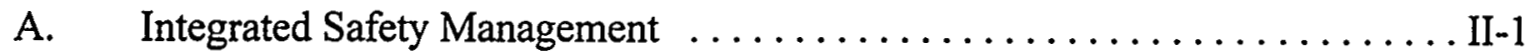

B. Improving Federal Technical Capability ................... II-12

C. Stabilization of Excess Nuclear Materials . . . . . . . . . . . . . . . . . . . . II-15

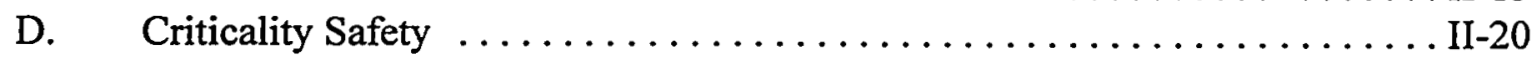

III. IMPLEMENTATION OF BOARD RECOMMENDATIONS . . . . . . . . . . . . III-1

A. Recommendation Closures $\ldots \ldots \ldots \ldots \ldots \ldots \ldots \ldots \ldots \ldots \ldots \ldots \ldots \ldots \ldots$ III -1

B. New Recommendations and Implementation Plans $\ldots \ldots \ldots \ldots \ldots \ldots$ III-3

C. Other Active Implementation Plans . ..................... III-4

D. Report on Implementation Plans Requiring More Than One Year ...... III-28

E. Categorization of Board Recommendations $\ldots \ldots \ldots \ldots \ldots \ldots \ldots$ III-30

IV. OTHER BOARD INTERFACE ACTIVITIES $\ldots \ldots \ldots \ldots \ldots \ldots \ldots \ldots$ IV-1

\section{APPENDICES}

A Orders and Departmental Safety Directives of Interest to the Board $\ldots \ldots \ldots \ldots$ A-1

B Site Visits Supported by the Department in $1998 \ldots \ldots \ldots \ldots \ldots \ldots \ldots$. . . . . . . . .

C Key Department/Board Correspondence in $1998 \ldots \ldots \ldots \ldots \ldots \ldots \ldots$. 


\section{EXECUTIVE SUMMARY}

This is the ninth Annual Report to the Congress describing Department of Energy (Department) activities in response to formal recommendations and other interactions with the Defense Nuclear Facilities Safety Board (Board). The Board, an independent executive-branch agency established in 1988, provides advice and recommendations to the Secretary of Energy regarding public health and safety issues at the Department's defense nuclear facilities. The Board also reviews and evaluates the content and implementation of health and safety standards, as well as other requirements, relating to the design, construction, operation, and decommissioning of the Department's defense nuclear facilities. Figure 1 (page I-6) provides the locations of the major Department facilities.

During 1998, Departmental activities resulted in the proposed closure of one Board recommendation. In addition, the Department has completed all implementation plan milestones associated with four other Board recommendations. Two new Board recommendations were received and accepted by the Department in 1998, and two new implementation plans are being developed to address these recommendations.

The Department has also made significant progress with a number of broad-based initiatives to improve safety. These include expanded implementation of integrated safety management at field sites, a renewed effort to increase the technical capabilities of our federal workforce, and a revised plan for stabilizing excess nuclear materials to achieve significant risk reduction.

\section{Recommendation Proposed for Closure}

Table 1 (page I-7) provides a summary status on Board recommendations. Department activities culminating in 1998 led to the proposed closure of the following Board recommendation:

- Recommendation 92-4, Multi-Function Waste Tank Facility at the Hanford Site

In addition, the Department has completed all of the milestone deliverables in the implementation plans for the following Board recommendations:

- $\quad$ Recommendation 95-1, Improved Safety of Cylinders Containing Depleted Uranium

- Recommendation 94-5, Rules, Orders, and Other Requirements 
- Recommendation 94-3, Rocky Flats Seismic and Systems Safety

- Recommendation 93-6, Nuclear Weapons Expertise

\section{New Recommendations and Implementation Plans}

In 1998 the Department formally accepted two new recommendations received from the Board and is developing implementation plans for these two recommendations (due in March 1999):

- Recommendation 98-2, Safety Management at the Pantex Plant

- Recommendation 98-1, Resolution of Internal Oversight Findings

Implementation plans establish the Department's approach and schedule to resolve the associated safety issues. The Department also developed implementation plan revisions for Board recommendation 93-3, Improving DOE Technical Capability in Defense Nuclear Facilities, and Board recommendation 94-1, Improved Schedule for Remediation. Table 2 (page I-8) provides key dates for active Board recommendations.

\section{Trend in the Number of Open Board Recommendations}

The following trending data illustrate the change in the number of open Board recommendations for each year since the inception of the Board.

\begin{tabular}{|c|c|c|c|c|}
\hline Year & $\begin{array}{c}\text { Recommendations } \\
\text { Issued }\end{array}$ & $\begin{array}{c}\text { Recommendations } \\
\text { Closed }\end{array}$ & $\begin{array}{c}\text { Net Change in Open } \\
\text { Recommendations }\end{array}$ & $\begin{array}{c}\text { Open Recommendations } \\
\text { at Year End }\end{array}$ \\
\hline 1990 & 7 & 0 & +7 & 7 \\
\hline 1991 & 6 & 0 & +6 & 13 \\
\hline 1992 & 7 & 8 & -1 & 12 \\
\hline 1993 & 6 & 1 & +5 & 17 \\
\hline 1994 & 5 & 1 & +4 & 21 \\
\hline 1995 & 2 & 6 & -4 & 17 \\
\hline 1996 & 1 & 4 & -3 & 14 \\
\hline 1997 & 2 & 1 & +1 & 15 \\
\hline 1998 & 2 & $1 *$ & +1 & 16 \\
\hline
\end{tabular}

- Department proposed closure of recommendation $92-4$ on December 16,1998 
The above data reflect the evolution of the recommendation process. Initially, Board recommendations primarily addressed specific, highly technical significant safety issues within the Department's activities. Over time, the Board and the Department have worked cooperatively to address these risks, and to establish fundamental, integrated programs to improve the Department's overall safety management process. Success in this area, combined with an increased use of letters and other communication methods, has led to the issuance of fewer but more broad-based recommendations in recent years. A corresponding reduction in the number of recommendations closed per year reflects the fact that these recommendations are more complex in scope. However, the Department intends to continue to pursue closure of applicable recommendations as a priority in 1999. This will allow the Department to focus resources on resolution of the fundamental safety issues addressed by the remaining open recommendations or identified through other mechanisms.

\section{Summary of the Department's Major Safety Accomplishments}

Concrete accomplishments over the past four years that have contributed to improved safety at Department facilities include the following:

- Identifying over 740 critical skill federal technical positions, and taking action to preserve this capability against the potential adverse affects of downsizing activities;

- Developing and accelerating the implementation of a Department-wide safety management system at ten priority facilities;

- Extending the scope of the integrated safety management program where it is appropriate to all Department facilities;

- Improving the technical capability of the Department's federal work force;

- Promulgating and implementing new safety orders and rules;

- Stabilizing the majority of high risk excess nuclear materials;

- $\quad$ Establishing qualified Facility Representatives at key sites and facilities;

- Institutionalizing highly effective Operational Readiness Reviews; 
- Instituting contract reform to clarify safety management expectations for Department contractors;

- Archiving irreplaceable expertise and experience on criticality, weapons operation, and testing;

- Formalizing the safety roles and responsibilities throughout the Department by issuing the Functions, Responsibilities, and Authorities Manuals; and

- Developing a process to improve the effectiveness of the criticality safety program.

\section{Department Focus for 1999}

In 1999, the Department intends to keep focus on assuring that existing implementation plans remain valid and workable, managing plan actions to completion by the identified plan due dates, and proposing closure of recommendations when the underlying safety issues are resolved. The most significant challenges involve safety issues which are complex-wide in nature and involve culture changes:

- $\quad$ systematically institutionalizing a consistent safety management system which integrates all elements of safety (e.g., public health, occupational safety, environmental protection) into management and work practices at all levels so that work can be accomplished while protecting the public, the worker, and the environment,

- $\quad$ sustaining progress on stabilizing excess nuclear material and identifying ultimate disposition pathways,

- implementing an integrated, Department-wide material disposition process,

- $\quad$ institutionalizing improvements in the effectiveness of the criticality safety program, and

- continuing progress toward effective recruitment, technical qualification, training, and retention of the Department's federal work force.

The above listed items are long-term issues which will take a dedicated, multi-year effort to successfully resolve. The Department is committed to these ongoing efforts and does not foresee major shifts or re-direction in these core safety initiatives, thus providing 
continuity of direction for headquarters, field, and contractor organizations. The primary challenge associated with these safety initiatives continues to be the need to effectively integrate them in a manner that assures a consistent level of protection.

\section{Report Preview}

The remaining portions of the annual report provide the contents described below:

- $\quad$ Section II, KEY DEPARTMENT SAFETY INITIATIVES, describes broad-based Department activities which affect health, safety, and the environment;

- Section III, IMPLEMENTATION OF BOARD RECOMMENDATIONS, describes Department activities completed in 1998 to implement Board recommendations accepted by the Secretary; and

- Section IV, BOARD INTERFACE INITIATIVES, describes Department activities to maintain communications and improve interaction between the Department and the Board. 


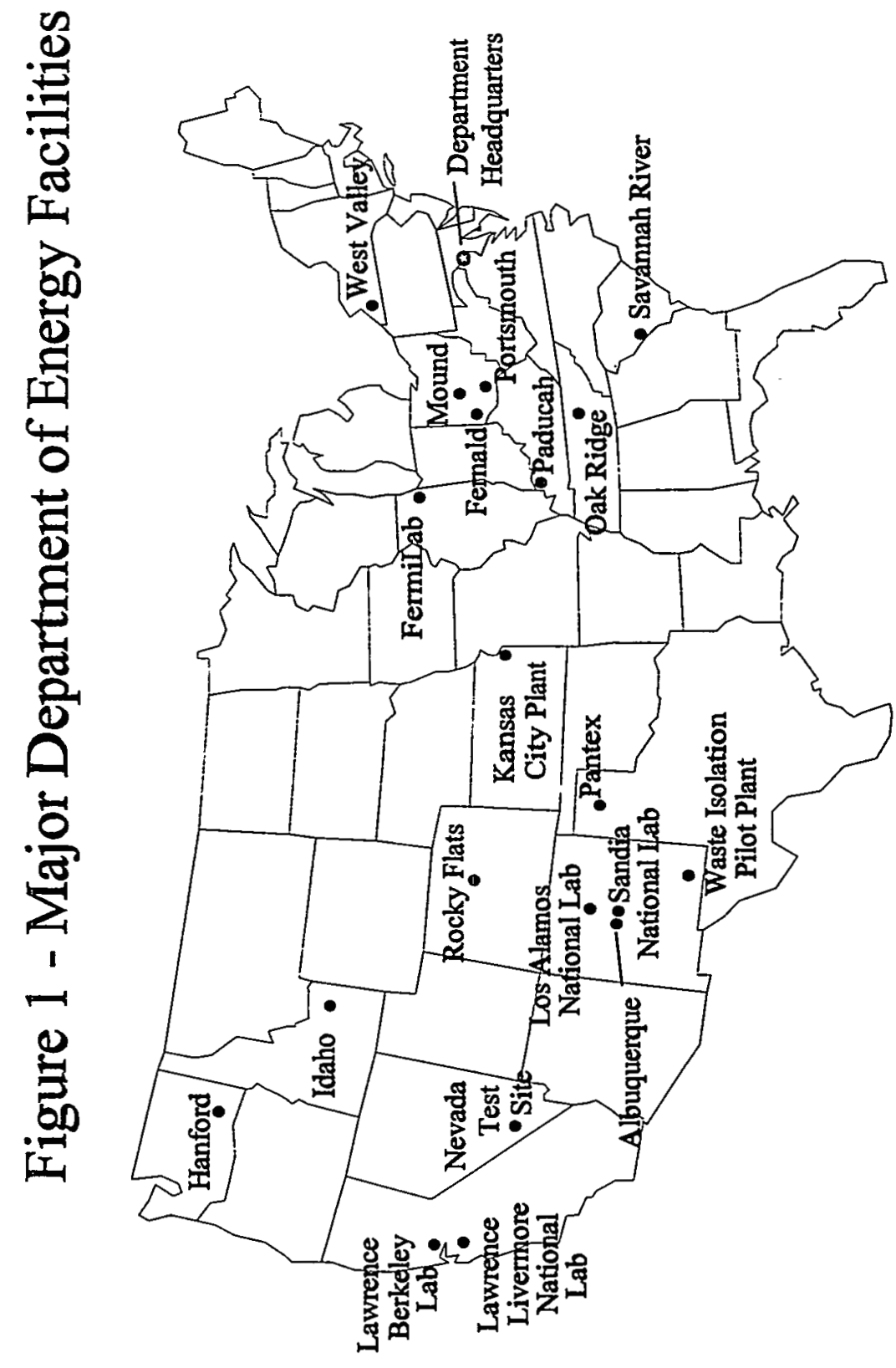


1998 Annual Report to Congress

Table 1

Summary Status of Board Recommendations

\begin{tabular}{|c|c|c|c|}
\hline REC & SUBJECT & OPEN & CLOSED \\
\hline $90-1$ & Savannah River Operator Training & & 10/27/92 \\
\hline $90-2$ & Codes and Standards & & $10 / 24 / 95$ \\
\hline $90-3$ & Hanford Waste Tanks & & $5 / 1 / 92$ \\
\hline $90-4$ & Rocky Flats Operational Readiness Reviews & & $2 / 16 / 95$ \\
\hline $90-5$ & Systematic Evaluation Plans & & $10 / 24 / 95$ \\
\hline 90-6 & Rocky Flats, Plutonium in the Ventilation Ducts & & $10 / 24 / 95$ \\
\hline $90-7$ & Hanford Waste Tanks - Ferrocyanide Safety Issue & & $9 / 4 / 96$ \\
\hline $91-1$ & Safety Standards Program & & $10 / 27 / 92$ \\
\hline $91-2$ & Reactor Operations Management Plan at Savannah River & & $10 / 27 / 92$ \\
\hline $91-3$ & Waste Isolation Pilot Plant & & $10 / 27 / 92$ \\
\hline $91-4$ & Rocky Flats, Building 559 Operational Readiness Review & & $5 / 1 / 92$ \\
\hline $91-5$ & Savannah River K Reactor Power Limits & & $4 / 7 / 93$ \\
\hline $91-6$ & Radiation Protection & & $11 / 8 / 96$ \\
\hline $92-1$ & Operational Readiness of the HB-Line at Savannah River & & $10 / 27 / 92$ \\
\hline $92-2$ & Facility Representatives & & $9 / 17 / 96$ \\
\hline $92-3$ & HB-Line Operational Readiness Reviews at Savannah River & $\dot{-}$ & $2 / 3 / 93$ \\
\hline $92-4$ & Multi-Function Waste Tank Facility at Hanford & & $12 / 16 / 98 *$ \\
\hline $92-5$ & Discipline of Operations & & $10 / 24 / 95$ \\
\hline $92-6$ & Operational Readiness Reviews & & $10 / 24 / 95$ \\
\hline $92-7$ & Training and Qualification & & $11 / 4 / 93$ \\
\hline 93-1 & Standards Utilization in Defense Nuclear Facilities & $\mathrm{X}$ & \\
\hline $93-2$ & Critical Experiments Capability & & $12 / 30 / 97$ \\
\hline $93-3$ & Improving Technical Capability & $\mathrm{X}$ & \\
\hline $93-4$ & Environmental Restoration Management Contracts & & $6 / 28 / 96$ \\
\hline $93-5$ & Hanford Waste Tanks Characterization Studies & $\mathbf{x}$ & \\
\hline 93-6 & Nuclear Weapons Expertise & $\mathrm{X}$ & \\
\hline 94-1 & Improved Schedule for Remediation & $\mathrm{X}$ & \\
\hline $94-2$ & Safety Standards for Low Level Waste & $\mathrm{X}$ & \\
\hline $94-3$ & Rocky Flats Seismic and Systems Safety & $\mathrm{X}$ & \\
\hline $94-4$ & Deficiencies in Criticality Safety at Oak Ridge Y-12 & $\mathrm{X}$ & \\
\hline $94-5$ & Rules, Orders, and Other Requirements & $\mathrm{X}$ & \\
\hline $95-1$ & Improved Safety of Cylinders Containing Depleted Uranium & $\mathrm{X}$ & \\
\hline $95-2$ & Safety Management & $\mathrm{X}$ & \\
\hline $96-1$ & In-Tank Precipitation System at Savannah River & $\mathrm{X}$ & \\
\hline $97-1$ & Safe Storage of Uranium-233 & $\mathrm{x}$ & \\
\hline $97-2$ & Criticality Safety & $\mathrm{x}$ & \\
\hline $98-1$ & Resolution of Internal Oversight Findings & $\mathrm{X}$ & \\
\hline $98-2$ & Safety Management at the Pantex Plant & $\mathrm{X}$ & \\
\hline
\end{tabular}

Date of the Department's letter proposing closure 
Table 2

Key Dates For Active Board Recommendations

\begin{tabular}{||l|l|c|c|c||}
\hline REC & \multicolumn{1}{|c|}{ SUBJECT } & $\begin{array}{c}\text { REC } \\
\text { DATE }\end{array}$ & $\begin{array}{c}\text { RESPONSE } \\
\text { DATE }\end{array}$ & $\begin{array}{c}\text { IMPL. } \\
\text { PLAN } \\
\text { DATE }\end{array}$ \\
\hline $93-1$ & Standards Utilization in Defense Nuclear Facilities & $1 / 21 / 93$ & $4 / 22 / 93$ & $7 / 19 / 93$ \\
\hline $93-3$ & Improving Technical Capability & $6 / 1 / 93$ & $6 / 23 / 93$ & $\begin{array}{c}5 / 5 / 98 \\
\text { (Rev.1) }\end{array}$ \\
\hline $93-5$ & Hanford Waste Tanks Characterization Studies & $7 / 19 / 93$ & $8 / 31 / 93$ & $\begin{array}{c}6 / 17 / 96 \\
\text { (Rev. } 1 \text { ) }\end{array}$ \\
\hline $93-6$ & Nuclear Weapons Expertise & $12 / 10 / 93$ & $2 / 2 / 94$ & $\begin{array}{c}2 / 13 / 96 \\
\text { (Rev. } 1)\end{array}$ \\
\hline $94-1$ & Improved Schedule for Remediation & $5 / 26 / 94$ & $8 / 31 / 94$ & $\begin{array}{c}12 / 28 / 98 \\
\text { (Rev. } 1 \text { ) }\end{array}$ \\
\hline $94-2$ & Safety Standards for Low-Level Waste & $9 / 8 / 94$ & $10 / 28 / 94$ & $\begin{array}{c}5 / 7 / 96 \\
\text { (Rev. } 1)\end{array}$ \\
\hline $94-3$ & Rocky Flats Seismic and Systems Safety & $9 / 26 / 94$ & $11 / 18 / 94$ & $6 / 30 / 95$ \\
\hline $94-4$ & Deficiencies in Criticality Safety at Oak Ridge Y-12 & $9 / 27 / 94$ & $11 / 18 / 94$ & $2 / 24 / 95$ \\
\hline $94-5$ & Rules, Orders, and Other Requirements & $12 / 29 / 94$ & $2 / 21 / 95$ & $7 / 21 / 95$ \\
\hline $95-1$ & Improved Safety of Cylinders Containing Depleted & $5 / 5 / 95$ & $6 / 29 / 95$ & $10 / 16 / 95$ \\
\hline $95-2$ & Safety Management & $10 / 11 / 95$ & $1 / 18 / 96$ & $4 / 18 / 96$ \\
\hline $96-1$ & In-Tank Precipitation System at Savannah River & $8 / 14 / 96$ & $9 / 16 / 96$ & $11 / 12 / 96$ \\
\hline $97-1$ & Safe Storage of Uranium-233 & $3 / 3 / 97$ & $4 / 25 / 97$ & $9 / 29 / 97$ \\
\hline $97-2$ & Criticality Safety & $5 / 19 / 97$ & $7 / 14 / 97$ & $12 / 12 / 97$ \\
\hline $98-1$ & Resolution of Internal Oversight Findings & $9 / 28 / 98$ & $11 / 20 / 98$ & March 99 \\
\hline $98-2$ & Safety Management at the Pantex Plant & $9 / 30 / 98$ & $11 / 20 / 98$ & March 99 \\
\hline
\end{tabular}




\section{KEY DEPARTMENT SAFETY INITIATIVES}

Each of the key initiatives described below involves significant changes from past operating practices. They involve systems-based solutions, cross-organizational/site integration, cross-program integration, and fundamental culture changes to address the underlying safety and management issues. For example, Department determinations about ultimate pathways and long-term dispositions for hazardous materials require deliberate study and integration across the defense nuclear facilities complex. Funding and management of Department-wide efforts to maintain strong criticality prediction and control capabilities requires cross-program coordination. The ongoing transition from expert-based safety management to requirements-based safety management systems continues to be a significant cultural adjustment which needs to be achieved in all parts and at every level of the organization. These changes undo many years of practices developed by sites, facilities, programs, and organizations operating largely independently and autonomously. Nevertheless, the Department is making progress overcoming these difficult challenges to establish a safety culture which is systemsbased, requirements-based, and integrated across programs, organizations, and facilities.

\section{A. Integrated Safety Management}

Department leadership is committed to implementing Integrated Safety Management as the cornerstone of the Department's effort to establish a comprehensive framework for ensuring safety at the Department's defense nuclear facilities. Secretary Richardson, former Secretary Peña, and former Deputy Secretary Moler each demonstrated their strong support of the Department's continuing policy during the course of the year. The Department's independent Office of Oversight has closely followed the implementation of Integrated Safety Management and has kept senior management informed of its progress.

Throughout 1998, the Department vigorously implemented safety management systems, not only at the ten priority facilities, as identified in the Department's April 18, 1996, Implementation Plan, but also at many other facilities that conduct hazardous operations, including some of the national laboratories. During this year, the Department capitalized on lessons learned in conducting the first safety management system implementation verifications at Savannah River in late 1997 and at the Rocky Flats and Hanford sites in early 1998 to develop a more streamlined approach to the conduct of verifications. The Department continued to expand the scope of the program such that, at year end, it encompassed all defense facilities, as well as the remainder of the Department's facilities that conduct hazardous operations. 
The guiding principles for the integrated safety management program remained unchanged:

Line management is responsible for safety;

Clear roles and responsibilities must be articulated;

Competence must be commensurate with responsibilities assigned;

Balanced priorities must be set;

Safety standards and requirements must be identified;

Hazard controls must be tailored to the work being performed; and,

Operations must be authorized.

Schedules for implementation of integrated safety management at each of the priority facilities were refined and updated as the year progressed. The schedules for these facilities at year's end accurately reflected progress to date and expectations for the near future, and were in concert with the Department's Strategic Plan goal to have implementation completed at these ten facilities by the beginning of fiscal year 2000. In addition, the August 1997 safety management-related revisions to the Department of Energy Acquisition Regulation (DEAR), which, in part, required the adoption of a safety management system by all major management and operations (M\&O) contractors, were incorporated into all such M\&O contracts by the end of 1998 .

The Functions, Responsibilities, and Authorities Manuals (FRAMs), developed in the latter half of 1997, were revised and updated for Department headquarters and for the applicable program and field offices associated with the ten priority facilities. The remaining operations offices having defense facilities completed their respective FRAMs in 1998. The emphasis during 1998 was on FRAM usage, not only to encourage the shift in safety management culture required throughout the Department to implement safety management systems effectively, but also to identify any possible organizational conflicts that could be addressed in the first major update. The FRAM development and subsequent upgrading effort were necessary to ensure the emplacement of the solid, functioning, organizational infrastructure that now serves as the foundation for the Department's integrated safety management program.

Considerable progress was achieved during 1998 in tailoring the implementation of safety management systems to the missions and needs of the particular sites and facilities. The tailoring guidance in the Integrated Safety Management System Guide, G450.4, (ISMS Guide) was used by each site in shaping its system, while maintaining fidelity to the five core safety management system functions below that are to be applied in a continuous cycle to address the type of work activities and the hazards involved: 
Define the scope of work

Analyze the hazards

Develop and implement hazard controls

Perform work within those controls

Provide feedback and continuous improvement

The ISMS Guide comprehensively explains the Department's program and provides guidance to managers for system implementation at different types of Departmental facilities and activities. Not prescriptive, the ISMS Guide recognizes that the Department's various missions involve widely varying degrees of risk and hazard, and that a "one size fits all" approach will not succeed. As 1998 ended, a major, first revision to the ISMS Guide had been issued in draft form, with a projected promulgation date of early 1999.

\section{Verification of Integrated Safety Management System Implementation}

The emphasis during 1998 was on implementation with subsequent verification. A draft Integrated Safety Management System Verification Team Leader's Handbook was published in February 1998. This handbook explains the verification concept in great detail and outlines the verification team leader and team member selection process. Team leaders currently are selected by the Head of Contracting Activity (HCA) from a list of senior Departmental employees who have prior verification team experience and are approved by the Director, Safety Management Implementation Team. Team leaders report directly to the HCA at a site, who is normally also the Operations or Field Office Manager (i.e., the responsible line manager). Team members are selected by the team leader based upon:

Established expertise in their intended area(s) of review Appraisal experience

Familiarity with the mission and processes to be reviewed

Training on integrated safety management system policy and expectations

The Team Leader's Handbook contains sample Criteria and Review Approach Documents (CRAD) that have been refined over the last year and will be promulgated in the first formal issuance of the handbook, currently scheduled for February 1999. These criteria are drawn from a group of core requirements that, if met, will ensure a satisfactorily integrated safety management system plan has been proposed for implementation, and that, when implemented, will result in conditions in which work can be accomplished safely. 
The verification process is normally conducted in two steps, although these steps may be combined, when appropriate, by the site's HCA. A Phase I verification consists primarily of a review of the site's or facility's documented safety management system description, which is required by the revised Department of Energy Acquisition Regulation (DEAR). Phase II verification consists of a review of the implementation of that system at the site and its facilities. In 1998, the pace of verification reviews accelerated substantially, with verifications conducted at the following sites:

Rocky Flats Environmental Technology Site

Hanford's K-Basins

Hanford's Tank Waste Remediation System (TWRS)

Oak Ridge's Y-12 Plant

Waste Isolation Pilot Plant

Pacific Northwest National Laboratory

Stanford Linear Accelerator Center

West Valley Demonstration Project

Pantex Plant

Sandia National Laboratories

Savannah River

Lawrence Berkeley National Laboratory

\section{Lessons Learned Workshops}

Two very successful Integrated Safety Management Lessons Learned Workshops were conducted during 1998, one in Albuquerque, New Mexico, and the second in New Orleans, Louisiana. Line managers and environment, safety and health officials from every Department of Energy entity across the complex were represented at each workshop, with approximately 350 and 420 personnel participating in the respective workshops. These two workshops were useful in providing forums for sharing the lessons learned from implementing tailored integrated safety management systems across the complex. Deputy Secretary Moler and Secretary Richardson provided strong presentations at these workshops clarifying vision and expectations for implementing integrated safety management throughout the Department.

\section{Future Emphasis is on "Institutionalization"}

As of December 1998, the Department has conducted sufficient verifications and lessons learned sharing workshops to conclude that sufficient top-level infrastructure supporting integrated safety management is now in place at all major sites and facilities. With September 2000 recently established as the goal for Departmental institutionalization of 
integrated safety management, future efforts will focus mainly on: continuing implementation verification activities; ensuring that organizations have a functioning, fully integrated infrastructure supportive of integrated safety management principles and functions; and transitioning leadership of the Departmental effort to an appropriate Headquarters organization that will exercise the day-to-day management of the Department's efforts in this continuing thrust. Additional focus is being placed on the integrated safety management core function to provide feedback and continuous improvement.

\section{Efforts to Improve Feedback and Continuous Improvement}

In June 1998, the Department prepared an action plan outlining its program for assessing work performance and tracking related to corrective actions. The Department recognized that these feedback and continuous improvement activities are an essential feature of an integrated safety management system and is committed to strengthening the use of feedback and operating experience to improve the safety of its operations.

The path forward is focused on four areas: (1) accelerating implementation of Department of Energy Policy P450.5, Line Environment, Safety and Health Oversight; (2) improving the Department's tracking and follow-up processes; (3) improving the Department's lessons learned processes; and (4) improving implementation of the Department's FRAM. Progress is as follows:

The Department has accelerated implementation of Policy P 450.5 through a workshop conducted on the subject, emphasis from the Office of the Secretary, safety management description reviews, and subsequent verifications.

The Department is reviewing the corrective action and tracking processes used in the complex and is integrating the recommendations of the review group with the approach being developed in response to Board recommendation 98-1, which addresses effective resolution of internal oversight findings.

The Department Standards Committee, under the Assistant Secretary for Environment, Safety and Health, is studying the Department's lessons learned processes.

Recommendations for improvement are expected in early 1999.

The Department's FRAMs were reviewed. An analysis of the safety feedback and improvement function, conducted by a specifically tasked team, was conducted and completed in December 1998. Recommendations for improvement are being incorporated into the next revision to the FRAMs. 


\section{Implementation Progress in the Field}

The overall objective of integrated safety management is to do work safely. The focus of the system's principles and functions is on actual work performance. The planning, analysis, and follow-up activities are designed to ensure work is performed in a manner that protects the health and safety of the worker, the public, and the environment. The ten priority facilities for implementation, as detailed in the Department's Implementation Plan, fall under the aegis of seven site managers, as follows:

Savannah River Site // F- and H-Canyons

Rocky Flats Environmental Technology Site // Buildings 371 and 771

Hanford Site // K-Basins and Tank Farms

Oak Ridge Site // Y-12 Plant

Pantex Site // Bays and Cells

Los Alamos National Laboratory // Technical Area-55 (TA-55) and the Chemical Metallurgical Research Facility (CMR)

Lawrence Livermore National Laboratory // Building 332 (the "Superblock")

Highlights of safety management implementation activities in 1998 are summarized below by the responsible Operations or Field Office for these and other facilities across the Department's defense nuclear facilities complex.

\section{Albuquerque Operations Office.}

\section{Sandia National Laboratories (SNL)}

Sandia National Laboratories completed ISMS implementation by October 1998 as scheduled in the approved ISMS Implementation Plan. Milestones included ISMS implementation within individual SNL divisions and improvements to incorporate selfassessment and standards/requirements identification processes. The Kirtland Area Office and the Albuquerque Operations Office developed a verification approach for ISMS at SNL. Following a Phase I and Phase II verification in November 1998, the AL Manager approved the SNL ISMS description and directed SNL to respond to the opportunities for improvement and recommendations identified in the ISMS verification report.

\section{$\underline{\text { Pantex Plant }}$}

Pantex Plant completed a Phase I and Phase II ISMS verification during August and September of 1998. The High Explosives (HE) and Special Nuclear Material (SNM) 
portions of work described within the ISMS description were verified as adequately described and implemented. Nuclear Explosive Operations must go through a limited scope ISMS re-verification upon completion of corrective actions associated with the Opportunities for Improvement (OPIs) and recommendations identified during the verification. Mason \& Hanger Corporation (MHC) submitted a corrective action plan to the Department on December 9,1998, to address the ISMS verification OPIs and recommendations. The majority of the OPIs related to the MHC ISMS description will be addressed by March 31,1999. Pending successful completion of those items, the Department will repeat a portion of the Phase I review, scoped consistent with previous findings or problems noted. MHC plans to be ready for a limited scope Phase II review, 90 days following Department approval of their ISMS description.

\section{Los Alamos National Laboratories (LANL)}

Los Alamos National Laboratory completed 54 milestones in its development of an ISM system. Within these milestones the major accomplishments at each of the 20 facility management units were refinement of facility/tenant agreements, development of facility safety plans, development of safe work practices, and prioritization of the implementation scheduling of 27 Laboratory Implementing Requirements that further define the ISM system at LANL.

Additionally, the FY 1998 special assessment was completed, focusing on the implementation status of a key list of eight ISM milestones. Four ISM change control board meetings occurred as scheduled in 1998. Within these meetings, approximately 15 enhancements were made within the original set of work smart standards at LANL. In September 1998 a complete refinement of the ISM system description for LANL was approved by the Albuquerque Operations Office Manager. Within this system description is a commitment to start ISMS verification efforts in FY 1999.

\section{Kansas City Plant (KCP)}

The Allied Signal's ISMS description, which consists of an environment, safety and health (ES\&H) management plan, operating system requirements, and site-specific performance measures is submitted to the Kansas City Area Office and Albuquerque Operations Office for approval annually. The FY1999 plan was approved by the AL Manager in December 1998. Allied Signal's ISM confirmation cycle process for validating safe work practices has been approved by the Kansas City Area Office and the Albuquerque Operations Office. The Albuquerque Operations Office has completed the ISMS elements review required by the ISMS confirmation cycle. This is the equivalent of a Phase I review for a nonnuclear industrial facility 
Idaho Operations Office. The Idaho National Engineering and Environmental Laboratory site's prime contract incorporated the safety management-related DEAR clauses in February 1998. The Idaho Operations Office issued its FRAM in August 1998. Lockheed Martin Idaho Technologies Company submitted its proposed safety management system description document and implementation plan in August 1998. The site will conduct a site-wide Integrated Safety Management System Phase I verification, and a Phase II verification for selected facilities, in 1999. In 1998, the Department announced its intention to recompete the site's prime contract. The new contract structure will be similar to the existing contract arrangement, and is scheduled to be awarded to a single Management and Operating contractor in June 1999. The Request for Proposal reflects the site's commitment to implementation of an effective and sustaining safety management system.

Nevada Operations Office. The Nevada Operations Office has approved its safety management FRAM and has incorporated it into their local Supplemental Directive System as a Manual, NV M 411.1-1, dated 4/30/98. Three Nevada contracts include the integrated safety management acquisition requirements DEAR clauses. Two of these contracts include Nevada complex-wide Work Smart Standards (Bechtel Nevada, Inc., plus the recently awarded contract to Wackenhut Services, Inc., effective October 1, 1998). Bechtel Nevada has realigned its company procedures to implement Work Smart Standards, as established in its contract.

The Nevada Operations Office has approved a directive that standardizes the local process and content for Authorization and Activity Agreements for Facilities and Operations, NV M 450.X, dated September 17, 1998. Six Activity Agreements have been developed consistent with NV M 450.X. Three Activity Agreements are being established for facilities of interest to the Board. These facilities include the Device Assembly Facility, waste management facilities, and the U1a complex where subcritical experiments are conducted at the Nevada Test Site. Three other Activity Agreements are being established as a result of potential operational safety risks/concerns, at the direction of the Nevada Operations Office Manager. These facilities include the Big Explosive Experiment Facility, the Hazardous Materials Spill Center, and the Defense Threat Reduction Agency Tunnel Complexes at the Nevada Test Site. The Nevada Operations Office will scope a verification review of the Bechtel Nevada safety management system description and its implementation site-wide and at certain facilities of interest that have Activity Agreements. The verification reviews of Bechtel Nevada and the National Laboratories' activities at Nevada Test Site are in a preliminary planning phase and are tentatively scheduled to occur in the March/April 1999 time frame. 
A charter for the Nevada Operations Office's Work Smart Standards Change Review Group was established March 31, 1998, to pilot the development of an institutionalized Work Smart Standards Change control process. The Review Group represents the convened group of contractor and Nevada Operations Office representatives for the local community who have adopted the complex-wide Work Smart Standards by contract or agreement. The Review Group, lead by the Nevada Acting Deputy Manager, is facilitating the control of Work Smart Standards and is serving as a forum to ensure contractors have an opportunity to identify concerns and reach consensus with Nevada Operations Office on appropriate changes to Work Smart Standards in their contracts.

Oak Ridge Operations Office. Oak Ridge has incorporated the DEAR clauses into its 11 direct contracts, and is ensuring that the clauses are incorporated into all new direct contracts, as directed by Department of Energy Acquisition Letter 97-07. All but two of its newest contractors have submitted integrated safety management system descriptions, and these two new contractors (Foster Wheeler Environmental Corporation and East Tennessee Materials \& Energy Corporation) will submit descriptions during 1999. A Phase I/II Integrated Safety Management Verification was performed at the Y-12 Plant during August of 1998. The Headquarters Office of Environment, Safety, and Health performed a follow-on safety management audit at the Y-12 Plant during November 1998, and the report is due in January 1999. Two of Oak Ridge's other largest contractors, Lockheed Martin Energy Research Corporation (LMER) and Bechtel Jacobs Company LLC, have scheduled Phase I and II verifications during 1999. Oak Ridge Operations Office is working with its smaller contractors to schedule verifications during 1999.

The Y-12 Plant has five approved authorization agreements, with a sixth authorization agreement scheduled for submission after the Basis for Interim Operations for Building 9206 is submitted during the first quarter of CY 1999. Bechtel Jacobs Company LLC has submitted three authorization agreements for the Cylinder Yard Project (one for each site), and two of these were approved in December 1998. The third will be approved in early 1999. LMER will submit an authorization agreement for Building 3019 during September 1999.

Oakland Operations Office. The Oakland Operations Office has incorporated safety management-related DEAR clauses in all of its laboratory contracts. Both the Stanford Linear Accelerator Center's accelerator facility and the E.O. Lawrence Berkeley National Laboratory (LBNL) have completed the Phase I verifications and are proceeding with validation of integrated safety management at their sites. The Lawrence Livermore National Laboratory (LLNL) will have completed the Phase I portion of ISM by the end of May 1999, and anticipates Phase II verification activities by the end of the CY 1999. 
Operations at Oakland laboratories are being performed using the core functions and principles of Integrated Safety Management as outlined in DOE Policy P-450.4, Safety Management.

The Oakland Operations Office has conducted its operations based upon these principles for over a year, while completing the documentation of its program and implementing corrective actions that have been identified in the process. All of Oakland's contractors have been made aware of the importance the Department places on safety in the workplace and were in the forefront in adopting the DEAR clauses implementing Integrated Safety Management into their contracts.

Ohio Field Office. Considerable progress in implementing Integrated Safety Management was made by the sites under the aegis of the Ohio Field Office during 1998. A combined Phase I and II verification was performed at the West Valley Demonstration Project (WVDP) in November 1998. The results of this verification included a recommendation that the Ohio Field Office Manager approve the WVDP Safety Management System Description as written, as well as a determination that Integrated Safety Management was being implemented successfully at WVDP. A similar combined Phase I and II verification has been scheduled at the Fernald Environmental Management Project (FEMP) for March 1999.

Efforts to resolve issues related to Integrated Safety Management implementation at the Miamisburg Environmental Management Project (MEMP) remain one of the highest priorities of the Ohio Field Office. A comprehensive corrective action plan, written in response to a May 1998 evaluation by the Department's Office of Oversight, was developed and approved at the MEMP. Completion of these corrective actions is the next key milestone in the implementation of Integrated Safety Management at the MEMP.

Richland Operations Office. Significant progress in implementing Integrated Safety Management at the Hanford site has been realized in the past year. During 1998, the final versions of the DEAR clauses were included in the Environmental Restoration Contract (ERC) and the Project Hanford Management Contract (PHMC). The DEAR clauses were incorporated in the Pacific Northwest National Laboratory (PNNL) contract in 1997. Substantially similar requirements have been incorporated into the recently awarded BNFL privatization contract. Three Authorization Agreements were prepared and approved during 1998: K Basins, TWRS, and the Radiochemical Processing Laboratory, with a fourth approval expected in January 1999 for the Reduction Oxidation (REDOX) facility. 
Three Integrated Safety Management verifications were performed at Hanford during 1998. In January, a Phase I verification of the $\mathrm{K}$ Basins was performed. This was the first ISMS verification at Hanford, and the results were mixed. The conclusion of the verification team was that the contractor's approach to implementation was basically sound, but too many corrective actions remained open to declare the Phase I verification complete. Nonetheless, the review was valuable as a learning experience, and helped Richland Operations Office prepare for subsequent verifications. In June, a combined Phase I/II verification of PNNL was performed. This verification involved several firsts - the first verification of a national laboratory, the first combined Phase I/II verification, and the first review utilizing an electronic pre-visit and orientation. The Review Team concluded that the PNNL approach was sound, and that a solid, functioning safety management system was in place at PNNL. In October 1998, corrective actions identified from the review were completed, and the PNNL System Description was approved. A Phase I verification of the Tank Waste Remediation System (TWRS) Safety Management System was performed Sept. 28-Oct. 8, 1998. Although some weaknesses were identified, the Verification Team concluded that the majority of the review criteria were met. Readiness for Phase II verification is currently targeted for July 1999. In October 1998, the Environmental Restoration Contractor submitted its safety management system description document to the Richland Operations Office for review.

A Phase I verification of the PHMC, as well as five (5) facility Phase II verifications, are currently scheduled for 1999 . The number of verifications planned represents a challenge to Richland Operations Office in terms of resources, but also reflects the progress being achieved in implementing Integrated Safety Management at Hanford.

Rocky Flats Field Office. An integrated safety management system description addressing all Rocky Flats Environmental Technology Site operations was provided to the Rocky Flats Field Office in March 1997. Combined Phase I and II verifications for Buildings 371 and 664 began in December 1997 and were completed in January 1998. Upon completion of required improvements, the integrated safety management system and associated integrated safety management implementation plan were approved by the Department on March 19, 1998. The site integrating contractor, Kaiser Hill, and its principal subcontractors completed the implementation plan and began institutionalizing Phase II verifications into the readiness determination process. This institutionalization supports the activity-based approach to closure used at Rocky Flats. All activities ongoing at Rocky Flats will be controlled by formal authorization agreements by January 1999. The standard integrated safety management-related DEAR clauses were incorporated into the Kaiser Hill contract in August 1998. 
Savannah River Operations Office. The safety management system description document, developed by the site contractor, Westinghouse Savannah River Company (WSRC), was incorporated into the site management and operations contract. Improvement actions from the Phase I integrated safety management system verification review, conducted in the Fall of 1997, were completed. In June 1998, a second Phase II review was conducted as an oversight of the contractor independent review of one facility and an associated modification project. The review confirmed that Integrated Safety Management as implemented is consistent with departmental policy. Actions required from this latter review are nearing completion. WSRC has developed a methodology and the procedures necessary to continue performing similar independent verification reviews of integrated safety management system implementation in other facilities and functional programs on the site. Authorization agreements were completed and signed for the last two of the designated nuclear facilities on site, bringing the total number of authorization agreements to 13 . A multi-course training program in integrated safety management principles and functions was developed and delivered to a significant portion of the site workforce using a graded approach. The Savannah River Operations Office has instituted an Integrated Safety Management team with representatives from the line and support organizations to continue further program enhancement and implementation. A contractor senior management steering committee was also instituted to provide strategic guidance and leadership to integrated safety management implementation. A strategic plan for enhancing this implementation was prepared and is being implemented.

\section{B. Improving Federal Technical Capability}

In response to the Board's original recommendation, the Department initiated a significant effort aimed at improving its overall technical capability. Despite substantial progress, Department-wide implementation of commitments aimed at improving technical capability was not fully institutionalized. Additionally, some commitments made in the original Implementation Plan were found to be unworkable or to provide little value given the changed staffing environment in the Department associated with workforce restructuring and downsizing. In its April 2, 1997, letter the Board suggested that the Department revise the Implementation Plan to reflect current issues and initiatives to address them. The Secretary submitted the Revised Implementation Plan for Improving DOE Technical Capability in Defense Nuclear Facilities Programs to the Board on May 5, 1998, and the Board accepted the revised Plan on June 1, 1998.

The Department's approach in the revised Implementation Plan differs from that in the original Implementation Plan. The original 93-3 implementation Plan dealt with both federal and contractor employees. In revising the Implementation Plan, the Department 
determined that the Integrated Safety Management process was sufficient to ensure that contractor employees were technically competent to manage and operate the Department's defense nuclear facilities. The revised Implementation Plan focuses on federal technical employees with defense nuclear facilities safety responsibility.

The Department of Energy is committed to developing and maintaining a technically competent workforce to accomplish its missions in a safe and efficient manner. Under the revised Implementation Plan this will be accomplished through the Federal Technical Capability Program. The Federal Technical Capability Program provides for the recruitment, deployment, development and retention of federal personnel with the demonstrated technical capability to safely accomplish the Department's missions and responsibilities. The program is specifically applicable to those offices and organizations performing functions related to the safe operation of defense nuclear facilities. Other organizations within the Department may apply elements of the program on an optional basis.

The Deputy Secretary is a strong advocate for the Federal Technical Capability Program. The principles of the Program are:

- As stated in the Department's Integrated Safety Management Guiding Principles: federal personnel possess the experience, knowledge, skills, and abilities that are necessary to discharge their safety responsibilities;

- Line managers are accountable and have the responsibility, authority, and flexibility to achieve and maintain technical excellence;

- $\quad$ Supporting organizations (personnel, training, contracts, finance, etc.) recognize line managers as customers and effectively support them in achieving and maintaining technical capabilities; and,

- An integrated corporate approach is required to assure that necessary technical capabilities and resources are available to meet the overall needs of the Department's defense nuclear facility missions.

The Federal Technical Capability Program consists of four primary functions. These functions are interrelated and use of only one or two of the functions will not ensure that an organization achieves its technical capability goals. For the Federal Technical Capability Program to succeed, all of the following functions must be effectively implemented. 


\section{Annual Report to Congress}

Executive Commitment and Line Management Ownership: This function includes establishing policies and procedures, assigning accountability, providing program direction, monitoring, and continuous improvement.

Recruiting and Deploying Technically Capable Personnel: This function includes career path planning, succession planning, defining position responsibilities, and filling technical positions with high-quality technical personnel.

Developing and Documenting Technically Capable Personnel: This function includes baselining existing technical capabilities and implementing developmental improvement programs.

Retaining Critical Technical Skills: This function includes career path planning, succession planning, performance reviews, promotions, and rewards.

Substantial progress was made in 1998 in implementing the Federal Technical Capability Program. Some of the more significant program accomplishments are listed below.

The Federal Technical Capability Panel (Panel) was established. The Panel consists of senior line managers who have been designated as Agents to represent Headquarters and Field Offices with defense nuclear facility responsibilities. The Panel reports to the Deputy Secretary and is responsible for overseeing and resolving issues affecting the Department's Federal Technical Capability Program, the Department's Senior Technical Safety Manager (STSM) Program, periodic assessments of the effectiveness of the Federal Technical Capability Program using internal and external experts, and providing recommendations to senior Departmental officials regarding the improvement of DOE technical capability.

A workforce analysis and staffing plan were completed by the organizations with defense nuclear facilities safety responsibility. The analyses identified critical technical skills that must be maintained to assure safe operations of defense nuclear facilities. Existing shortages and plans to deal with the shortages in the near-term were identified. The analyses are being used as part of the strategy to reduce downsizing effects on technical capabilities and as a basis for recruitment and development programs. The initial analysis resulted in the identification of approximately 740 positions across the Department that represent critical technical capabilities, including 175 Senior Technical Safety Managers and 201 Facility Representatives. Administrative actions were taken to reduce the potential impact of further downsizing on nearly all of these positions. 
Policies and procedures to preserve Facility Representative and other critical technical capabilities were developed and are being implemented. These policies and procedures will help ensure that critical technical capabilities are preserved during times of downsizing or increased attrition. Additionally, the Federal Technical Capability Policy, which implements and institutionalizes the Federal Technical Capability Program, was approved and signed by the Secretary. The Guide entitled RECRUITING, HIRING AND RETAINING HIGH QUALITY TECHNICAL STAFF: A Manager's Guide to Administrative Flexibilities was reviewed, revised and issued through the Department's directives system. Workshops on administrative flexibilities for recruiting, hiring and retaining high quality technical staff were conducted in the field and at headquarters by Panel agents.

The Technical Qualification Program (TQP) is undergoing revision. Phase I Assessments were conducted by all organizations implementing the program. The assessments were conducted by teams of line technical personnel and training personnel using formal written guidance issued by the Federal Technical Capability Panel. The assessment reports underwent a peer review process by the Panel members to ensure that the assessments met the intent of both the guidance and the Implementation Plan. The Phase I assessments formed the basis for the revised Technical Qualification Program Plans that will be implemented in 1999.

The Senior Technical Safety Manager (STSM) program is being implemented by the Department under the oversight of the Federal Technical Capability Panel. The STSM positions constitute the unbroken line of safety management authority and responsibility within the Department. A Senior Technical Safety Manager, usually at the Senior Executive Service or GS/GM-15 level, is assigned the direct responsibility to manage technical programs or provide direction, guidance, or evaluation of technical activities impacting the safe operation of defense nuclear facilities. STSMs must be technically competent as well as good managers. The Panel concurred with a revision to the list of STSMs in 1998 and will periodically review the qualification status of STSMs.

\section{Stabilization of Excess Nuclear Materials}

In February 1995, the Department established a program and plan for expediting remediation and stabilization of excess nuclear materials into safe, stable states for interim and long-term storage pending ultimate disposition. The halt in materials production for nuclear weapons froze the manufacturing pipeline in an intermediate state that was not optimal for long-term storage. Specifically, certain liquids and solids containing fissile materials and other radioactive substances located in spent fuel storage 
pools, reactor basins, reprocessing canyons, and various other facilities once used for processing and weapons manufacture needed to be stabilized.

Stabilization efforts were grouped by material types to take advantage of synergies. Six major categories of excess nuclear materials were identified: plutonium solutions, plutonium metals and oxides, plutonium residues and mixed oxides, special isotopes, certain uranium, and spent nuclear fuel. To date, the majority of high risk materials have in fact been stabilized, specifically:

- $\quad$ All known plutonium metal in direct contact with plastic has been repackaged.

- The largest volumes of plutonium solutions have been stabilized.

- $\quad$ Significant progress has been achieved in stabilizing high risk spent fuel and spent fuel storage facilities.

As the remaining high risk material stabilization activities continue to be pursued, other activities are focusing on managing the stabilization of more difficult, diverse material groups such as plutonium residues.

The Nuclear Materials Stabilization Task Group, established in February 1995 and renamed the Nuclear Materials Stewardship Program Office in 1998, integrates the Department's programs for stabilizing excess nuclear material to achieve safe, stable states for interim and long-term storage pending ultimate disposition. This office has established an integrated, complex-wide program for managing nuclear materials stabilization activities. To date, stabilization activities have been addressed complexwide in the following areas:

- Developing integrated Department-wide approaches to stabilization issues;

- Evaluating facility stabilization capabilities;

- $\quad$ Preparing facilities to support spent fuel and nuclear material removal and consolidation for long term storage; and

- Procuring standardized equipment to support plutonium oxide stabilization and packaging for long-term storage.

During 1988 the Department carefully reexamined the activities described in its 94-1 Implementation Plan and prepared a comprehensive revision of that document. The revision describes the accomplishments to date, the remaining actions needed to propose closure of the Recommendation, the revised plans to complete those actions, and the risk impacts of delays which have occurred in accomplishing the original stabilization plans. The revised plan was approved by the Secretary of Energy on December 28, 1998, and forwarded to the Board. 
In addition, the following activities were accomplished during 1998 to improve the Department's ability to accomplish the requirements during the remaining stabilization phase of the 94-1 activities.

\section{Studies/Special Assessments}

A special assessment, the Nuclear Materials Processing and Needs Assessment, was initiated in August, 1997, to identify whether any additional nuclear materials may require the Savannah River Site canyon facilities for stabilization or preparation for disposition prior to canyon decommissioning. This effort is focused on defining the most desirable technical pathways to the acceptable material end-states using efficiency, cost, waste, facility capabilities, and worker and public safety as performance measures. Completion is expected in early 1999.

\section{Nuclear Materials Integration}

The ongoing Nuclear Material Integration (NMI) Project is developing integrated, technically-based, life-cycle material management plans for all nuclear materials of interest to EM that will subsequently be incorporated into the Master Materials Management Plan (MMMP). The MMMP will support the reduction of overall environmental, safety, and health risks, as well as costs. It will include all materials currently belonging to the Office of Environmental Management (EM), those belonging to other programs but located at EM facilities or sites, and materials expected to be transferred to EM from other programs by 2015 . The materials will include:

- $\quad$ All forms of transuranic isotopes including mixed oxides;

- All forms of uranium and thorium; and

- All other isotopes and nuclear materials including sources and standards.

Specific objectives of the NMI are to define the inventory of all nuclear materials excess to national security or beneficial uses; identify and evaluate baseline disposition paths for the inventoried nuclear materials; identify material integration opportunities and alternative disposition paths to optimize the management of nuclear material; integrate Department-wide analyses of mortgage reduction opportunities; link the material disposition plans to the annual Defense Programs sponsored Nuclear Materials Inventory Assessment; and finally, to produce the Master Materials Management Plan, which will include detailed material-specific management plans with links to additional topical plans such as stewardship, research and development, transportation, and facilities which will be developed. 


\section{Annual Report to Congress}

The materials covered by the 94-1 implementation plan are a subset of the materials to be covered by the MMMP. As the breadth of individual materials management plans is extended to cover management of the materials through disposition, the activities detailed in the 94-1 implementation plan will form a subset of the actions prerequisite to the disposal or disposition of the 94-1 materials. To facilitate the identification of those activities and materials related to 94-1, the MMMP will separate those materials into distinct disposition paths and indicate the point on each disposition path where stabilization is achieved. In this way accountability for the specific actions required to remediate the safety-related concerns of 94-1 will be maintained. Disposition maps for the 94-1 materials will be included as part of the material management plans.

Environmental Impact Statement on Management of Certain Plutonium Residues and Scrub Alloy Stored at the Rocky Flats Environmental Technology Site

The Rocky Flats plutonium residues and scrub alloy will either be prepared for disposal in the Waste Isolation Pilot Plant or be shipped to the Savannah River Site for processing prior to disposition. The Environmental Impact Statement on Management of Certain Plutonium Residues and Scrub Alloy Stored at the Rocky Flats Environmental Technology Site was prepared to evaluate alternatives for management of these materials, thus providing the basis for determining whether they should be processed to allow their disposal or other disposition.

\section{Plutonium Storage Standard}

Working in cooperation with the Offices of Defense Programs, Environmental Management, and Fissile Materials Disposition, the Nuclear Materials Stewardship Project Office (NMSPO) at the Albuquerque Operations Office is sponsoring the development of a revision to the technical standard for storage of plutonium, DOE-STD3013-96, "Criteria for Preparing and Packaging Plutonium Metals and Oxides for Long Term Storage." The existing standard applies to metals and oxides with at least $50 \%$ plutonium, which were the materials in greatest need of storage criteria. However, Environmental Management's continued progress in cleaning up Department sites that formerly produced or processed nuclear materials has created a need for a standard that would address materials with lower plutonium content. The revised standard will address stabilization, packaging, and storage of such materials.

The population of materials that must be addressed by the revised standard is large and diverse. Consequently, it is important that a comprehensive and systematic approach be taken in its development. Toward that end, a "systems engineering" approach is being used. Major and subordinate functions have been identified, and requirements for those 
functions have been identified. The revised standard is expected to stress quantitative functional requirements, allowing the sites flexibility in selection of processes to meet those requirements.

Work on the revised standard (DOE technical standard project number PACK-0011) began in January 1998. A core team was assembled to collect the technical information to support the new standard. A working group was convened in March to begin drafting the standard. That work is still underway. Further progress on the specific language in the standard awaits completion of several key research projects. The present goal is to have a draft standard ready for coordination by the spring of 1999 so that a final standard can be available by the summer of 1999 .

\section{Research and Development}

Research and development activities continued in 1998 to provide the necessary stabilization technologies and technical basis for long-term storage. Los Alamos National Laboratory, the lead Laboratory for plutonium research and development in support of 94-1, managed 20 technical projects in Fiscal Year 1998. Of the 20 technical projects, three were performed at other Department laboratories or universities throughout the country. At the end of Fiscal Year 1998, the program completed $78 \%$ of the tasks and milestones originally established at the start of the FY. This included several schedule revisions and changes in work scope as the result of changes in complex-wide baselines in support of 94-1 commitments. Also, the program provided technical support to the Nuclear Materials Stewardship Program Office at DOEAlbuquerque.

The Materials Identification and Surveillance Project completed studies on the Hanford and Rocky Flats samples. These samples represent materials that the sites have identified for stabilization and packaging for long-term storage. The analytical data generated by these materials, as well as materials at Los Alamos, form the technical basis for long-term storage. The data support proposed changes in the long-term storage standard, DOE-STD-3013-96. In addition, experiments were performed on the alphabeta phase transformation. The Core Technology Program has further advanced our basic science understanding of material storage. The program has explored the basic science aspects of the reactions of water with plutonium and uranium metal and oxides, the recombination reactions of hydrogen and oxygen on oxide surfaces and within a long-term storage container, and the nature of stabilized materials using EXAFS and XANES experiments. All of the work is pushing forward our understanding of plutonium science at the macroscopic, as well as the microscopic level. 
For FY 1998, the program completed work to support salt distillation, the vitrification of ash and graphite fines, and the wash and dry treatment process for combustibles. A flowsheet for the processing of fluorides by aqueous precipitation was demonstrated for Rocky Flats, and this work will continue in FY 1999. The pyrolysis team has delivered the pyrolysis with silent discharge plasma design and test package, closing out the development of this method. Work continued for Hanford to support pyrolysis with catalytic oxidation, which will result in the delivery of two units in FY 1999.

\section{Criticality Safety}

Criticality safety is protection from the consequences of a criticality accident, preferably by prevention of the accident. Criticality safety encompasses procedures, training, and other precautions in addition to physical protection. Where operations involve significant quantities of fissile material, accidental criticality is a hazard for which analysis must be performed and controls must be identified and implemented. The Department recognizes that identifying and analyzing credible accident scenarios and implementing appropriate controls to prevent or mitigate an accidental criticality must involve an efficient process that does not use excessive resources and that allows work to be accomplished in a timely manner.

The Department's recent criticality safety activities were initiated under the Nuclear Criticality Predictability Program (commenced in 1996) and are now subsumed under the implementation plan for Board recommendation 97-2. In the Nuclear Criticality Predictability Program, the Department established an infrastructure to address nuclear criticality predictability needs. The five elements of this program - nuclear data, analytical methods, experiments, benchmarking, and training - preserve criticality experiment capabilities and provide data vital to current and future Departmental missions. The Department has since expanded this program to include two more elements: nuclear criticality information preservation \& dissemination and extending applicable ranges of bounding curves and data. These seven program elements are described in the Nuclear Criticality Safety Program five-year plan issued in June 1998.

The five-year plan was developed as part of the activities under the Department's implementation plan for Board recommendation 97-2. Other implementation plan activities include:

- Improving the technical knowledge of criticality safety personnel. This will be accomplished by incorporating best practices, developing a technical qualification standard for federal criticality safety staff, identifying exceptional 
criticality safety curricula offered at institutions outside the Department, and developing additional curricula as needed to fill identified gaps.

- Improving the availability and use of criticality safety information and guidance. A new headquarters criticality safety web site has been developed (http://tis.eh.doe.gov/criticality/index.html) and the criticality safety web site at Lawrence Livermore National Laboratory (http://ncsc.llnl.gov:8080/) has been designated as the lead technical web site for the Department. Enhancements have been completed at the Los Alamos National Laboratory criticality safety web site (http://orion.lanl.gov/ncs/index.htm) to include information from the Criticality Safety Information Resource Center.

- Verifying that sites having fissile material operations have appropriately considered criticality safety in the work planning process. Assessments have been completed at the following sites: Savannah River Site, Hanford Site, Rocky Flats, Oak Ridge Y-12, Argonne National Laboratory, New Brunswick National Laboratory, Idaho National Engineering and Environmental Laboratory.

In addition to these improvements, a cross-organizational Memorandum of Understanding for Funding Criticality Safety Activities was approved by the affected Secretarial Officers and signed by the Deputy Secretary on August 14, 1998. This MOU formalizes the budget development and execution process for criticality safety activities by explicitly defining the roles and responsibilities between the 97-2 responsible manager, affected program offices, and the Chief Financial Officer. 


\section{IMPLEMENTATION OF BOARD RECOMMENDATIONS}

\section{A. Recommendation Closures}

The entire process of opening, acknowledging, addressing, resolving, and closing Board recommendations provides a model for safety oversight processes used in various organizations and at various levels throughout the Department's nuclear complex. The manner in which the Department management acknowledges, addresses, and resolves Board safety issues provides an example throughout the Department. Similarly, the manner in which the Board opens safety issues, evaluates resolution approaches, monitors implementation, and ultimately closes safety issues also sets a tone for Department and contractor safety oversight organizations. To be effective, these processes must be understandable and predictable.

When a safety issue is identified by an oversight organization for special attention, there is a tendency to reduce line management control over the resolution of the issue by providing additional management direction and organizational support and advice. For example, additional Department headquarters personnel typically get involved and provide direction to the field for implementation. This can conflict with the guiding safety principle that safety is best served through strong line management ownership which integrates safety into normal work processes at the working level. The more quickly that ownership of safety issues is fully integrated into normal line management functions at the working level, the better for safety.

Safety oversight processes which periodically open safety issues and then routinely close them upon substantial resolution serve safety by supporting line management's responsibility for and ownership of safety issues. A routine and orderly process for opening, resolving, and closing safety issues serves safety by reinforcing the concepts of openness to improvement opportunities, addressing safety issues when identified, and strong line management ownership of safety. Similarly, closure of Board recommendations is beneficial to safety when the fundamental safety issues are acknowledged and addressed, the resolution approach is appropriate, the resolution is substantially on target and achieving results, and the organizations and systems are sufficiently mature to integrate continued implementation into ongoing activities. A predictable process for opening, resolving, and closing Board recommendations is also consistent with the original Congressional intent for completion of implementation plans within a relatively short period of time, such as one year. Continued oversight and monitoring is expected on closed Board recommendations to ensure that safety programs and resolutions continue to be implemented as needed. If implementation were to degrade, the safety issue would demand renewed management attention. 
Department activities culminating in 1998 led to proposed closure of the following Board recommendation:

- $\quad$ Recommendation 92-4, Multi-Function Waste Tank Facility at the Hanford Site

\section{Recommendation 92-4 - Multi-Function Waste Tank Facility at the Hanford Site}

The primary focus of Board recommendation 92-4 was the Tank Waste Remediation System (TWRS) Multi-Function Waste Tank Facility (MWTF) project at the Hanford Site. The recommendation identified three areas of concern: 1) project management structure, 2) design bases (systems engineering) for MWTF, and 3) technical and managerial competence. In developing an implementation plan to address these issues, the Department expanded the scope of its response to apply an integrated systems approach to define, plan, control, and execute the overall Hanford mission. While implementing this approach, the Department reevaluated the need for the MWTF project, canceled the project, and altered other TWRS projects. The Department completed thirty-eight commitments, including all program management and Site systems engineering commitments, in the first implementation plan.

During calendar year 1997, the Department revised the implementation plan to demonstrate institutionalization of systems engineering in the current TWRS Program. The revised implementation plan identified specific systems engineering deliverables within TWRS to demonstrate the implementation of systems engineering at the project level, and focused primarily upon three key areas:

- Implementing and institutionalizing a process for developing TWRS technical design bases

- Integrating TWRS projects with the activity of a private vitrification contractor, and

- Improving the technical capability of TWRS federal staff.

Commitments addressing the capability of TWRS federal staff were completed in 1997. Significant accomplishments occurred in 1998 in the remaining two key areas.

\section{TWRS Technical Design Bases}

TWRS previously initiated a process for translating Technical Baseline information into project design specifications. On the Initial Tank Retrieval System Project, this process was used to demonstrate the capability to produce Technical Requirements Specifications. These define a graded technical baseline for the double-shell tanks, 
including a comparison of the revised specifications to baseline project specifications. TWRS also developed a methodology for periodically assessing progress in applying a graded approach for implementing systems engineering on TWRS projects. The methodology was successfully demonstrated by assessing the systems engineering processes in place on the TWRS Immobilized Low-Activity Waste Interim Storage Project.

\section{Integration with Vitrification Activity}

Commitments in the implementation plan systematically addressed the interface between the TWRS project and the "privatized" scope of work to vitrify tank wastes. TWRS produced representative samples of Interface Control Documents which systematically identify interface points between the private vitrification vendor and other Hanford projects. In addition, TWRS established criteria to assess integration of the vitrification vendor's Authorization Agreements with requirements established within other Authorization Agreements and performed an evaluation of the adequacy of technical and safety deliverables required of the vitrification vendor.

This implementation plan required more than one year to complete due to the magnitude of applying systems engineering principles to projects at the Hanford Site. The final implementation plan deliverable was completed and provided to the Board in July 1998 and the Department proposed closure of the Recommendation in a December 16, 1998, letter to the Board.

\section{B. New Recommendations and Implementation Plans}

In 1998 the Department accepted two new recommendations received from the Board:

- Recommendation 98-2, Safety Management at the Pantex Plant

- Recommendation 98-1, Resolution of DOE Internal Oversight Findings

The Department is developing implementation plans for these two recommendations, with issuance expected in the spring of 1999. These plans will define the Department's approach and schedule to resolve the associated safety issues. 
Recommendation 98-2, Safety Management at the Pantex Plant

The Board issued recommendation 98-2, which deals with the safety management at the Pantex Plant in Amarillo, Texas, on September 30, 1998. The recommendation contains information which is classified.

At an unclassified level, the recommendation deals with opportunities that exist to strengthen and simplify the process by which the Department designs and develops activities at the Pantex Plant and independently evaluates the safety of those operations. The Board believes that the Department should take action to improve these processes.

The Secretary accepted the recommendation on November 20, 1998. The Department is currently preparing the implementation plan under the leadership of the Office of the Assistant Secretary for Defense Programs. The implementation plan is due to the Board in the spring of 1999.

\section{Recommendation 98-1, Resolution of DOE Internal Oversight Findings}

On September 28, 1998, the Board issued recommendation 98-1, which deals with the need for a systematic process for the disposition and resolution of the findings of the Department's internal, independent oversight organization. The recommendation identifies specific weaknesses in the existing finding resolution process, and recommends that the Department address several elements to improve the process, including: roles and responsibilities, issue/dispute resolution process, senior management involvement, content of corrective action plans, tracking, reporting, and verification approaches.

The Secretary accepted the recommendation on November 20, 1998. The Department is currently preparing the implementation plan under the leadership of the Office of the Secretary. The implementation plan is due to the Board in the spring of 1999.

\section{Other Active Implementation Plans}

\section{Recommendation 97-2, Criticality Safety}

The Board issued recommendation 97-2 on May 19, 1997, addressing the effectiveness of criticality safety programs at defense nuclear facilities in the Department complex. This recommendation identified the need to ensure that criticality safety continues to be achieved efficiently in the Department's current and future operations. It represents a 
continuation and expansion of Board recommendation 93-2, Critical Experiment Capability.

The Department developed an implementation plan which outlines a comprehensive strategy to improve the efficiency of criticality safety programs within the Department. The key accomplishments related to recommendation 97-2 during 1998 were:

- The cross-organizational Nuclear Criticality Safety Program management team and criticality safety support group were established to manage the Department's criticality safety activities and help resolve present and future criticality safety issues.

- A Memorandum of Understanding for Funding Criticality Safety Activities was approved by the affected Secretarial Officers and signed by the Deputy Secretary on August 14, 1998. This memorandum formalizes the budget development and execution process for criticality safety activities by explicitly defining the roles and responsibilities of the 97-2 responsible manager, affected program offices, and the Chief Financial Officer.

A new headquarters criticality safety web site was developed (http://tis.eh.doe.gov/criticality/index.html), and the criticality safety web site at Lawrence Livermore National Laboratory (http://orion.lanl.gov/ncs/index.htm) was designated as the lead technical web site for the Department. Enhancements were completed at the Los Alamos National Laboratory criticality safety web site (http://ncsc.llnl.gov:8080/) to include information from the Criticality Safety Information Resource Center.

- Improvements were made to DOE-STD-3007-93 (Change 1), Guidelines for Preparing Criticality Safety Evaluations at Department of Energy Non-Reactor Nuclear Facilities, to include examples of using simplified analysis methods in criticality safety evaluations.

- $\quad$ Sites conducted assessments to verify that criticality safety is appropriately considered in the work planning process, consistent with principles of Integrated Safety Management. The following sites completed these assessments: Savannah River Site, Hanford Site, Rocky Flats, Oak Ridge Y-12, Argonne National Laboratory, New Brunswick National Laboratory, Idaho National Engineering and Environmental Laboratory. 


\section{Annual Report to Congress}

- An assessment was conducted to identify areas in which additional criticality safety training could be useful for criticality safety staff at field sites. Assessment results will be used as a basis for developing guidance for improving site-specific criticality safety training and qualification programs.

The Department's implementation plan represents an aggressive strategy for improving criticality safety programs to ensure efficient support of ongoing fissile material activities. However, the Department will require more than one year to implement this plan due to the magnitude and scope of the actions required to improve the Department's criticality safety program. The plan's final action, qualifying federal staff directly performing criticality safety oversight, is scheduled to be completed in December 1999.

\section{Recommendation 97-1, Safe Storage of Uranium-233}

The Board issued recommendation 97-1 which deals with the safe storage of unirradiated uranium-233 (U-233) bearing material on March 3, 1997. The recommendation had been preceded in February 1997 by a Board technical report entitled "Uranium-233 Storage Safety at Department of Energy Facilities." The report described the Board's perspective of the safety of U-233 stored at various sites in the Department's complex. This formed the basis for the Board's recommendations. The report also acknowledged the Department's Highly Enriched Uranium Vulnerability Assessment completed in August 1996. As a result of that assessment, the Department was aware of the legacy issues surrounding the storage of U-233 bearing material. The Department's assessors had come to many of the same conclusions as those described in the Board's technical report. At the time of issuance of recommendation $97-1$, the Department had initiated development of a plan describing the necessary corrective actions for the most significant vulnerabilities identified. The Department's Highly Enriched Uranium Vulnerability Management Plan was issued on June 13, 1997.

The Department has an inventory of approximately two metric tons of U-233 in many different forms stored under a variety of conditions throughout the complex. The majority is located at the Oak Ridge National Laboratory and the Idaho National Engineering and Environmental Laboratory, with much smaller quantities at Los Alamos National Laboratory and even smaller quantities at numerous other sites. The material exists in various forms, as oxides, metal, solutions, and fluorides.

The Secretary accepted the recommendation on April 25, 1997. In developing the implementation plan, the Department assessed the relevant safety issues in terms of the history of U-233. The primary safety issue being addressed is the lack of material 
characterization and uncertainty of storage conditions for U-233. The implementation plan was approved on September 29, 1997.

The Department is using a systems engineering approach to manage the implementation of this recommendation as well as to consider long term options for the U-233 inventory such as long term storage, disposition as excess material or possible beneficial use. During the year the Department made considerable progress by completing twelve commitments of the implementation plan for this recommendation. Some key activities completed in 1998 include:

- A study of long-term disposition alternatives for excess U-233.

- A Departmental standard for packaging and long term storage of U-233.

- A study to evaluate the best long term storage facility option.

- A document to provide guidance in determining what U-233 concentrations can be handled as waste.

- A document describing requirements for the U-233 Safe Storage System, a significant component of the systems engineering process.

- $\quad$ Site assessments of material packaging and storage conditions at INEEL, ORNL and LANL to ascertain the need for additional near term actions to remedy risks.

- A study of the Department's technical expertise available to the U-233 program.

- A study of small holdings at various sites within and outside the DOE complex for possible consolidation at a long term storage facility.

In addition to the above, the Department developed during 1998 a comprehensive, integrated multi-year plan, the Program Execution Plan (PEP), designed to complete resolution of safety concerns referenced by recommendation $97-1$ and provide a long term management strategy for disposition, beneficial use or other decision alternatives relative to the U-233 inventory. The plan is expected to be complete in early 1999. 
The PEP identifies near-term activities at major U-233 sites to meet the Department's safe storage commitments in response to recommendation 97-1. Some key activities for 1999 include:

- $\quad$ At INEEL - Inspect and characterize the condition of Light Water Breeder Reactor fuel pellets. Determine a long term storage option for unirradiated materials at CPP-749 and at the Radioactive Waste Management Complex.

- $\quad$ At ORNL - Begin Phase I inspection and repackaging operations for U-233 in Building 3019. Continue facility upgrades required for inspection and repackaging.

- At LANL - Move U-233 inventory from TA-18 to the Chemistry Metallurgical Research Facility. Prepare for shipment of excess U-233 materials to an offsite location.

The implementation plan for recommendation $97-1$ requires more than one year to implement due to the magnitude of actions required at multiple sites and across multiple organizations, as well as the need to systematically develop and execute the long term PEP. The final implementation plan deliverables are projected for completion in 1999.

\section{Recommendation 96-1, In-Tank Precipitation System at the Savannah River Site}

The Board issued recommendation 96-1 on August 14, 1996, to address concerns at the In-Tank Precipitation (ITP) facility related to potential generation and release of flammable benzene in the primary process tank. This recommendation identified the need for improved understanding of the mechanisms leading to the generation, retention, and release of benzene, and based on this understanding, evaluation of the adequacy of existing safety measures and development of additional safety measures as necessary.

ITP is the process step in the vitrification of unstable hazardous radioactive and chemical liquid wastes that precipitates the highly radioactive salt fraction of liquid high-level waste to allow for vitrification of the wastes by the Defense Waste Processing Facility. ITP began operations in September 1995, treating the first batch of high-level waste with sodium tetraphenylborate (TPB) to precipitate cesium, and sodium titanate (MST) to adsorb uranium, plutonium and strontium. Following several startup tests, slurry pumps were being operated on December 1,1995 , prior to sampling the tank, when benzene in quantities greater than expected was first observed. Since December 1995 , the Department has been performing analysis and testing to better understand the observed benzene phenomenon. 
Chemistry test program results have determined that TPB breaks down into intermediate products, producing benzene as each product decomposes. Certain waste components accelerate the decomposition reaction. Test results have indicated that benzene generation rates produced from decomposition reactions will cause benzene release rates to exceed the capacity of current plant hardware/systems. Not only does sodium TPB decompose, but potassium and cesium TPB can also decompose rapidly under certain conditions, threatening the ability to maintain the salt solution until prepared for vitrification processing at $\mathrm{DWPF}$.

The key accomplishments related to recommendation 96-1 during 1998 were:

- In January 1998, it was concluded that high benzene generation rates and precipitate solids instability would not support the ITP process as currently designed. As a result, ITP restart preparations were suspended pending the outcome of a system engineering evaluation of potential options for removing cesium from stored high level waste solutions.

- The following Implementation Plan deliverables were completed and issued to the Board in May 1998:

- Complete laboratory studies on catalytic decomposition of solid TPB

- Complete actual waste confirming studies

- Define the important benzene retention mechanisms

- Determine the capacity and distribution of benzene retention in tank 48 slurry

- Complete laboratory benzene release studies

- Document benzene release rates due to localized agitation caused by previous water or chemical additions

- A topical report summarizing the results of the ITP Chemistry Program, addressing the overall safety of the tetraphenylborate chemistry products remaining in the ITP process tanks, and identifying any outstanding 96-1 open items was completed in July 1998.

Any further action with regard to resolution of 96-1 issues was put on hold until the alternatives evaluation could be completed and a preferred alternative could be selected.

The Westinghouse Savannah River Company completed the alternatives evaluation in November 1998; however, DOE-SR has concluded that additional R\&D is required to address uncertainties associated with the final "short list" alternatives before a preferred alternative can be selected. It is expected that the additional $R \& D$ could take in excess 
of six months duration. No further action with regard to resolution of $96-1$ issues is planned until a preferred alternative is selected and it has been determined that the 96-1 issues are still valid.

\section{Recommendation 95-2, Integrated Safety Management}

Recommendation 95-2 called for: 1) an institutionalization process for ensuring environment, safety, and health requirements are met; 2) graded safety management plans for the conduct of operations; 3 ) a prioritized list of facilities based on hazards and importance; 4) direction and guidance for the safety management process; and 5) measures to ensure availability of technical expertise to implement the streamlined process effectively. The Department's April 1996 implementation plan describes the Department's approach for implementing these recommendations.

Key accomplishments for 1998 are summarized below:

- In 1998, a revision to the Department of Energy Acquisition Regulation (DEAR) which contain two clauses describing safety management system requirements for contractors were incorporated into all major management and operations (M\&O) contracts.

- The Department's FY 1998 Strategic Plan incorporated specific provisions and completion expectations for the institutionalization of integrated safety management and safety functions, responsibilities, and authorities documents.

- The Department promulgated Functions, Responsibilities, and Authorities Manuals (FRAMs) for the priority facilities' cognizant field and headquarters offices for use in July 1997, while the headquarters FRAM was officially promulgated in October 1997. These documents are being revised and updated based on experience gained through the use of these documents. The FRAM development and subsequent upgrading effort were necessary to ensure the emplacement of a solid, functioning, organizational infrastructure that now serves as the foundation for the Department's integrated safety management program.

- The Department has completed a revision to the Integrated Safety Management System (ISMS) Guide which comprehensively explains the Department's program and provides guidance to managers for system implementation at a variety of facilities and activities with diverse hazards and risks. Promulgation of the revised guide is projected for February 1999. 
- Considerable progress was achieved during 1998 in tailoring the implementation of safety management systems to the missions and needs of the particular sites and facilities.

- A draft Integrated Safety Management System Team Leader's Handbook was published in February 1998. This handbook explains the verification concepts in great detail and outlines the verification team leader and team member selection process.

- In 1998, the pace of verification reviews accelerated substantially, with verifications conducted at the following sites: Rocky Flats Environmental Technology Site, Hanford's K-Basin, Hanford's Tank Waste Remediation System, Oak Ridge's Y-12 Plant, Waste Isolation Pilot Plant, Pacific Northwest National Laboratory, Stanford Linear Accelerator Center, West Valley Demonstration Project, Pantex Plant, and Sandia National Laboratory.

- Two very successful Integrated Safety Management lessons learned workshops were conducted during 1998. Line managers and environment, safety and health officials from every Department entity across the complex were represented at each workshop, with approximately 350 and 420 personnel participating in the respective workshops. These workshops were useful in providing forums for sharing the lessons learned from implementing tailored integrated safety management systems across the complex.

- As of December 1998, the Department has conducted sufficient verifications and lessons learned sharing workshops to conclude that sufficient top-level infrastructure supporting integrated safety. management is now in place at all major sites and facilities.

- In June 1998, the Department prepared an action plan outlining its program for assessing work performance and tracking related to corrective actions. The Department recognized that these feedback and continuous improvement activities are an essential feature of an integrated safety management system and is committed to strengthening the use of feedback and operating experience to improve the safety of its operations.

The Department has made significant strides in implementing integrated safety management. Effective program integration and culture change continue to remain the focus of the Department's attention as implementation expands. As reported in the 1996 Annual Report to Congress, the Department's 95-2 implementation plan will require 


\section{Annual Report to Congress}

more than one year to implement due to the magnitude of the fundamental changes involved in the Department's approach to safety management. Although the framework for safety management is now largely in place, full implementation will be an extensive effort extending beyond 1998.

\section{Recommendation 95-1, Improved Safety of Cylinders Containing Depleted Uranium}

Recommendation 95-1 identifies the Board's concerns about the storage conditions and plans for long-term management of depleted uranium hexafluoride at Portsmouth, Ohio; Paducah, Kentucky; and Oak Ridge, Tennessee. The Department is storing nearly 700,000 metric tons of depleted uranium hexafluoride in solid form in nearly: 56,000 steel cylinders at the three gaseous diffusion plants. The recommendation calls for 1) repainting or recoating the cylinders, 2) implementing protective measures to prevent future damage or corrosion, and 3) considering a study on alternative chemical forms for the long-term storage of the depleted uranium.

The Department had initiated a program in 1992 to ensure the safety of the long-term storage of depleted uranium hexafluoride. The Department's response to the Board's recommendation was to improve the cylinder management program through a systems engineering approach to risk management. These improvements were developed and instituted concurrently with program activities that were underway. The Department also evaluated, in the safety analysis reports, the adequacy of the safety basis for continued cylinder management, and considered the need for a study on alternative chemical forms for long-term storage of the depleted uranium. After that evaluation, the Department informed the Board that the safety basis was adequate for continued storage, and that such a study was, therefore, unnecessary. The steps in the systems engineering approach to risk management were completed with the final implementation plan commitments delivered on schedule in 1997. Significant accomplishments in 1998 are:

- A 460,000 sq. ft. concrete storage yard was completed at Paducah early in 1998. This construction is part of on-going improvements for the storage of cylinders.

- A request for proposals was released in October 1997 to continue painting cylinders at both Paducah and Oak Ridge in 1998. A subcontract was awarded and 1600 cylinders were painted during the 1998 Fiscal Year.

- A systems engineering requirements analysis was completed that determined the technical rationale for continued concrete yard construction. 
- The respacing of cylinders at Portsmouth was completed in 1998. This activity was necessary to enable the program personnel to access cylinders for periodic inspections.

- The Cylinder Program was successfully transitioned to a new Department prime contract with the Bechtel Jacobs Company LLC.

- In response to Public Law 105-204, the Department began preparing a plan to construct and operate chemical conversion facilities at the Paducah and Portsmouth Gaseous Diffusion Plants. This plan will continue to address the Board's concerns with long-term management of the inventory.

- As a result of the privatization of the United States Enrichment Corporation (USEC), the Department accepted approximately 9000 additional cylinders containing depleted uranium. The agreement to accept these cylinders was based on receiving USEC funding to place these cylinders in a configuration compliant with the systems engineering approach implemented in response to recommendation 95-1.

Maintaining the cylinders and improving their storage condition is a multi-year activity. The systems engineering documents delivered to the Board require the construction of additional new cylinder yards, the reconstruction of additional existing cylinder yards, the restacking of cylinders to facilitate inspection and reduce exposure to moisture, and the recoating of cylinders to reduce the rate of external corrosion. Major elements of these tasks will be completed after the year 2000. Some elements, such as inspection, surveillance, yard maintenance, recoating and spot-painting, will continue as long as the Department stores cylinders containing the depleted uranium hexafluoride. The Department continued painting cylinders in 1998 and also implemented additional controls to prevent or mitigate a cylinder handler fire scenario identified in the final safety analysis reports.

The Department's 95-1 implementation plan required more than one year to complete due to the magnitude of the Department's actions and the deliberate, systems approach employed to establish and implement handling and storage solutions. The final commitment of this implementation plan (approved safety analysis reports on the technical adequacy of depleted uranium hexafluoride storage) was completed in March 1997. The Department continues to update the systems engineering documents that govern cylinder management activities. In particular, the Cylinder Management Program Plan was updated to reflect revised FY 1998 and forecasted budgets and accomplishments. The Board has kept the recommendation open as they continue to 


\section{Annual Report to Congress}

monitor progress on cylinder painting and the safety management of the depleted uranium cylinders.

\section{Recommendation 94-5, Integration of Department of Energy Safety Rules, Orders, and Other Requirements}

This recommendation suggests that further Department actions were needed to ensure there is no relaxation of plans made to achieve compliance with requirements of Department safety orders while new, streamlined orders were issued and proposed safety rules were under development. In September of 1996, the Board concluded that the orders of interest to the Board were successfully mapped to revised Department orders and proposed safety rules. Other major accomplishments included the completion of crosswalks of requirements from the old safety orders to the new safety orders, and the development of policy statements P 450.2, "Implementation and Compliance with Environment, Safety and Health Requirements," and P 410.1, "Promulgating Nuclear Safety Requirements."

The key accomplishments related to recommendation 94-5 during 1998 were:

- The Departmental Functions, Responsibilities and Authorities Manual (Corporate level) (FRAM) including the program and field office level FRAMs are being updated and should be reissued by early 1999. The purpose of the corporate-level and lower-tier documents is to ensure Department functions, responsibilities, and authorities for safety management are clearly defined.

- The Department Order and Manual 251.1, "Directive System," was issued on January 30, 1998. These documents establish the framework and requirements for the development, coordination, and review of internal Department documents such as Policies, Orders, Notices, Manuals and Guides.

- The process of reviewing directives between the Board staff and the Department has been formalized to resolve technical and safety-related issues. After resolution of such issues, the following documents have been issued during 1998: Order 414.1 Quality Assurance, Order 430.1 Life Cycle Asset Management, Order 440.1A Worker Protection Management for DOE Federal and Contractor Employees, STD1128-98 Guide of Good Practices for Occupational Radiological Protection in Plutonium Facilities, STD-1 120-98 Integration of Environment, Safety, and Health into Facility Disposition Activities, and STD-1113-98 Radiological Safety Training for Uranium Facilities. 
The actions described in the Department's implementation plan are either completed or were constructively incorporated into the Department's safety management implementation plan. The Department's 95-2 implementation plan is the primary framework and driver for all aspects of programmatic safety management, including identification of safety standards and requirements, refinement of Federal roles and responsibilities for safety, and verifying effective safety management implementation. Recommendation 94-5 has clearly accomplished its primary objectives.

\section{Recommendation 94-4, Deficiencies in Criticality Safety at Oak Ridge Y-12 Plant}

Recommendation 94-4 summarizes the Board's concern with criticality safety and conduct of operations at the Y-12 Facility at Oak Ridge. The recommendation acknowledges that the Department and its contractor have taken steps to correct deficiencies, and encourages more aggressive and comprehensive management actions.

The 94-4 implementation plan presented a schedule of near-term actions to support the Y-12 resumption effort. The plan also presented a path of programmatic improvements to assure the achievement of an adequate level of safety at $Y-12$ over the long-term. The implementation plan includes assessments of the level of conduct of operations at $Y-12$, reviews of personnel training, and compliance evaluations on operational safety requirements, criticality safety analyses, and operating procedure controls. The Department is using operational readiness reviews and readiness assessments, conducted by senior technical managers augmented as necessary by independent experts, to ensure that needed program improvements and culture changes are institutionalized.

Significant accomplishments in 1998 include the following:

- Phase A of enriched uranium resumption was broken into two parts. Phase A1 dealing with casting, rolling, and forming operations, and Phase A2 which addresses Accountability Processes.

- Phase A1 resumed operations after the completion of a Department Operational Readiness Review and closure of pre-restart findings on July 20, 1998.

- An operational readiness review for Phase A2 was completed on November 18, 1998, and operations resumed on December 16, 1998.

- Quarterly reporting to the Board was discontinued, and annual status reports will be provided instead. 
The 94-4 implementation plan requires more than one year to implement due to the magnitude of the Department's actions involved and the required changes to the safety culture. The remaining implementation plan deliverables are those associated with resumption of the final primary mission area, enriched uranium operations, and annual reports. Enriched uranium operations are being resumed in two phases. Phase A resumption has been completed and Phase B (full metal recovery capability) is scheduled to resume operation in 1999. Enriched Uranium Operations is the most complex of the five missions areas and involves upgrade of the most requirements, criticality safety analyses, and operating procedures.

\section{Recommendation 94-3, Rocky Flats Seismic and Systems Safety}

Recommendation 94-3 focused the Department on assuring that Rocky Flats' large plutonium inventory is stored in a robustly safe facility. At the time of this recommendation there were uncertainties regarding the capacity of the intended storage facility to resist earthquakes. Rocky Flats is consolidating the site's plutonium into Building 371 pending off-site disposal.

The Department completed its implementation plan commitments to resolve safety questions and plan appropriate safety margin improvements in 1996. Because all actions to upgrade the safety of Building 371 were not then completed, efforts to continue them were managed under a formal Integrated Program Plan. That plan was subsequently revised on June 4, 1998. The revision provides for continuing upgrades until substantial progress in shipping plutonium materials off-site provides assurance that additional expenditures for site interim storage safety are not needed.

To date several sets of safety upgrades have been completed. During 1998, "priority" upgrades were finished, an improved safety authorization basis was implemented, and most of the safety upgrades relating to a revised safety analysis were completed. Meanwhile, arrangements for storage or disposal of Rocky Flats' plutonium at other sites continue. Implementation of additional safety margin upgrades to Building 371 may be discontinued if shipping milestones identified in the Integrated Program Plan are met. That may happen as early as 1999. 
1998 Annual Report to Congress

Recommendation 94-2, Conformance with Safety Standards at Low-Level Nuclear Waste and Disposal Sites

Recommendation 94-2 expressed the Board's concern that the Department's low-level waste management program had not kept pace with the evolution of commercial practices. The Board also noted that no defense nuclear low-level waste disposal facilities had approved the radiological performance assessments required by Department Order 5820.2A, Radioactive Waste Management. The recommendation called for a comprehensive, complex-wide review of low-level waste management, similar to that conducted by the Department on spent fuel. The Board also recommended development of a regularized program of low-level waste disposal needs, issuance of additional requirements and guidance regulating the management of lowlevel waste, conduct of studies aimed at improving the waste management program, and completion of radiological assessments which account for all contributing source terms of low-level waste disposal facilities.

At the start of calendar year 1998, all tasks in the following two task areas were completed; systems engineering and complex-wide review. During 1998, the Department continued to make good progress on completing the actions in the remaining four task areas; regulatory structure and process, radiological assessments, low-level waste projections and research and development.

Accomplishments by the Department during 1998 included:

- Completed 60 of 82 (over 73\%) total plan milestones through 1998.

- The draft DOE Order, Radioactive Waste Management, and the associated manual were made available for public review through a notice in the Federal Register on August 6,1998. DOE revised all of the documents based on comments received from the public, Board staff, DOE organizations, DOE contractors, and the panel of experts assembled to provide an independent review of the order revision products. At the end of December 1998, the Order and related documents were being prepared for distribution throughout DOE to obtain the concurrences necessary for issuance as DOE directives.

- On September 17, 1998, the Department submitted the Low-Level Waste Disposal Facilities Federal Review Group Manual to the BOARD. The current version of the manual provides guidance for review of performance assessments prepared in accordance with DOE Order 5820.2A, Radioactive Waste Management, and composite analyses prepared in accordance with the BOARD Recommendation 94-2 
Implementation Plan. The plan is to revise the manual after DOE O 435.1 is issued to reflect requirements of the revised order and also to incorporate feedback from previously conducted reviews.

- The Department issued the disposal authorization statement for the Los Alamos National Laboratory Low-Level Waste Disposal Area G authorizing the continued operations of the facility subject to the conditions in the disposal authorization statement. The Low-Level Waste Disposal Facilities Federal Review Group and the subordinate review teams continued their review activities of the other disposal facilities. The review teams for radiological assessments at the Oak Ridge Reservation and the Savannah River Site completed their reports. The Low-Level Waste Disposal Facilities Federal Review Group met to consider the reports and the related performance assessments/composite analyses, and made recommendations to management on the course of action to be taken for each disposal facility. In addition, the Nevada Test Site Area 3 review team completed the bulk of its review and initiated the preparation of its report.

- The Department also completed the last commitment in the Low-Level Waste Projections task area with the issuance of the Current and Planned Low-Level Waste Disposal Capacity Report, Revision 1. This report updates a report prepared two years ago. The current revision projects that the Department has adequate volumetric disposal capacity except for onsite disposal at the Los Alamos National Laboratory. Los Alamos is preparing an environmental impact statement that addresses increasing the disposal capacity at the site and has sufficient capacity for the near term. With the exception of the Savannah River Site Intermediate Level Vaults, the report projects adequate radiological capacity for the waste projected to be disposed at DOE disposal facilities. Although the report indicates a potential problem with radiological capacity for the Intermediate Level Vaults, there are mitigating conditions. First, the conservatism of the analysis and uncertainties associated with the extrapolation of radiological data likely overestimate the dose impact. Inventory controls, design modifications, and waste form changes may be used to ensure that the vaults do not cause an unacceptable dose impact. In addition, the Department appears to have excess capacity at other sites.

- The Department completed a document entitled Complex-Wide Strategy for Maintenance of Department of Energy Low-Level Waste Disposal Facility Performance Assessments and Composite Analyses. The document describes a strategy for integrating the Headquarters and Field Office activities related to performance assessment and composite analysis maintenance such that research and 
development needs for low-level waste disposal are addressed. The Department also prepared an implementation process for the strategy.

The Department's implementation plan for this recommendation requires several years to implement due to the magnitude and complexity of certain of the plan deliverables. The only remaining deliverables in the implementation plan are the completion and approval of the radiological assessments and composition analysis for the Department's disposal facilities and implementation of the low-level waste research and development needs. The Department expects to make significant progress in both of these areas in 1999 , and will complete all deliverables by the end of 2000 .

\section{Recommendation 94-1, Improved Schedule for Remediation in the Defense Nuclear Facilities Complex}

Recommendation 94-1 addresses the need within the Department to address the hazards and risks involving the storage of nuclear materials within the defense nuclear facilities complex. The recommendation calls for an accelerated schedule for stabilizing and repackaging high risk, unstable special nuclear materials, spent fuel, unstable solid plutonium residues, and highly radioactive liquids that pose potential safety concerns for the public, workers, and the environment. The Department continues to face increased requirements, competing needs, and additional challenges in remediation and storage of materials from disassembled nuclear weapons and materials, materials production processes, and reclamation of former production sites, equipment, and stored products and wastes. Resolving the safety issues encompassed by this recommendation continues to be of the utmost importance.

The Department made significant progress in 1998 toward completing plan deliverables. Significant accomplishments for 1998 include the following:

- Completed 105 of 164 original plan milestones (64\%). The revised plan contains 55 milestones.

- Completed an additional 17 percent of the spent fuel movements to improved storage conditions at the Idaho National Engineering and Environmental Laboratory for a total to date of 83 percent.

- Completed stabilization of high risk legacy vault items at Los Alamos National Laboratory. 
- Continued operation of the bagless transfer equipment for plutonium packaging at Savannah River. Using this equipment, 56 percent of all metal onsite has been packaged in a DOE-STD-3013-96 inner container.

- Completed removal of all uranium deposits with criticality potential from the nonoperational K-25 and K-29 uranium enrichment facilities at the East Tennessee Technology Park.

- Completed draining all high-level plutonium solution tanks at Rocky Flats Environmental Technology Site. Began tap-and-draining of process piping which will lead to removal of all remaining solutions.

- Began stabilization of higher-risk plutonium salts at Rocky Flats, with stabilization expected to be completed by mid-1999.

- Issued a Final Environmental Impact Statement and Record of Decision regarding alternatives for stabilization of certain residues and scrub alloy at Rocky Flats.

- Began shipments of Rocky Flats' sand, slag, and crucible residues to Savannah River Site for stabilization, as called for in the Residues Environmental Impact Statement.

- Completed stabilization of pre-existing inventories of sand, slag and crucible residues at Savannah River.

- Conducted research and development activities related to a number of new technologies developed to address problems regarding plutonium stabilization and remediation.

- Performed start-up and testing of a prototype system for plutonium stabilization and packaging at Rocky Flats. Similar standardized equipment is to be installed at several sites.

The Department's 94-1 implementation plan requires more than one year to complete due to the technical complexity and diversity of materials requiring stabilization at affected defense nuclear sites. Several of the implementation plan deliverables described in the original plan (issued February 1995) have been revised as described in a complete revision issued on December 28, 1998. The final stabilization actions are scheduled for completion by December 2005. 


\section{Recommendation 93-6, Maintaining Access to Nuclear Weapons Expertise in the Defense Nuclear Facilities Complex}

This recommendation expresses the Board's concern that the unique talents and experience of personnel have been and are being lost from the Department and its weapons complex as a result of changes in the Department's mission and emphasis, and its subsequent downsizing. The recommendation emphasized the need to retain access to, and capture the unique knowledge of, those individuals who have been engaged in weapons assembly, disassembly, and testing activities in order to avoid future safety problems in these areas. Retention of this information contributes to the Department's present and future capability to safely manage and maintain the weapons stockpile and disassemble existing weapons.

The Department completed the implementation plan deliverables by October 1996 and proposed closure of this recommendation in December 1996. The Department met with the Board in January 1997 to discuss completed actions and the path forward to closure. The Board indicated that it wanted to continue to monitor the actions which were started with this recommendation. Specific accomplishments in 1998 include:

- Completed archiving on weapons operations and testing, which included approximately 180 hours of videotaping, 3 technology panels, and 36 personnel interviews.

- Completed VENTEX 98 was a major Command Post Exercise to demonstrate the effectiveness of the Nuclear Test Organization (NTO) to respond to a prompt massive radiological venting as a result of an underground test (UGT) at the NTS. Many UGT key and critical positions were exercised for VENTEX 98 including the entire Test Controllers Scientific Panel. Five of the fourteen UGT Functional Areas (FAs) were utilized for this exercise. They were: Containment; Security; Timing and Control; Arming and Firing; and foremost the Test Control Center Activities.

- Performed STAGECOACH, a subcritical experiment (SCE) sponsored by the Los Alamos National Laboratory that was safely and successfully conducted in the Ula underground facility at the NTS. Both key and critical UGT identified Test Readiness positions comprising all of the NTO participated to varying degrees in this SCE. Twelve of the fourteen FAs for UGT were employed for this experiment at differing levels. They were: Containment; Security; Assembly; Storage and Transportation; Insertion and Emplacement; Timing and Control; Arming and Firing; Diagnostics; Test Control Center Activities (D-1 and D Day); Nuclear Design (minimal); Weapons Engineering (minimal); and Test Integration (minimal). Not 
exercised for the SCEs are Postshot Drilling (archived) and Nuclear Chemistry (archived).

- BAGPIPE, a SCE sponsored by Lawrence Livermore National Laboratory was also safely and successfully conducted at the Ula complex at the NTS this past year. Basically, the same UGT FAs utilized for STAGECOACH were also applied for BAGPIPE to varying degrees.

- Conducted 30 experiments safely at the Big Explosives Experimental Facility (BEEF) at the NTS utilizing the following UGT FAs: Assembly; Storage and Transportation; Insertion and Emplacement; Timing and Control; Arming and Firing; Diagnostics and some minimal Test Control Center Activities.

- Conducted over 20 experiments by the Defense Threat Reduction Agency at NTS which exercised some minor levels of UGT FAs. They were: Timing and Control; Arming and Firing and Diagnostics.

- Testing Information Project completed 3 outstanding Project Officer reports, conversion of digital waveform data to a single format on 10 events, validated data on 6 events and completed the process to transfer their UGT collection to the Technical Library and Corporate Archives.

- Weapon Seamless Safety archiving was completed on the following weapons: B53, W62, B61 Mod 3,4,10, 7 and 11, W80, W84 and W87. Work is progress and will be completed on schedule for the B83 and W88.

- Archiving for the Weapon Safety Specifications was completed on the following weapons: B53, W62, B61 Mod 3, 4, 10, 7, and 11, W84, and W87. Work is in progress on the W80 and B83 and will be completed in 1999.

The Department actions described in this plan are complete.

\section{Recommendation 93-5, Tank Waste Characterization Studies}

This recommendation noted that technical information on tank wastes was not sufficient to ensure that Hanford Site wastes could be safely stored, that associated operations could be conducted safely, and that future data requirements to support waste disposal could be met. The Board recommended that the Department upgrade and expedite the characterization efforts for the high-level waste tanks at the Hanford Site. This recommendation also called for revision of sampling protocols and expansion of the 
laboratory capacity. Lastly, this recommendation seeks integration of these characterization efforts with other systems engineering tasks.

The original implementation plan encompassed activities for developing a technical basis for characterization and for improving the sampling equipment. This was to be done in parallel with sampling and analyzing all 177 tanks for safety-related reasons by October 1996. The Department realized that tank safety issues could not be resolved solely by accelerating sampling and analysis. During 1996, this realization led to a major revision of the Department's implementation plan. The revision, completed in June 1996, focused on obtaining a better understanding of the safety-related phenomena, which can lead to safety concerns with the high-level waste tanks. Some of the principal accomplishments for 1998 on the revised implementation plan are as follows.

Sixteen additional tanks were sampled for characterization, bringing the total to 139 tanks which have been sampled. In addition, 10 tanks were resampled to support other operational commitments. Work continues on sampling and analyzing the remainder of the tanks.

125 Tank Characterization Reports were accepted by the Washington State Department of Ecology

Samples were obtained from high priority tanks to validate the tank farms authorization basis and support closure of the remaining safety issues. Unreviewed Safety Questions related to flammable gas and organic complexants were closed.

The first campaign to sluice high heat wastes out of tank C-106 was initiated in November 1998.

As previously reported, the implementation plan requires more than one year to implement due to the technical complexities of characterizing and analyzing the highlevel waste tanks. Because of these complexities, if sampling and analysis of all of the high-level tanks is required to resolve the safety issues raised by the Board, the revised implementation plan projects a completion date of 2002. However, on August 5, 1998, the Board held a public meeting to discuss the Department's path forward for closure of this Recommendation. During the public meeting, the Department outlined the actions necessary to allow it to propose closure of Recommendation 93-5 in 1999. The Department's strategy is based the assumption that analyses of samples obtained to date will demonstrate that characterization information collected so far is sufficient to show that current programmatic safety needs have been met and that a system is in place to respond to future needs. 
Recommendation 93-3, Improving Technical Capability in Defense Nuclear Programs

This recommendation raised concerns regarding the technical capability of the Department's personnel who are responsible for ensuring that safety is maintained at defense nuclear facilities. In the recommendation, the Board described its concerns regarding the Department's difficulty in attracting, developing, and retaining personnel who are adequately qualified by technical education and experience to provide the level and quality of management, direction, and guidance that are essential to the Department's safe operation of its defense nuclear facilities.

In April of 1997, the Department received a letter from the Board that requested an Implementation Plan revision to delete milestones that were no longer considered to be of value and establish an aggressive but achievable schedule for the new milestones. In response, the Secretary chartered a working group of senior line managers representing each field and program office having safety responsibilities at defense nuclear facilities to revise the Department's 93-3 Implementation Plan. The Secretary submitted the Revised Implementation Plan for Improving DOE Technical Capability in Defense Nuclear Facilities Programs to the Board on May 5, 1998, and the Board accepted the revised Plan on June 1, 1998.

Key accomplishments for 1998 are listed below:

- The Federal Technical Capability Panel (Panel) was established. The first meeting of the Panel was conducted in April 1998. A Charter was developed by the Panel members and approved by the Deputy Secretary in June 1998. The Panel met seven times in 1998 with three of those being face-to-face meetings. The Panel consists of senior line managers who have been designated as Agents to represent Headquarters and Field Offices with defense nuclear facilities safety responsibilities.

- Memoranda were signed by the appropriate Assistant Secretaries/Field Office Managers revising position descriptions and performance evaluation plans to reflect the Agents' duties and responsibilities.

- The Federal Technical Capability Policy was developed, reviewed and concurred with by the Panel in June 1998. The Policy was forwarded to the Directives organization in June 1998 for Departmental review and comment and then approved by the Secretary in December 1998. 
- The Manager's Guide to Administrative Flexibilities was revised based upon new initiatives and input from the field. The document was reviewed and approved by the Panel and forwarded to Directives in June 1998. The Guide was issued in December after approval of the Federal Technical Capability Policy.

- Workshops on administrative flexibilities for recruiting, hiring and retaining high quality technical staff were conducted in the field and at headquarters. These workshops were conducted by Panel agents and were based on the Guide "RECRUITING, HIRING, AND RETAINING HIGH QUALITY TECHNICAL STAFF; A Manager's Guide to Administrative Flexibilities".

- An overall review of the Functions, Responsibilities and Authorities Manual (FRAM) was conducted, and revisions were proposed for section 9.1.6, to reflect line management responsibilities for technical competence. The revision to the FRAM is being processed through the Directives system.

- In May 1998, an interim workforce analysis was completed by most of the organizations with defense nuclear facilities responsibility. This interim analysis identified critical technical skills which must be maintained to assure safe operations of defense nuclear facilities. It identified existing shortages and plans to deal with the shortages. The interim analysis was used as part of the strategy to reduce downsizing effects on technical capabilities and formed the basis for the more detailed staffing analysis completed in December 1998.

- Model policies and procedures to preserve critical technical skills associated with Facility Representative positions were developed and incorporated into a memorandum signed by the Deputy Assistant Secretary for Human Resources and the Associate Deputy Secretary for Field Management. The memorandum is titled Guidance on Retention of Facility Representative Technical Competence during Reductions in Force and is included, as Appendix D, in the guide entitled RECRUITING, HIRING, AND RETAINING HIGH QUALITY TECHNICAL STAFF; A Manager's Guide to Administrative Flexibilities.

- Based on the results of the interim staffing analysis, 201 Facility Representative positions were identified as critical technical capabilities. Implementation of the policies and procedures to preserve these Facility Representative capabilities was completed in October 1998. Implementation of policies and procedures to preserve other critical technical positions and capabilities identified in the staffing analysis is ongoing. 
- A working group was established to revised the program guidance for the Technical Leadership Development Program. A draft white paper and an issue paper were developed and sent to the Panel for review and discussed at its October 1998 meeting. This program guidance was approved by the Panel and submitted to the Deputy Secretary.

- The Technical Qualification Program Assessment Guidance and Criteria document was developed, reviewed by the Panel, and approved by the Chair of the Panel in July 1998. This guidance formed the basis for conducting and reporting the results of the Phase I Assessments and will be used for future assessments.

- Phase I Technical Qualification Program Assessments were conducted by teams of technical line personnel and training personnel and submitted to the Chair of the Panel. The Panel adopted a peer review process using a standardized checklist to complete the analyses of the assessment reports. Two Panel Agents independently reviewed and analyzed each of the reports. The two peer reviewers then discussed their results with the Agent representing the Office that was assessed. A summary report of the results of the assessments was approved by the Panel.

- Updated Technical Qualification Program Plans were developed by offices with defense nuclear facilities safety responsibilities and were provided to the Chair of the Federal Technical Capability Panel by December 1998. These plans were based on the results of the Phase I Assessments and will form the basis for revising the Technical Qualification Program in 1999.

- The Federal Technical Capability Program Assessment Guidance and Criteria document was developed, reviewed by the Panel, and approved by the Chair of the Panel in September 1998. The document forms the basis for conducting future evaluations of the Federal Technical Capability Panel using internal or independent experts.

- The Panel reviewed and revised the list of Senior Technical Safety Managers for the Department.

As previously reported, completion of this implementation plan requires more than one year. The actions itemized in the revised implementation plan will apply across all defense nuclear facilities of the Department and involve significant programmatic and cultural changes. All actions are projected to be complete by March 2000. 


\section{Recommendation 93-1, Standards Utilization in Defense Nuclear Facilities}

Recommendation 93-1 focuses on ensuring that the level of safety assurance at those facilities that assemble, disassemble, and test nuclear weapons is at least as rigorous as that required at other defense nuclear facilities. The Department's implementation plan calls for identification and modifications of the Department's orders and directives to strengthen the safety assurance for nuclear weapons operations and facilities. The implementation plan also incorporated the recommendations contained in the Nuclear Explosive Safety Study Corrective Action Plan which implemented actions associated with the Board's Nuclear Explosive Safety Study Independent Review.

In April 1996, the Department approved and issued new departmental orders, an implementation guide, and a technical standard that integrated nuclear explosive safety with nuclear facility safety. These directives were issued for simultaneous implementation and formal coordination to expedite incorporation of the improved safety requirements into nuclear explosive operations. Following departmental review and coordination, these documents were revised to incorporate current nuclear explosive safety methods (e.g. hazard analysis, connections with the facility safety analysis report). The following directives were issued in final form for implementation on January 17, 1997:

- Order 452.1A, "Nuclear Explosive and Weapon Surety Program"

- Order 452.2A, "Safety of Nuclear Explosive Operations"

- Guide 452.2-1A, "Implementation Guide for use with Department Order 452.2A, Safety of Nuclear Explosive Operations"

- Standard DOE-DP-STD-3015-97, "Nuclear Explosive Safety Study Process"

- Standard DOE-STD-ZZZZ-95, "Personnel Assurance Program (PAP)"

The approved directives established a one-year period for implementation in current operations and contractual documents. The Department incorporated the 452 Series Orders, dated January 17, 1997, in the University of California contract in September 1997, the Pantex Mason \& Hanger contract in May 1998, and the Bechtel and WSI contracts in August 1998. This action mandated and enforced integrated safety efforts already underway in the field. There were exceptions which relate primarily to completion of the hazard analysis reports which are being developed in conjunction with the integrated safety process. 
A technical standard DOE-DP-STD-XXXX-96, "Preparation Guide for the U.S. Department of Energy Hazard Analysis Reports for Nuclear Explosive Operations" should be published in early 1999. This standard covers weapon-specific hazards and controls referenced in the new 452 Series Orders. It has been used on a pilot program basis and refined based on the lessons learned. Specifically, it was used as a pilot program for the W69 warhead dismantlement. This pilot effort involving the national laboratories and the user community has provided useful information to restructure the standard into a more effective document.

The review and comment process for standard DOE-STD-ZZZZ-95 resulted in the development and approval of an Interim Rule on the operations and administration of the PAP covering nuclear explosive workers. The Interim PAP rule was approved on October 2, 1996, with completion of the final rule, 10 CFR Part 711, Personnel Assurance Program, Final Rule, on September 8, 1998.

As previously reported, this Implementation Plan has required more than one year to implement due to the multi-site nature of the planned actions. The Department anticipates completion of the Hazard Analysis Report Standard and expects to propose closure to the Board in early 1999.

\section{Report on Implementation Plans Requiring More Than One Year}

When the Congress established the Board, they envisioned that the Department would typically be able to resolve Board recommendations within a relatively short period of time, such as within one year after the Department submits its implementation plan. To monitor the Department's performance in completing implementation plans, the Congress included a provision in the Board's enabling legislation which requires notification from the Department to Congress whenever the Department takes more than one year to complete an implementation plan in response to a Board recommendation. The enabling legislation also requires the reasons for requiring more than one year and the expected completion date.

The Department has required more than one year to complete a number of implementation plans for Board recommendations. This has occurred for a variety of reasons including the size and scope of issues being addressed and challenges in accomplishing complex-wide changes. The Department routinely makes the required Congressional notification in conjunction with the Department's Annual Report to Congress on Board activities (i.e., this report), which is also required by the Board's enabling legislation. In accordance with 42 U.S.C. $\$ 2286 \mathrm{~d}(\mathrm{f})(1)$, the following active implementation plans are expected to require a total of more than one year to complete. 
93-1, Standards Utilization in Defense Nuclear Facilities*

93-3, Improving Technical Capability in Defense Nuclear Programs*

93-5, Hanford Waste Tanks Characterization Studies*

94-1, Improved Schedule for Remediation*

94-2, Safety Standards for Low Level Waste*

94-4, Deficiencies in Criticality Safety at Oak Ridge, Y-12*

95-2, Safety Management*

96-1, In-Tank Precipitation System*

97-1, Safe Storage of Uranium-233*

97-2, Criticality Safety*

* - Previously reported to require more than one year to implement.

The associated reasons and expected completion schedules for each implementation plan were provided with the previous discussion of Department activities for each Board recommendation. 


\section{E. Categorization of Board Recommendations}

There are a number of ways to group and categorize Board recommendations. These groupings provide insights into the types of safety issues the Department is addressing and the schedules for issue resolution. Three different methods of categorizing recommendations are discussed below.

\section{Scope of Organizations Involved}

Recommendations vary in the scope of organizations involved. Three categories can be defined: 1) Department-wide, 2) multiple-sites/multiple-organizations, and 3) singlesite/single-organization. In general, the more organizations that are involved, the more complex and time-consuming is the resolution. Department-wide recommendations are most likely to involve complex management and coordination efforts, and complex are also more likely to involve culture changes which require more time and attention to assimilate. Single-site recommendations are often of a more technical nature, while complex-wide recommendations often involve management issues. The following table shows the scope of organizations involved for open Board recommendations and also those closed over the past four years.

\section{DEPARTMENT-WIDE RECOMMENDATIONS}

\begin{tabular}{||l|l||}
\hline \multicolumn{1}{|c|}{ Open Recommendations } & \multicolumn{1}{|c|}{ Closed Recommendations (1995-1998) } \\
\hline $\begin{array}{l}\text { 98-1, Resolution of DOE Internal Oversight } \\
\text { Findings }\end{array}$ & $92-6$, Operational Readiness Reviews \\
\hline 95-2, Safety Management & $92-5$, Discipline of Operations \\
\hline 94-5, Rules, Orders, and Other Requirements & $92-2$, Facility Representatives \\
\hline 94-2, Safety Standards for Low Level Waste & $91-6$, Radiation Protection \\
\hline 94-1, Improved Schedule for Remediation & $90-2$, Codes and Standards \\
\hline 93-3, Improved Technical Capability & \\
\hline
\end{tabular}


1998 Annual Report to Congress

MULTIPLE-SITE/MULTIPLE-ORGANIZATION RECOMMENDATIONS

\begin{tabular}{||c|c||}
\hline \multicolumn{1}{|c|}{ Open Recommendations } & Closed Recommendations (1995-1998) \\
\hline $\begin{array}{l}\text { 97-2, Criticality Safety } \\
\text { 93-4, Environmental Restoration Management } \\
\text { Contracts }\end{array}$ \\
\hline 97-1, Safe Storage of Uranium-233 & $93-2$, Critical Experiments Capability \\
\hline $\begin{array}{l}\text { 93-6, Nuclear Weapons Expertise } \\
\text { 93-1, Standards Utilization at Defense Nuclear } \\
\text { Programs }\end{array}$ & \\
\hline
\end{tabular}

\section{SINGLE-SITE/SINGLE-ORGANIZATION RECOMMENDATIONS}

\begin{tabular}{|c|c|}
\hline Open Recommendations & Closed Recommendations (1995-1998) \\
\hline 98-2, Safety Management at the Pantex Plant & $\begin{array}{l}\text { 92-4, Multi-Function Waste Tank Facility at } \\
\text { Hanford (proposed) }\end{array}$ \\
\hline $\begin{array}{l}\text { 96-1, In-Tank Precipitation Facility (Savannah } \\
\text { River) }\end{array}$ & 90-7, Hanford Waste Tanks Ferrocyanide Safety \\
\hline $\begin{array}{l}\text { 95-1, Improved Safety of Cylinders Containing } \\
\text { Depleted Uranium (Oak Ridge) }\end{array}$ & $\begin{array}{l}\text { 90-6, Rocky Flats Plutonium in the Ventilation } \\
\text { Ducts }\end{array}$ \\
\hline $\begin{array}{l}\text { 94-4, Deficiencies in Criticality Safety at Oak } \\
\text { Ridge Y-12 }\end{array}$ & 90-5, Systematic Evaluation Plans (Rocky Flats) \\
\hline 94-3, Rocky Flats Seismic and Systems Safety & $\begin{array}{l}\text { 90-4, Rocky Flats Operational Readiness } \\
\text { Reviews }\end{array}$ \\
\hline 93-5, Hanford Waste Tanks Characterization & \\
\hline
\end{tabular}

\section{Lead Implementing Organization}

Most Department implementation plans are managed from Department headquarters organizations. Three recommendations, which each involve a single site, are managed from the associated field or operations office. The subjects of the three recommendations managed at the site level are all related to environmental management and clean-up. 
LEAD ORGANIZATION: ENVIRONMENTAL MANAGEMENT

\begin{tabular}{||l||}
\hline Open Recommendations \\
\hline $97-1$, Safe Storage of Uranium-233 \\
\hline $94-2$, Safety Standards for Low Level Waste \\
\hline $94-1$, Improved Schedule for Remediation \\
\hline
\end{tabular}

\section{LEAD ORGANIZATION: DEFENSE PROGRAMS}

\begin{tabular}{||l||}
\hline Open Recommendations \\
\hline $98-2$, Safety Management at the Pantex Plant \\
\hline $97-2$, Criticality Safety \\
\hline 94-4, Deficiencies in Criticality Safety at Oak Ridge Y-12 \\
\hline $93-6$, Nuclear Weapons Expertise \\
\hline $93-1$, Standards Utilization at Defense Nuclear Programs \\
\hline
\end{tabular}

\section{LEAD ORGANIZATION: OTHER HEADQUARTERS ORGANIZATIONS}

\begin{tabular}{||ll||}
\hline \hline Open Recommendations \\
\hline $98-1, \quad$ Resolution of Internal Oversight Findings (Office of the Secretary) \\
\hline $95-2, \quad$ Safety Management (Office of the Secretary) \\
\hline $95-1, \quad \begin{array}{l}\text { Improved Safety of Cylinders Containing Depleted Uranium (Nuclear Energy, Science } \\
\text { and Technology) }\end{array}$ \\
\hline $94-5, \quad$ Rules, Orders, and Other Requirements (Environment, Safety, and Health) \\
\hline $93-3, \quad$ Improved Technical Capability (Management and Administration) \\
\hline
\end{tabular}

\section{LEAD ORGANIZATION: FIELD AND OPERATIONS OFFICES}

\begin{tabular}{|l||}
\hline Open Recommendations \\
\hline 96-1, In-Tank Precipitation Facility (Savannah River Operations Office) \\
\hline 94-3, Rocky Flats Seismic and Systems Safety (Rocky Flats Field Office) \\
\hline 93-5, Hanford Waste Tank Characterization (Richland Operations Office) \\
\hline
\end{tabular}

\section{Progress Toward Completion of Implementation Plans}

Implementation plans with long-term completion dates involve more uncertainty than those with shorter completion schedules. The projected deliverables and schedules are 
less certain the further out are the projected plan due dates. The long-term plans often involve research, development and application of new techniques. Due to the nature of these activities, the schedules are less certain and the basic direction of the plan may even need to be substantially changed based on the outcome of intermediate activities. For plans to be effective and useful, it must be understood that plan deliverables and milestones can not be known with certainty several years in advance and should not be held rigid in light of new information and new priorities. Flexibility is required in adjusting plan deliverables and milestones as the plan is being executed, particularly for plans that extend more than the one year that the Congress envisioned for typical implementation plan completion.

\section{IMPLEMENTATION PLANS COMPLETE}

\begin{tabular}{|l||}
\hline Open Recommendations \\
\hline 95-1, Improved Safety of Cylinders Containing Depleted Uranium \\
\hline 94-5, Rules, Orders, and Other Requirements \\
\hline 94-3, Rocky Flats Seismic and Systems Safety \\
\hline 93-6, Nuclear Weapons Expertise \\
\hline
\end{tabular}

IMPLEMENTATION PLANS PROJECTED TO BE COMPLETE IN 1999

\begin{tabular}{||l||}
\hline Open Recommendations (Projected Completion) \\
\hline 97-2, Criticality Safety (1999) \\
\hline 97-1, Safe Storage of Uranium-233 (1999) \\
\hline 96-1, In-Tank Precipitation Facility at Savannah River (Pending outcome of alternatives review) \\
\hline 95-2, Safety Management (1999) \\
\hline 94-4, Deficiencies in Criticality Safety at Oak Ridge Y-12 (1999) \\
\hline 93-5, Hanford Waste Tank Characterization (June 1999) \\
\hline 93-1, Standards Utilization at Defense Nuclear Programs (1999) \\
\hline
\end{tabular}

IMPLEMENTATION PLANS PROJECTED TO BE COMPLETE AFTER 1999

\begin{tabular}{|l||}
\hline Open Recommendations (Projected Completion) \\
\hline 94-2, Safety Standards for Low Level Waste (2000) \\
\hline 94-1, Improved Schedule for Remediation (2005) \\
\hline 93-3, Improved Technical Capability (2000) \\
\hline
\end{tabular}




\section{OTHER BOARD INTERFACE ACTIVITIES}

The Department shares with the Board the common goal of ensuring adequate protection at its defense nuclear facilities of the health and safety of the public. To accomplish this goal, the Department's policy has been to:

- Fully cooperate with the Board;

- Provide access to information necessary for the Board to accomplish its responsibilities;

- Thoroughly consider the recommendations and other safety information provided by the Board;

- Consistently meet commitments to the Board; and

- Conduct interactions with the Board in accordance with the highest professional standards.

The Office of the Departmental Representative to the Defense Nuclear Facilities Safety Board manages the Department's overall interface with the Board and provides advice and direction for resolving identified safety issues.

The Board and its staff have made a positive impact on Department safety across a wide variety of issues during 1998, particularly the development and accelerated implementation of integrated safety management, and continued improvement in safety directives. The dialogue between the individual Board members and senior Department officials has been frank and open regarding improvements that were needed. As a result of interaction with the Board and its staff, the Department now has a more complete and effective set of safety requirements and expectations, and a more thorough understanding of how each of the previous safety requirements were addressed during the transition. The Board has also been instrumental in the development of Department guidance for incorporating new safety requirements into contracts and accomplishing contractor implementation.

\section{Coordination of Board review of Department safety directives}

One of the Board's significant responsibilities is the review and evaluation of the Department's safety directives and standards that apply to the design, construction, operation, and decommissioning of Departmental defense nuclear facilities. In keeping 


\section{Annual Report to Congress}

with this function, the Board has reviewed the body of the Department's directives (including rules, policies, notices, orders, manuals, handbooks, guides, and standards) and identified those specific directives "of interest" to the Board. Whenever the Department develops changes to these identified directives or identifies new directives potentially "of interest" to the Board, the Board is provided an opportunity to review and comment on the changes prior to approval by Department management. The Office of the Departmental Representative coordinates this review process with the Board to ensure that the Board and its staff are notified of each change and given an opportunity for review and comment prior to issuance. Appendix A provides both: 1) a listing of the orders identified as "of interest" to the Board, and 2) a listing of Departmental safety directives "of interest" to the Board that were changed in 1998.

\section{Briefings, Site Visits, and other Board Interactions}

The Department has continued to interact extensively and effectively with the Board and its staff. Department personnel supported over 240 site briefings and site visits by the Board or its staff in 1998. This has included provision of logistical and technical support and interface, as appropriate, to facilitate unrestricted access by the Board and its staff to the Department's facilities. Appendix B provides a summary of site visits supported by the Department during 1998. In addition, Department personnel conducted numerous teleconferences and video conferences to exchange information and resolve safety issues.

In 1998, the Department and the Board exchanged over 180 items of correspondence (not including transmittal of requested information and routine distribution of assessments and evaluations). A large portion of the written communications between the Board and the Department involves the Board's recommendations and the associated deliverables, schedules, and reporting requirements contained in the Department's implementation plans. In addition, the Department receives and responds to trip reports detailing visits by the Board or its staff to the Department's facilities, as well as specific requests from the Board or its staff for particular information or action by the Department. Appendix $C$ provides a summary of key correspondence between the Department and the Board for 1998.

\section{Responses to Board Reporting Requirements}

The Board communicates with the Department through a variety of mechanisms including formal recommendations, formal reporting requirements, letters requesting action and information, letters providing suggestions, letters providing information such as staff issue reports and trip reports, Board and Board staff requests for information, 
public meetings, briefings and discussions, and site visits. The Board's choice of communication vehicle tends to indicate the level of the Board's concern, with the more formal vehicles used for clearly-defined safety issues that require prompt attention by Departmental managers. During 1998, the Board issued seven sets of formal reporting requirements, pursuant to 42 U.S.C. $2286 \mathrm{~b}(\mathrm{~d})$ :

\begin{tabular}{|c|l|c|}
\hline Date & \multicolumn{1}{|c|}{ Topic of Reporting Requirements } & $\begin{array}{c}\text { Days for } \\
\text { Report }\end{array}$ \\
\hline $3 / 20 / 98$ & $\begin{array}{l}\text { Feedback and improvement function of integrated safety } \\
\text { management }\end{array}$ & 60 \\
\hline $3 / 26 / 98$ & $\begin{array}{l}\text { Safety concerns regarding high-efficiency particulate air } \\
\text { (HEPA) filters }\end{array}$ & 30 \\
\hline $6 / 12 / 98$ & Control of maintenance activities at Oak Ridge Y-12 Plant & 60 \\
\hline $7 / 10 / 98$ & $\begin{array}{l}\text { Americium/Curium solution stabilization at Savannah River } \\
\text { Site }\end{array}$ & 45 \\
\hline $7 / 13 / 98$ & $\begin{array}{l}\text { Plutonium Stabilization at Hanford's Plutonium Finishing } \\
\text { Plant }\end{array}$ & 60 \\
\hline $11 / 17 / 98$ & $\begin{array}{l}\text { Startup Preparations for certain classified activities at the Los } \\
\text { Alamos National Laboratory }\end{array}$ & 30 \\
\hline $12 / 14 / 98$ & $\begin{array}{l}\text { Resolution of Board comments on Departmental standard for } \\
\text { packaging and storing Uranium-233-bearing materials }\end{array}$ & 32 \\
\hline
\end{tabular}

The Board's reporting requirements and the Department's responses are available on the Departmental Representative's web site at http://dr.tis.doe.gov.

\section{Board Public Meetings}

The Board holds public meetings periodically to review significant safety and management issues in a public forum. The Board provides advance public notice for these meetings pursuant to the provision of the "Government in the Sunshine Act" (5 U.S.C. $\S 552 \mathrm{~b}$ ). During 1998, the Department supported the following seven public meetings conducted by the Board: 


\begin{tabular}{|c|l|c|}
\hline Date & \multicolumn{1}{|c|}{ Topic of Public Meeting } & Location \\
\hline $3 / 24 / 98$ & $\begin{array}{l}\text { Status of activities associated with the Department's } \\
\text { implementation plan for integrated safety management } \\
\text { (related to Board recommendation 95-2) }\end{array}$ & $\begin{array}{c}\text { Washington, } \\
\text { D.C. }\end{array}$ \\
\hline $5 / 7 / 98$ & $\begin{array}{l}\text { Status of activities associated with the Department's } \\
\text { implementation plan for remediating hazardous nuclear } \\
\text { materials (related to Board recommendation 94-1) }\end{array}$ & $\begin{array}{l}\text { Washington, } \\
\text { D.C. }\end{array}$ \\
\hline $6 / 2 / 98$ & $\begin{array}{l}\text { Status of activities associated with the Department's } \\
\text { implementation plan for remediating hazardous nuclear } \\
\text { materials (related to Board recommendation 94-1) }\end{array}$ & $\begin{array}{c}\text { Washington, } \\
\text { D.C. }\end{array}$ \\
\hline $6 / 24 / 98$ & $\begin{array}{l}\text { Status of activities associated with the Department's } \\
\text { implementation plan for integrated safety management, } \\
\text { including feedback and improvement processes (related to } \\
\text { Board recommendation 95-2) }\end{array}$ & $\begin{array}{l}\text { Washington, } \\
\text { D.C. }\end{array}$ \\
\hline $8 / 4 / 98$ & $\begin{array}{l}\text { Status of activities associated with the Department's } \\
\text { implementation plan for systems engineering at the Hanford } \\
\text { Tank Waste Remediation System (related to Board } \\
\text { recommendation 92-4) }\end{array}$ & $\begin{array}{c}\text { Richland, } \\
\text { Washington }\end{array}$ \\
\hline $8 / 5 / 98$ & $\begin{array}{l}\text { Status of activities associated with the Department's } \\
\text { implementation plan for accelerated characterization of } \\
\text { Hanford tank wastes (related to Board recommendation 93-5) }\end{array}$ & $\begin{array}{l}\text { Richland, } \\
\text { Washington }\end{array}$ \\
\hline $9 / 22 / 98$ & $\begin{array}{l}\text { Status of activities associated with the Department's } \\
\text { implementation plan for integrated safety management, } \\
\text { including feedback and improvement processes (related to } \\
\text { Board recommendation 95-2) }\end{array}$ & Washington, \\
D.C. \\
\hline
\end{tabular}

\section{Secretary of Energy Quarterly Briefings with the Board Members}

The Secretary initiated scheduled quarterly briefings between the Board members and senior Department management in 1994. These sessions continued during 1998. The Department typically is represented in these quarterly sessions by the Secretary, Deputy Secretary, Under Secretary, and the Departmental Representative. This forum facilitates 
senior level information exchange on key safety and management issues, and on relative priorities and directions.

\section{Safety Issues Management System}

The Department established a Department-wide commitment management tool, the Safety Issues Management System, in August 1995. Through use of this tool, the Department has reduced the number of outstanding commitments related to Board recommendations from 694 in August 1995 to 184 in December 1998. The total number of overdue commitments related to Board recommendations has also declined significantly, from 245 in August 1995 to 71 in December 1998. In addition to commitments and actions related to Board recommendations, the Safety Issues Management System also manages commitments and actions related to other interactions between the Department and the Board, such as Board requests for action or information and Department commitments in letters to the Board. Since these "letter commitments" were first tracked in mid 1996, 228 letter commitments have been identified of which 189 have been completed.

The Office of the Departmental Representative conducts qualitative and technical reviews of the Department's implementation plans and other outgoing correspondence to the Board to identify and capture Department commitments. Commitment information identified from these documents is entered into the Safety Issues Management System database. Distribution of monthly summary reports on the status of commitment implementation or completion includes responsible Department managers, points of contact, and Secretarial Officers. These personnel can access detailed information, and use various view, sort, and report formats, via an on-line, internet-based user interface.

\section{Information Archive of Board-Related Documents}

The Departmental Representative maintains an information archive of all Department/Board correspondence, reports, plans, assessments, and transmittals. In 1996, the Departmental Representative began transferring the archived information onto a dedicated Internet web site, thus increasing accessibility within the Department complex and by the general public. During 1997 and 1998, the web site was substantially expanded and made more user-friendly. The objectives of the web site upgrade effort were to improve communications and coordination among Department interface personnel, to save time and money by eliminating paper distribution where practical, and to provide an effective web-based tool for interface personnel to research safety and management issues. At present, over 1,250 individual documents are provided on the web site. New documents are added promptly upon receipt. The 
Internet web site address (http://dr.tis.doe.gov) was also adjusted so that it is easier to remember and communicate. Additional web site improvements are planned for 1999.

The following types of documents are included in the information archive:

- Board recommendations,

- Department responses and implementation plans,

- Department letters to the Board,

- Board letters to the Department,

- Selected key letters concerning the status of recommendations,

- Policy statements from the Secretary and the Board,

- Annual Reports to Congress from the Secretary and the Board concerning Board-related matters,

- Operations/Area Office questions and answers about the Board,

- Resumes of the Board members,

- Department Manual for Interface with the Board, and

- Board staff issue reports provided to the Department by the Board. 


\section{Appendix A \\ Orders and Departmental Safety Directives of Interest to the Board}

This Appendix provides both: 1) a listing of the orders identified as "of interest" to the Board, and 2) a listing of Departmental safety directives "of interest" to the Board that were changed in 1998.

\section{Orders of Interest to the Board}

\begin{tabular}{|c|c|c|}
\hline Order & Title & Note \\
\hline O151.1 & Comprehensive Emergency Management System & 3 \\
\hline O210.1 & Performance Indicators and Analysis of Operations Information & 3 \\
\hline O225.1A & Accident Investigations & 3 \\
\hline 0231.1 & Environment, Safety, and Health Reporting & 3 \\
\hline $\mathrm{O} 232.1 \mathrm{~A}$ & Occurrence Reporting and Processing of Operational Information & 3 \\
\hline $0251.1 \mathrm{~A}$ & Directives System & 3 \\
\hline O2.52.1 & Technical Standards Program & 3 \\
\hline 0360.1 & Training & 3 \\
\hline O420.1 & Facility Safety & 3 \\
\hline O425.1A & Startup and Restart of Nuclear Facilities & 3 \\
\hline O430.1 & Life Cycle Asset Management & 3 \\
\hline O435.1 & Radioactive Waste Management (currently in draft) & 4 \\
\hline O440.1A & Worker Protection Management for DOE Federal and Contractor Employees & 3 \\
\hline P441.1 & Radiological Protection for DOE Activities & 4 \\
\hline O451.1A & National Environmental Policy Act Compliance Program & 3 \\
\hline O452.1A & Nuclear Explosive and Weapon Surety Program & 3 \\
\hline O452.2A & Safety of Nuclear Explosive Operations & 3 \\
\hline O460.1A & Packaging and Transportation Safety & 3 \\
\hline 0460.2 & Departmental Materials Transportation and Packaging Management & 3 \\
\hline $01300.2 \mathrm{~A}$ & Department of Energy Technical Standards Program & 1 \\
\hline O1360.2B & Unclassified Computer Security Program & 1 \\
\hline O1540.2 & Hazardous Material Packaging for Transport - Administrative Procedures & 1 \\
\hline
\end{tabular}


1998 Annual Report to Congress

\begin{tabular}{|c|c|c|}
\hline Order & Title & Note \\
\hline $01540.3 \mathrm{~A}$ & $\begin{array}{l}\text { Base Technology for Radioactive Material Transportation Packaging } \\
\text { Systems }\end{array}$ & 1 \\
\hline O3790.1B & Federal Employee Occupational Safety and Health Program & 4 \\
\hline O4330.4B & Maintenance Management Program & 1 \\
\hline 04700.1 & Project Management System & 1 \\
\hline O5000.3B & Occurrence Reporting and Processing of Operations Information & 1 \\
\hline O5400.1 & General Environmental Protection Program & 1 \\
\hline $05400.2 \mathrm{~A}$ & Environmental Compliance Issue Coordination & 1 \\
\hline 05400.3 & Hazardous and Radioactive Mixed Waste Program & 4 \\
\hline 05400.4 & $\begin{array}{l}\text { Comprehensive Environmental Response, Compensation, and Liability Act } \\
\text { Requirements }\end{array}$ & 1 \\
\hline 05400.5 & Radiation Protection of the Public and the Environment & 1 \\
\hline O5440.1E & National Environmental Policy Act Compliance Program & 1 \\
\hline O5480.1B & Environment, Safety and Health Program for DOE Facilities & 1 \\
\hline O5480.3 & $\begin{array}{l}\text { Safety Requirements for the Packaging and Transportation of Hazardous } \\
\text { Materials, Hazardous Substances, and Hazardous Wastes }\end{array}$ & 1 \\
\hline O5480.4 & Environment Protection, Safety, and Health Protection Standards & 1 \\
\hline O5480.5 & Safety of Nuclear Facilities & 1 \\
\hline O5480.6 & Safety of Department of Energy-Owned Nuclear Reactors & 1 \\
\hline O5480.7A & Fire Protection & 1 \\
\hline O5480.8A & Contractor Occupational Medical Program & 1 \\
\hline O5480.9A & Construction Safety and Health Program & 1 \\
\hline O5480.10 & Contractor Industrial Hygiene Program & 1 \\
\hline O5480.11 & Radiation Protection for Occupational Workers & 1 \\
\hline O5480.15 & $\begin{array}{l}\text { Department of Energy Laboratory Accreditation Program for Personnel } \\
\text { Dosimetry }\end{array}$ & 1 \\
\hline O5480.17 & Site Safety Representatives & 1 \\
\hline O5480.18B & Nuclear Facility Training Accreditation Program & 1 \\
\hline O5480.19 & Conduct of Operations Requirements for DOE Facilities & 1 \\
\hline
\end{tabular}


1998 Annual Report to Congress

\begin{tabular}{|c|c|c|}
\hline Order & Title & Note \\
\hline O5480.20A & $\begin{array}{l}\text { Personnel Selection, Qualification, Training and Staffing Requirements at } \\
\text { DOE Reactor and Non-Reactor Nuclear Facilities }\end{array}$ & 1 \\
\hline 05480.21 & Unreviewed Safety Questions & 1 \\
\hline 05480.22 & Technical Safety Requirements & 1 \\
\hline O5480.23 & Nuclear Safety Analysis Reports & 1 \\
\hline O5480.24 & Nuclear Criticality Safety & 1 \\
\hline 05480.25 & Safety of Accelerator Facilities & 1 \\
\hline 05480.26 & $\begin{array}{l}\text { Trending and Analysis of Operations Information Using Performance } \\
\text { Indicators }\end{array}$ & 1 \\
\hline 05480.28 & Natural Phenomena Hazards Mitigation & 1 \\
\hline O5480.29 & Employee Concerns Management System & 1 \\
\hline O5480.30 & Nuclear Reactor Safety Design Criteria & 1 \\
\hline O5480.31 & Startup and Restart of Nuclear Facilities & 1 \\
\hline O5481.1B & Safety Analysis and Review System & 1 \\
\hline O5482.1B & Environment, Safety, and Health Appraisal Program & 1 \\
\hline O5483.1A & $\begin{array}{l}\text { Occupational Safety and Health Program for DOE Contractor Employees at } \\
\text { Government-Owned Contractor-Operated Facilities }\end{array}$ & 1 \\
\hline O5484.1B & $\begin{array}{l}\text { Environmental Protection, Safety and Health Protection Information } \\
\text { Reporting Requirements }\end{array}$ & 1 \\
\hline O5500.1B & Emergency Management System & 1 \\
\hline O5500.2B & $\begin{array}{l}\text { Emergency Categories, Classes, and Notification and Reporting } \\
\text { Requirements }\end{array}$ & 1 \\
\hline O5500.3A & Planning and Preparedness for Operational Emergencies & 1 \\
\hline $05500.4 \mathrm{~A}$ & Public Affairs Policy and Planning Requirements for Emergencies & 1 \\
\hline O5500.7B & Emergency Operating Records Protection Program & 1 \\
\hline 05500.10 & Emergency Readiness Assurance Program & 1 \\
\hline O5530.1A & Accident Response Group & 2 \\
\hline 05530.2 & Nuclear Emergency Search Team & 2 \\
\hline 05530.3 & Radiological Assistance Program & 2 \\
\hline
\end{tabular}




\section{Annual Report to Congress}

\begin{tabular}{|c|c|c|}
\hline Order & Title & Note \\
\hline O5530.4 & Aerial Measuring System & 2 \\
\hline O5600.1 & $\begin{array}{l}\text { Management of the Department of Energy Weapon Program and Weapon } \\
\text { Complex }\end{array}$ & 2 \\
\hline O5610.10 & Nuclear Explosive and Weapon Safety Program & 2 \\
\hline O5610.11 & Nuclear Explosive Safety & 2 \\
\hline 05610.12 & $\begin{array}{l}\text { Packaging and Offsite Transportation of Nuclear Components, and Special } \\
\text { Assemblies Associated with the Nuclear Explosive and Weapon Safety } \\
\text { Program }\end{array}$ & 2 \\
\hline O5632.1C & Protection and Control of Safeguards and Security Interests & 1 \\
\hline O5632.11 & Physical Protection of Unclassified Irradiated Reactor Fuel in Transit & 4 \\
\hline O5700.6C & Quality Assurance & 1 \\
\hline O5820.2A & Radioactive Waste Management & 1 \\
\hline O6430.1A & General Design Criteria & 1 \\
\hline 10CFR820 & Procedural Rules for DOE Nuclear Activities & 3 \\
\hline $\begin{array}{l}\text { 10CFR } \\
830.110\end{array}$ & Safety Analysis Reports & 3 \\
\hline $\begin{array}{l}\text { 10CFR830. } \\
112\end{array}$ & Unreviewed Safety Requirements & 3 \\
\hline $\begin{array}{l}10 \text { CFR } \\
830.120\end{array}$ & Quality Assurance Requirements & 3 \\
\hline $\begin{array}{l}10 \text { CFR } \\
830.310\end{array}$ & Conduct of Operations & 3 \\
\hline $\begin{array}{l}10 \mathrm{CFR} \\
830.320\end{array}$ & Technical Safety Requirements & 3 \\
\hline $\begin{array}{l}10 \text { CFR } \\
830.330\end{array}$ & Training and Qualification & 3 \\
\hline $\begin{array}{l}10 \mathrm{CFR} \\
830.340\end{array}$ & Maintenance Management & 3 \\
\hline 10 CFR 834 & Radiation Protection of the Public and the Environment & 3 \\
\hline 10 CFR 835 & Occupational Radiation Protection & 3 \\
\hline
\end{tabular}


Notes:

(1) On Board's original list of 51 Orders of Interest; some of these have been canceled but remain in effect in certain contracts.

(2) Added to Board's list of Orders of Interest with expansion of Board's jurisdiction to include weapons assembly, disassembly, and testing safety.

(3) Added to Board's list due to conversion to three-digit orders and nuclear safety rules.

(4) Other additions based on ongoing Board staff review and evaluation. 
DOE Safety Directives Coordinated with the Board Staff And Issued in 1998

\begin{tabular}{|c|c|c|c|c|}
\hline Directive & Title & Date & $\begin{array}{l}\text { New/ } \\
\text { Revised }\end{array}$ & Comment \\
\hline $\begin{array}{l}10 \mathrm{CFR} \\
835\end{array}$ & Occupational Radiation Protection & $10 / 2 / 98$ & new & \\
\hline P 420.1 & $\begin{array}{l}\text { Federal Technical Capability Policy } \\
\text { For DNFSB }\end{array}$ & $12 / 10 / 98$ & new & \\
\hline P 450.6 & $\begin{array}{l}\text { Secretary Policy on Environment, } \\
\text { Safety, and Health }\end{array}$ & $4 / 14 / 98$ & new & \\
\hline $\mathrm{O} 251.1 \mathrm{~A}$ & Directives System & $1 / 30 / 98$ & revised & Replaced O 251.1 \\
\hline O 414.1 & Quality Assurance & $11 / 24 / 98$ & new & Replaced O 5700.6C \\
\hline 0420.2 & Safety of Accelerator Facilities & $11 / 5 / 98$ & new & Replaced O 5480.25 \\
\hline $\mathrm{O} 425.1 \mathrm{~A}$ & $\begin{array}{l}\text { Startup and Restart of Nuclear } \\
\text { Facilities }\end{array}$ & $12 / 28 / 98$ & revised & Replaced O 425.1 \\
\hline $\mathrm{O} 430.1 \mathrm{~A}$ & Life Cycle Asset Management & $10 / 14 / 98$ & revised & $\begin{array}{l}\text { The following } \\
\text { directives were } \\
\text { deleted or } \\
\text { consolidated into this } \\
\text { order: } 430.1 \text {, } \\
\text { 1332.1A, } 4010.1 \mathrm{~A} \text {, } \\
4300.1 \mathrm{C}, 4320.1 \mathrm{~B} \text {, } \\
4320.2 \mathrm{~A}, 4330.4 \mathrm{~B} \text {, } \\
4330.5,4540.1 \mathrm{C} \text {, } \\
4700.1,4700.3 \text {, } \\
4700.4,5700.2 \mathrm{D}, \\
5820.2 \mathrm{~A}, 6430.1 \mathrm{~A}\end{array}$ \\
\hline $0440.1 \mathrm{~A}$ & $\begin{array}{l}\text { Worker Protection Management for } \\
\text { DOE Federal and Contractor } \\
\text { Employees }\end{array}$ & $3 / 27 / 98$ & revised & Replaced O 440.1 \\
\hline $\begin{array}{l}\mathrm{M} 251.1- \\
1 \mathrm{~A}\end{array}$ & Directives Management System & $1 / 30 / 98$ & revised & Replaced M 251.1-1 \\
\hline G 420.1-1 & $\begin{array}{l}\text { Recruiting, Hiring, \& Retaining High } \\
\text { Quality Technical Staff }\end{array}$ & $12 / 10 / 98$ & new & \\
\hline
\end{tabular}


1998 Annual Report to Congress

\begin{tabular}{|c|c|c|c|c|}
\hline Directive & Title & Date & $\begin{array}{l}\text { New/ } \\
\text { Revised }\end{array}$ & Comment \\
\hline $\begin{array}{l}\text { STD-1120- } \\
98\end{array}$ & $\begin{array}{l}\text { Integration of Environment, Safety, } \\
\text { and Health into Facility Disposition } \\
\text { Activities Volume } 1 \text { of } 2 \text { and Volume } 2 \\
\text { of } 2\end{array}$ & $5 / 98$ & new & \\
\hline $\begin{array}{l}\text { STD-1128- } \\
98\end{array}$ & $\begin{array}{l}\text { Guide of Good Practices for } \\
\text { Occupational Radiological Protection } \\
\text { in Plutonium Facilities }\end{array}$ & $6 / 98$ & new & \\
\hline $\begin{array}{l}\text { STD-3022- } \\
98\end{array}$ & HEPA Filter Test Program & $5 / 98$ & new & $\begin{array}{l}\text { Superseded } \\
\text { DOE NE F 3-42 }\end{array}$ \\
\hline $\begin{array}{l}\text { DP-STD- } \\
3023-98\end{array}$ & $\begin{array}{l}\text { Guidelines for Risk-Based } \\
\text { Prioritization of DOE Activities }\end{array}$ & $4 / 98$ & new & \\
\hline
\end{tabular}




\section{Appendix B \\ Site Visits Supported by the Department in 1998}

\section{Argonne National Laboratory}

On September 23, 1998, the Board's staff visited Argonne National Laboratory to attend the Department's Policy 450.5 implementation workshop.

\section{Albuquerque}

- On January 12-14, 1998, the Board's staff visited Albuquerque to attend meeting on the Hazardous Analysis Report Standard.

- On February 9-12, 1998, the Board's staff visited Albuquerque to participate in the Integrated Safety Management - Lessons Learned Workshop.

- On March 17-20, 1998, the Board's staff visited Albuquerque to attend a Plutonium Storage Standard Working Group meeting.

- On April 1, 1998, the Board's staff visited Albuquerque for a briefing on the W79 Nuclear Explosive Safety Study Issues.

- On April 6-7, 1998, the Board's staff visited Albuquerque for W79 Nuclear Explosive Safety Study Issues.

- On April 13-15, 1998, the Board's staff visited Pantex and Albuquerque to review pit storage issues and the integrated pit storage program plan.

- On May 6-8, 1998, the Board's staff visited Albuquerque to review nuclear explosive safety change control.

- On May 11-15, 1998, the Board's staff visited Albuquerque to review project management.

- On June 9-10, 1998, the Board's staff visited Albuquerque to attend the Nuclear Explosive Safety Evaluation meeting.

- On July 6-9, 1998, the Board's staff visited Albuquerque to attend the lightning protection team meeting and review W62. 


\section{Annual Report to Congress}

- On July 13-14, 1998, the Board's staff visited Albuquerque to review the stockpile management.

- On July 27-28, 1998, the Board's staff visited Albuquerque to attend a meeting on target levels of controls.

- On August 4-7, 1998, the Board's staff visited Albuquerque to observe the Transportation Basis for Interim Operations Upgrade meeting.

- On October 7-9, 1998, the Board's staff visited Albuquerque to attend the senior managers meeting.

- On November 2-4, 1998, a Board staff member accompanied a Board member to Albuquerque.

- On November 3-6, 1998, the Board's staff visited Albuquerque to observe the Chemical Safety Issues Workshop.

- On November 19-20, 1998, the Board's staff visited Albuquerque to discuss the integrated weapons activity plan.

- On December 14-16, 1998, the Board's staff visited Albuquerque to discuss the integrated pit storage program plan.

\section{Amarillo}

- On July 15-17, 1998, the Board's staff visited Amarillo to review stockpile management.

\section{Hanford}

- On January 20-23, 1998, the Board's staff visited Hanford to attend Tank Waste Remediation System Gas Release Events Experts Workshop.

- On January 20-23, 1998, the Board's staff visited Hanford to observe Integrated Safety Management System Phase I Verification for K-Basins.

- On January 21-22, 1998, the Board's staff visited Hanford to discuss the January 7th, water leak at N-Basin. 
- On January 26-29, 1998, the Board's staff visited Hanford to observe Integrated Safety Management Systems Verification Review for K-basins.

- On February 2-5, 1998, the Board's staff visited Hanford to review engineering, design, and licensing activities related to the Spent Nuclear Fuel Project.

- On February 9-13, 1998, the Board's staff visited Hanford to review the tank waste remediation projects.

- On February 17-19, 1998, the Board's staff visited Hanford to review criticality safety at the Plutonium Finishing Plant.

- On March 30 - April 2, 1998, the Board visited the Hanford site to review the status of spent nuclear fuel and the Plutonium Finishing.Plant.

- On May 12-15, 1998, the Board's staff visited Hanford to observe the Operational Readiness Review at the 233-S Facility.

- On May 26-28, 1998, the Board's staff visited Hanford to review plutonium stabilization at the Plutonium Finishing Plant

- On June 8-12, 1998, the Board's staff visited Hanford to review the Hanford Chemical Safety program.

- On June 8-11, 1998, the Board's staff visited Hanford to observe the acceptance testing of the K-Basin Integrated Water Treatment System.

- On June 29 - July 1, 1998, the Board's staff visited Hanford to review the Spent Nuclear Fuel program.

- On June 29 - July 1, 1998, the Board's staff visited Hanford to review the multi-canister overpack design and fabrication issues, runaway reactions during cold vacuum drying and status of sub-projects.

- On July 6-9, 1998, the Board's staff visited Hanford to review tank waste remediation systems and Tank C-106's waste retrieval.

- On July 9, 1998, Hanford provided the Board a semi-annual briefing on the status of the Board's Recommendation 92-4. 
- On August 3-7, 1998, the Board's staff visited Hanford to support the Board's public meeting and review the K-Basins Integrated Water Treatment System.

- $\quad$ On August 4-5, 1998, the Board visited Hanford to discuss the Plutonium Finishing Plant, integrated safety management systems, and spent nuclear fuel.

- On August 5-6, 1998, the Board's staff visited Hanford to review integrated water treatment system factory performance test.

- On August 31 - September 4, 1998, the Board's staff visited Hanford Site to observe the Tank C-106 Operational Readiness Review.

- On September 9-11, 1998, the Board's staff visited Hanford Site to observe the activities at the Plutonium Finishing Plant.

- On September 28 - October 2, 1998, the Board's staff visited Hanford to review the spent nuclear fuel project multi-canister overpack issues and safety analysis report efforts.

- On October 5-8, 1998, the Board's staff visited Hanford to review the 94-1 program at the Plutonium Finishing Plant.

- On October 27-30, 1998, the Board's staff visited Hanford to review the Plutonium Finishing Plant.

- On November 30 - December 4, 1998, a Board consultant visited Hanford to observe the Operational Readiness Review at the Plutonium Finishing Plant.

Idaho National Engineering and Environmental Laboratory

- On March 9-13, 1998, the Board's staff visited Idaho National Engineering and Environmental Laboratory to review work planning and implementation.

- On May 5-6, 1998, the Board's staff visited Idaho National Engineering and Environmental Laboratory to observe the Uranium-233 System Requirements Review.

- On June 22-25, 1998, the Board's staff visited Idaho National Engineering and Environmental Laboratory to attend the 97-1 Technical Team meeting. 
- On August 18-20, 1998, the Board's staff visited Idaho Operations Office to observe the Recommendation 97-2 Technical meeting with the Criticality Safety Support Group.

- On October 6-7, 1998, the Board's staff visited Idaho National Engineering and Environmental Laboratory to participate in the Technical Team meeting concerning the safe storage of uranium-233.

- On November $16-20,1998$, the Board's staff visited Idaho for the mixed waste treatment project design review.

- On December 9-11, 1998, the Board's staff accompanied a Board member to Idaho.

\section{Lawrence Livermore National Laboratory}

- On January 8, 1998, the Board's staff visited Lawrence Livermore National Laboratory to review the status of the W79 Hazard Analysis Report and the Nuclear Explosive Hazard Assessment.

- On January 14-15, 1998, the Board's staff visited Lawrence Livermore National Laboratory to review the status of B332 restart activities.

- On March 23-26, 1998, the Board's staff visited Lawrence Livermore National Laboratory to observe the confirmation team review of Lawrence Livermore National Laboratory work smart standards.

- On April 20-24, 1998, the Board's staff visited Lawrence Livermore National Laboratory to review Building 332 resumption.

- On May 1, 1998, the Board was briefed on Lawrence Livermore National Laboratory's work smart standards and integrated safety management systems.

- On June 15-19, 1998, the Board's staff visited Lawrence Livermore National Laboratory to support a Board member's visit.

- On June 16, 1998, the Board visited Lawrence Livermore National Laboratory to discuss integrated safety management and the work smart standards process.

- On July 21-24, 1998, the Board's staff visited Lawrence Livermore National Laboratory to observe Building 332 resumption activities. 
- On August 24-28, 1998, the Board's staff visited Lawrence Livermore National Laboratory to review Building 332.

- On August 26, 1998, the Board visited Lawrence Livermore National Laboratory to review Building 332 resumption status, and receive updates on work smart standards.

- On December 2-3, 1998, the Board's staff visited Lawrence Livermore National Laboratory to review $\mathrm{Y} 2 \mathrm{~K}$ issues for multiple defense nuclear facilities throughout the complex.

\section{Lawrence Berkeley}

- On April 17, 1998, the Board and the Department reviewed the Nuclear Regulatory Commission pilot at Lawrence Berkeley National Laboratory.

\section{Los Alamos National Laboratory}

- On January 13-16, 1998, the Board's staff visited Los Alamos National Laboratory to observe Building 332 restart planning.

- On February 17-20, 1998, the Board's staff visited Los Alamos National Laboratory to attend a lightning safety seminar.

- On February 24-26, 1998, the Board's staff visited Los Alamos National Laboratory to review the ARIES demonstration project.

- On March 11-12, 1998, the Board visited Los Alamos National Laboratory to exchange information with the Department on the status of various site activities.

- On March 16-20, 1998, the Board's staff visited Los Alamos National Laboratory to observe a Plutonium Focus Area Technical Advisory Panel review of the Board's Recommendation 94-1 core program and combustibles work.

- On April 14-17, 1998, the Board's staff visited Los Alamos National Laboratory for a construction management review, to review progress in improving work smart standards, and review DX Vessel design.

- On April 27-30, 1998, the Board's staff visited Los Alamos National Laboratory to observe TA-18 criticality safety. 
- On April 27 - May 1, 1998, the Board's staff visited Los Alamo National Laboratory to observe a semiannual meeting of the External Review Committee for an overview of accelerator production of tritium.

- On May 11-14, 1998, the Board's staff Technical Director visited Los Alamos National Laboratory.

- On May 11-15, 1998, the Board's staff visited Los Alamos National Laboratory to review project management and integrated safety management.

- On May 18-20, 1998, the Board's staff visited Los Alamos National Laboratory to support a Board member's visit.

- On May 26, 1998, the Board was briefed by the Department on Los Alamos National Laboratory project management.

- On June 2-5, 1998, the Board's staff visited Los Alamos National Laboratory to review contents and actions for the site assessment report for Recommendation 97-1.

- On July 15-17, 1998, the Board's staff visited Los Alamos National Laboratory to review the seismic design criteria.

- On July 20-23, 1998, the Board's staff visited Los Alamos National Laboratory to review dynamic and experiments.

- On August 17-21, 1998, the Board's staff visited Los Alamos National Laboratory to observe the Work Planning/Worker Protection review.

- On August 17-21, 1998, the Board's staff visited Los Alamos National Laboratory to review integrated safety management at Los Alamos Neutron Science Center and Los Alamos Criticality Experiment Facility

- On September 14-18, 1998, the Board's staff visited Los Alamos National Laboratory to review integrated safety management at the weapons engineering tritium facility.

- On September 17, 1998, the Board met with the Los Alamos National Laboratory project management advisory panel. 
- On September 28 - October 2, 1998, the Board's staff visited Los Alamos National Laboratory observe the External Review Committee meeting concerning accelerator production of tritium.

- On October 5-8, 1998, the Board's staff visited Los Alamos National Laboratory to review integrated safety management at the weapons engineering tritium facility.

- On October 19-23, 1998, the Board's staff visited Los Alamos National Laboratory to review construction project management at Albuquerque and Los Alamos National Laboratory.

\section{Mound Site}

- On May 26-28, 1998, the Board's staff visited Mound to review the radiological protection program.

\section{Nevada Test Site}

- On January 12-16, 1998, the Board's staff visited Nevada Test Site to attend the National Spent Nuclear Fuel Project Semi-Annual Strategy meeting.

- On January 20-23, 1998, the Board's staff visited Nevada Test Site to attend the Stagecoach Safety Evaluation panel.

- On February 9, 1998, the Board's staff visited Nevada Test Site to attend a review of the use of electrical testers at Nuclear Test Site and to hold quality assurance discussions.

- On February 23-26, 1998, the Board's staff visited Nevada Test Site to observe the UIA Emergency Drill.

- On March 16-17, 1998, the Board's staff visited Nevada Test Site to attend a preCommunity Relations Plan meeting inspection tour and observe exercise Stagecoach.

- On April 27 - May 1, 1998, the Board's staff visited Nevada Test Site to observe an internal safety review. (Bagpipe/Clarinet Sep)

- On May 11-13, 1998, the Board's staff visited the Nevada Test Site to address site-wide issues including integrated safety management. 
- On May 18-21, 1998, the Board's staff visited the Nevada Operations Office to participate in the Department's Defense Program Staffing Study.

- On July $22-24,1998$, the Board's staff visited the Nevada Test Site to attend a community relations plan meeting.

- On July 27-31, 1998, the Board's staff visited the Nevada Test Site to review the BAGPIPE sub-critical experiment.

- On August 31-September 1, 1998, the Board's staff visited Nevada Test Site to observe CIMARRON safety evaluation panel meeting.

\section{Oakland}

- On September 29 - October 2, 1998, the Board's staff visited Oakland to observe Defense Program's staffing workshop follow-on meeting.

\section{Qak Ridge}

- On January 6-9, 1998, the Board's staff visited Oak Ridge Y-12 Enriched Uranium Operations restart preparations.

- On January 21-23, 1998, the Board's staff visited Oak Ridge to attend DP-20 Enriched Uranium Operations restart biweekly meeting at the Y-12 facility.

- On January $21-23,1998$, the Board's staff visited Oak Ridge to review criticality safety of uranium deposits at East Tennessee Technology Park.

- On February 3-5, 1998, the Board's staff visited Oak Ridge to review implementation of safety controls for Enriched Uranium Operations resumption.

- On February 17-19, 1998, the Board's staff visited Oak Ridge to review the implementation of safety basis controls (ventilation and high-efficiency particulate air filter systems related) for Enriched Uranium Operations restart.

- On February 23-27, 1998, the Board's staff visited Oak Ridge for a review of the Nuclear Criticality Safety Program at Oak Ridge National Laboratory and observe the Enriched Uranium Operations restart preparations at Y-12.

- On February 25-27, 1998, the Board's staff visited Oak Ridge for a review of the Integrated Safety Management Systems at Y-12. 


\section{Annual Report to Congress}

- On March 2-6, 1998, the Board's staff visited Oak Ridge to observe the Enriched Uranium Operations restart preparations.

- $\quad$ On March 9-13, 1998, the Board's staff visited Oak Ridge to observe Lockheed-Martin Operation Readiness Review for the Enriched Uranium restart phase A1 at Y-12 plant.

- On March 19-20, 1998, the Board's staff visited Oak Ridge to attend an Oak Ridge and Lockheed-Martin Senior Management meeting.

- On April 8-9, 1998, the Board's staff visited Oak Ridge to review the Uranium-233 Technical Standard and other Recommendation 97-1 Implementation Plan activities.

- On April 14-16, 1998, a Board Staff member visited Oak Ridge to review enriched uranium operation restart preparations at $\mathrm{Y} 12$.

- On April 20-22, 1998, the Board's staff visited Oak Ridge to observe the Planning Workshop on Phase B Restart of Enriched Uranium Operations.

- On May 4-8, 1998, the Board's staff visited Oak Ridge to observe the Operational Readiness Review for Enriched Uranium Operations.

- On April 8-10, 1998, the Board's staff visited Oak Ridge to review ventilation issues at Building 9212.

- On April 14-16, 1998, a Board's staff member visited Oak Ridge to review enriched uranium operation restart preparations at Y-12.

- On April 22, 1998, the Board's staff visited Oak Ridge to observe the Department/Lockheed-Martin planning workshop on the Phase B restart of enriched uranium operations.

- $\quad$ On April 27 - May 1, 1998, the Board's staff visited Oak Ridge to review enriched uranium operation restart preparations at $\mathrm{Y}-12$.

- On May 4-8, 1998, the Board's staff visited Oak Ridge to observe the Operational Readiness review for enriched uranium operations.

- On May 11-15, 1998, the Board's staff visited Oak Ridge to observe the Enriched Uranium Operations Phase A-1 Operational Readiness review. 
- On May 13-15, 1998, the Board's staff visited Oak Ridge to review the Department's deactivation and decommissioning readiness assessment at K-25.

- On May 19-21, 1998, the Board's staff visited Oak Ridge to review enriched uranium operations closure packages.

- On May 26-29, 1998, the Board's staff visited Oak Ridge to review closure issues for enriched uranium operations at $\mathrm{Y}-12$.

- On June $1-4,1998$, the Board's staff visited Oak Ridge to review the enriched uranium closure packages and the enriched uranium operation restart preparations.

- $\quad$ On June 9-11, 1998, the Board's staff visited Oak Ridge to review generic site issues and to review Buildings 3019 and 9212 .

- On June 10-12, 1998, the Board's staff visited Oak Ridge to review potential welding problems.

- On June 29 - July 1, 1998, the Board's staff visited Oak Ridge to review identification of safety basis controls and their implementation for various Y-12 Phase A2 enriched uranium operations.

- On July 6-9, 1998, the Board's staff visited Oak Ridge to review identification of safety basis controls and their implementation for various Y-12 Phase A2 enriched uranium operations.

- On July $13-16,1998$, the Board's staff visited Oak Ridge to attend the Enriched Uranium Operation Lessons Learned Workshop.

- On July 13-17, 1998, the Board's staff visited Oak Ridge to observe integrated safety management system verification at $\mathrm{Y}-12$.

- On July 20-22, 1998, the Board's staff visited Oak Ridge to review the Uranium-233 standard technical issues.

- On August 3-7, 1998, the Board's staff visited Oak Ridge to observe the integrated safety management system verification review.

- On August 10-13, 1998, the Board's staff visited Oak Ridge to attend the uranium-233 technical team meeting. 
- $\quad$ On August 10-14, 1998, the Board's staff visited Oak Ridge to observe the Y-12 enriched uranium operation phase A-2 restart.

- On August 25-27, 1998, the Board's staff visited Oak Ridge to observe the Y-12 Lithium Hydride Production Facility and upgrade prioritization.

- On September 8-11, 1998, the Board's staff visited Oak Ridge to review the Y-12 enriched uranium operation phase $\mathrm{A} 2$ restart.

- On September 14-17, 1998, the Board's staff visited the Oak Ridge to review the enriched uranium phase $\mathrm{A} 2$ restart controls implementation.

- On September 15-18, 1998, the Board's staff visited Oak Ridge to review Building 9206.

- On September 21-23, 1998, the Board's staff visited Oak Ridge to review the 97-2 deliverables and discuss the Y-12 criticality accident alarm system.

- On October 19-23, 1998, the Board's staff visited Oak Ridge to discuss with Lockheed Martin Energy Systems operational readiness review for the enriched uranium phase A2 restart.

- On November 4-6, 1998, the Board's staff visited Oak Ridge to review ventilation airborne and flooding issues, as well as enriched uranium operations Phase A2 restart.

- On November 10-13, 1998, the Board's staff visited Oak Ridge to observe the operational readiness review for enriched uranium operations Phase A2.

- On November 17-19, 1998, the Board's staff visited Oak Ridge to participate in the Technical Team meeting on the safe storage of uranium-233.

- On November 18-19, 1998, the Board's staff visited Oak Ridge to review the inspection program details for safe storage of Uranium-233.

- On December 7-10, 1998, the Board's staff visited Oak Ridge for a chemical safety review.

- On December 7-11, 1998, the Board's staff visited Oak Ridge for a worker protection review. 
- On December 16-18, 1998, the Board's staff visited Oak Ridge to support a Board member's visit.

\section{Pacific Northwest Laboratory}

- On June 8-12, 1998, the Board's staff visited Pacific Northwest National Laboratory to observe the Department's Integrated Safety Management verification.

\section{Pantex Plant}

- On January 26-30, 1998, the Board's staff visited Pantex for review of site transportation and packaging.

- On January 26-30, 1998, the Board's staff visited Pantex to review seismic requirements and pit storage.

- On January 27-29, 1998, the Board's staff visited Pantex to review response to reporting requirements on lightning protection.

- $\quad$ On January 27-29, 1998, the Board's staff visited Pantex to participate in W87 LEP/ASSET meetings.

- On January 5-8, 1998, the Board's staff visited Pantex to observe Practice 2 Dismantlement of W79.

- On January 16,1998 , the Board's staff visited Pantex to participate in W87 LEP/ASSET meetings.

- On February 19-20, 1998, the Board's staff visited Pantex to review the Transportation Basis for Interim Operations document.

- $\quad$ On February 23-27, 1998, the Board's staff visited Pantex to observe the W79 NESS.

- On February 25-27, 1998, the Board's staff visited Pantex to attend meeting on the lightning protection systems.

- On March 2-6, 1998, the Board's staff visited Pantex to observe the W79 NESS.

- On March 9-13, 1998, the Board's staff visited Pantex to observe the W79 NESS. 
- On March 17-19, 1998, the Board's staff visited Pantex to attend a structural/seismic review.

- On March 23-27, 1998, the Board's staff visited Pantex to observe the W79 NESS.

- On April 6-10, 1998, the Board's staff visited Pantex to observe the B61-11 nuclear explosive safety evaluation.

- On April 13-15, 1998, the Board's staff visited Pantex and Albuquerque to review pit storage issues and the integrated pit storage program plan.

- On April 13-17, 1998, the Board's staff visited Pantex to observe the Building 61-11 Nuclear Explosive Safety Evaluation.

- On April 20-22, 1998, the Board's staff visited Pantex for a briefing on the onsite movement.

- On May 26-29, 1998, the Board's staff visited Pantex to observe the operational readiness review of Building 12-116.

- On June 15-19, 1998, the Board's staff visited Pantex to review the W-62 Nuclear Explosive Safety Study revalidation.

- On June 22-26, 1998, the Board's staff visited Pantex to observe the Operational Readiness Review of Building 12-116.

- On July 27-31, 1998, the Board's staff visited Pantex to observe the Integrated Safety Management Verification review.

- On July 27-31, 1998, the Board's staff visited Pantex to observe the Pit Storage Container Independent Design review.

- On June 29-30, 1998, the Board's staff visited Pantex to review analytical models.

- On July 30-31, 1998, the Board's staff visit Pantex to participate in the W-87 Life Extension Program Senior Managers meeting.

- On August 3-7, 1998, the Board's staff visited Pantex for the Building 12-116 design review, and to attend the Liquid Waste Disposal and Lighting Protection System meeting. 
- On August 17-21, 1998, the Board's staff visited Pantex to review the Electrical Equipment Control Program Master Nuclear Explosive Safety Study.

- On August 24-28, 1998, the Board's staff visited Pantex to observe the W-56 Single Integrated Readiness Review and Electrical Tester Milestone review.

- On August 24-28, 1998, the Board's staff visited Pantex to observe the Integrated Safety Management Systems Verification and to conduct a worker protection review.

- On August 31 - September 4, 1998, the Board's staff visited Pantex to observe the Integrated Safety Management System Verification and to conduct a worker protection review.

- On August 31- September 4, 1998, the Board's staff visited Pantex to observe the Single Internal Readiness Review and the Electrical Equipment Nuclear Explosive Safety Master study.

- On September 8-11, 1998, the Board's staff visited Pantex to attend the AL-R8 Project Management Review.

- On September 14-18, 1998, the Board's staff visited Pantex to review justification for insensitive high-explosive controls for nuclear explosive operations.

- On September 14-18, 1998, the Board's staff visited Pantex to observe the emergency response exercise.

- On September 17-18, 1998, the Board's staff visited Pantex to review justification for insensitive high-explosive controls for nuclear explosive operations and discuss the $\mathrm{Y} 2 \mathrm{~K}$ program.

- On October 5-9, 1998, the Board's staff visited Pantex observe the W87/W62 Hazards Analyses Controls Identification and Implementation review.

- On October 12-16, 1998, the Board's staff visited Pantex to observe the Lightning Protection Project Team Meeting.

- On October 19-23, 1998, the Board's staff visited Pantex to observe the W-56 Adequacy review and discuss the B53 end cap. 
- On October 26-29, 1998, the Board's staff visited Pantex to review insensitive high explosive controls and $\mathrm{Y} 2 \mathrm{~K}$.

- On November 3-6,1998, the Board's staff visited Pantex to observe the W-56 milestone review.

- On November 11-13, 1998, the Board's staff visited Pantex to observe the W-56/B53 hazards analysis and implementation review.

- On November 16-20, 1998, the Board's staff visited Pantex to discuss the W-56 Nuclear Explosive Safety Study.

- On November 16-20, 1998, the Board's staff visited Pantex to discuss the W62 Hazard Analysis Report walk down.

- On November 30 - December 4, 1998, the Board's staff visited Pantex to observe the W-62 Hazard Analysis Report development process.

- On November 30 - December 4, 1998, the Board's staff visited Pantex to observe the W56 Nuclear Explosive Safety Study.

- On December 7-11, 1998, the Board's staff visited Pantex to observe the W-56 Safety Study.

- On December 7-11, 1998, the Board's staff visited Pantex to observe the PT 4174 Safety Study.

- On December 16-18, 1998, the Board's staff visited Pantex to observe the W56 Readiness Assessment.

\section{Princeton Plasma National Laboratory}

- On June 9-12, 1998, the Board's staff visited Princeton Plasma National Laboratory to observe the Department's Integrated Safety Management Verification.

\section{Rocky Flats}

- On January 7, 1998, the Board's staff visited Rocky Flats to tour staging facility for plutonium stabilization and packaging equipment. 
- On January 12-16, 1998, the Board's staff visited Rocky Flats to observe the Integrated Safety Management System Verification.

- On January 20-23, 1998, the Board's staff visited Rocky Flats to observe the Integrated Safety Management System Verification.

- On April 8-10, 1998, the Board's staff visited Rocky Flats to review radiological sabotage and material storage.

- On April 27 - May 1, 1998, the Board's staff visited Rocky Flats to observe the Emergency Response Exercise READY-98.

- On May 11-15, 1998, the Board's staff visited Rocky Flats to observe the Building 771 Basis for Operations Implementation Validation Review.

- On June 22-25, 1998, the Board's staff visited Rocky Flats to observe the Work Planning and Worker Protection Review.

- On June 29 - July 1, 1998, the Board's staff visited Rocky Flats to review the status of Recommendation 94-3.

- On August 24-28, 1998, the Board's staff visited Rocky Flats to observe the Tap and Drain Readiness Assessment.

- On October 6-8, 1998, the Board's staff visited Rocky Flats to review site activities.

- On October 7-9, 1998, the Board's staff visited Rocky Flats to interview criticality safety operations staff.

- On October 26-29, 1998, the Board's staff visited Rocky Flats to review the conduct of maintenance and $\mathrm{Y} 2 \mathrm{~K}$.

\section{Sandia National Laboratory}

- On March 9-13, 1998, the Board's staff visited Sandia National Laboratory to attend the Department's 1998, Enhanced Surveillance Program Review.

- On November 2-6, 1998, the Board's staff visited Sandia National Laboratory to observe the Integrated Safety Management Verification Review. 


\section{Savannah River Site}

- On January 6-8, 1998, the Board's staff visited Savannah River to attend H-Canyon Phase II Startup Review.

- On January 6-7, 1998, the Board's staff visited Savannah River to address the Actinide Packaging and Storage Facility structural/seismic issues.

- On January 13-15, 1998, the Board's staff visited Savannah River to attend the Safety Management Implementation Team Working meeting on integrated safety management system description guidance.

- On January $12-15,1998$, the Board's staff visited Savannah River to attend the HCanyon Phase II Startup Review.

- On February 4-6, 1998, the Board's staff visited Savannah River for a review of the Actinide Packaging and Storage Facility and other potential plutonium storage facilities.

- On February 9-10, 1998, the Board's staff visited Savannah River Site to attend a InTank Precipitation follow-up brief.

- On March 2-4, 1998, the Board's staff visited Savannah River to attend the 97-1 Technical Team meeting.

- On March 16-20, 1998, the Board's staff visited Savannah River Site to attend a chemical panel briefing.

- On March 24-26, 1998, the Board's staff visited Savannah River to observe the HCanyon Phase II.

- On April 14-15, 1998, two Board members visited the Savannah River Site to review geotechnical/seismic issues at construction projects and to review facilities for possible material storage uses.

- On April 14-17, 1998, the Board's staff visited Savannah River to observe the HCanyon First Cycle Readiness Assessment.

- On April 20-24, 1998, the Board's staff visited Savannah River Site to review the Tank Farm, Tritium and the In-Tank Precipitation. 
- $\quad$ On May 4-7 1998, the Board's staff visited Savannah River's Actinide Packaging and Storage Facility for a geotechnical review.

- On June 1-4, 1998, the Board's staff visited Savannah River to view presentations on the Tritium Extraction Facility preliminary design.

- On June 1-5, 1998, the Board's staff visited Savannah River to observe the Defense Waste Processing Facility's Integrated Safety Management System Phase II Verification by the Federal Executive Board.

- On June 8-12, 1998, the Board's staff visited Savannah River to observe the Defense Waste Processing Facility Integrated Safety Management Phase II Verification.

- On June 10-12, 1998, the Board's staff visited Savannah River to review Americium/Curium Stabilization program.

- On July 13, 1998, the Board's staff visited Savannah River to review the in-tank precipitation, high-level waste farms and the H-Canyon.

- On July 21-23, 1998, the Board's staff visited the Savannah River to review the status and design of the actinide packaging and storage facility.

- On August 19, 1998, the Board's staff visited Savannah River for the Actinide Packaging and Storage Facility design and review.

- $\quad$ On August 24-28, 1998, the Board's staff visited Savannah River to review the Actinide Packaging and Storage Facility and the generic ground motion detector.

- On August 31- September 1, 1998, the Board's staff visited Savannah River review high level waste and to discuss $\mathrm{H}$-Canyon issues.

- On September 15-17, 1998, the Board's staff visited the Savannah River Site to discuss americium/curium stabilization and the H-Canyon Phase III startup.

- On September $21-24,1998$, the Board's staff visited Savannah River to observe the 9303 Training and Qualification Program Phase I assessment.

- On September 22-23, 1998, the Board's staff visited Savannah River to review criticality issues at the H-Canyon. 
- On October 19-22, 1998, the Board's staff visited Savannah River to review in-tank precipitation, high-level waste and other issues.

- On November 16-19, 1998, the Board's staff visited Savannah River to discuss the deactivation and decommissioning, headquarter/field committee meeting.

- On December 15-16, 1998, the Board's staff visited Savannah River to review tritium facilities, the consolidated safety analysis report, and fire protection.

- On December 16-18, 1998, the Board's staff visited Savannah River to follow up on Actinide Packaging Storage Facility and K Area Pu storage and review emerging high level waste tank integrity questions.

\section{Waste Isolation Pilot Project}

- On January 13-16, 1998, the Board's staff visited Waste Isolation Pilot Project to observe emergency preparedness drill during contractor Operational Readiness Review.

- On March 2-6, 1998, the Board's staff visited Waste Isolation Pilot Project to observe the Operational Readiness Review.

- On April 15-17, 1998, the Board's staff visited Waste Isolation Project Project to review the maintenance/reliability of waste hoist.

- On September 14-17, 1998, the Board's staff visited Waste Isolation Pilot Project to observe Phase II of the integrated safety management system verification. 


\section{Appendix C \\ Key Department/Board Correspondence in 1998}

\section{From the Board to the Department:}

- On January 8, 1998, the Board forwarded a letter to the Secretary concurring with the startup of salt stabilization in Building 707 at Rocky Flats. The Board agrees that adequate preparations and training has been completed for the safeguarding of public health and safety.

- On January 13, 1998, the Board sent a letter to the Assistant Secretary for Defense Programs forwarding a staff issue report on concerning the resumption of work at the Chemistry and Metallurgy Research (CMR) building at the Los Alamos National Laboratory (LANL).

- On January 16,1998 , the Board forwarded a letter to the Department commenting on the status of the 96-1 Implementation Plan for In-Tank Precipitation. The Board commended the Department on its efforts to understand the In-Tank Precipitation process chemistry and its resolve to reevaluate its action plan and solve outstanding technical questions.

- On January 29, 1998, the Board forwarded a letter to the Secretary discussing the disposition of plutonium-bearing residues at the Rocky Flats site and other defense nuclear sites to the Waste Isolation Processing Plant. The Board that they would look favorably on the timely movement of all such residues from defense nuclear sites to Waste Isolation Processing Plant.

- On January 30, 1998, the Board forwarded a letter to the Assistant Secretary for Defense Programs with an enclosure summarizing issues identified during a December 15-19, 1997, Board's staff visit to the Enriched Uranium Operations (EUO) restart preparations at the Y-12 Plant at Oak Ridge. Many of the issues summarized have been previously communicated to the Department but progress to resolve them has been slow. The Board is committed to working with the Department and Lockheed Martin Energy Systems for the safe and timely restart of the Enriched Uranium Operation.

- On January 30, 1998, a Board member forwarded a letter to the Acting Director of the Nuclear Material Stabilization Task Group noting the Department's excellent briefing on the progress with Uranium 233 related actions under the Implementation Plan for recommendation 97-1. 
- On February 6, 1998, the Board sent a letter to the Assistant Secretary for Defense Programs forwarding a staff issue report regarding the phase-out activities for Building 9206 at the Y-12 plant at Oak Ridge. The Board requested a copy of the Department's phase-out plan for review once it is completed.

- On February 9, 1998, the Board forwarded a letter to the Deputy Assistant Secretary for Military Application and Stockpile Management acknowledging the receipt of the Department's December 30, 1997, letter requesting an extension for the submission of a report on facility utilization at the Pantex Plant. The Board granted the request with a submission date of February 27, 1998.

- On February 9, 1998, the Board forwarded a letter to the Secretary acknowledging the Department's response to Board inquiries into health and safety issues associated with ventilation confinement systems at defense nuclear facilities.

- On February 9, 1998, the Board forwarded a letter to the Deputy Secretary commenting on the most recent draft of Department Order 430.1A, Life Cycle Asset Management.

- On February 25, 1998, the Board sent a letter to the Under Secretary forwarding a staff issue report concerning the electrical and control systems of the Spent Nuclear Fuel Project (SNFP) at the Hanford Site. The Board highlighted concerns with the design of the battery room ventilation system and potential failure of distribution transformers manufactured by ELMA.

- On March 3, 1998, the Board forwarded a letter to the Deputy Secretary commenting on the integrated safety management workshop in Albuquerque. The Board was highly salutary of the Deputy's presentation and the abundance of attendance by Department field elements.

- On March 4, 1998, the Board forwarded a letter to the Secretary concerning the dismantlement and surveillance activities at Pantex and the Los Alamos and Lawrence Livermore National Laboratories. Enclosed was a classified report discussing the need for higher frequency sampling of high explosives in the stockpile.

- On March 11, 1998, the Board sent a letter to the Under Secretary forwarding a staff issue report concerning preparations to resume first-cycle solvent extraction operations at $\mathrm{H}$-Canyon. 
- March 18, 1998, the Board sent a letter to the Department forwarding staff issue report (enclosed) on the review of the spent nuclear fuel project at the Hanford site (trip conducted February 3-5, 1998) (Rec. 94-1).

- On March 20,1998, the Board sent a letter to the Deputy Secretary, requesting a report in sixty days on integrated safety management feedback processes.

- On March 26, 1998, the Board sent a letter to the Acting Assistant Secretary for Environmental Management requesting a report within thirty days and addressing specific actions concerning high efficiency particulate air filter safety concerns.

- On March 27, 1998, the Board sent a letter to the Deputy Secretary of Energy to report that the Board's concerns with draft Order 430.1A, Life Cycle Asset Management, have been resolved.

- On March 27, 1998, the Board forwarded a letter on the resolutions to issues concerning the draft Order 430.1A, approving it for issuance.

- On April 15, 1998, the Board sent a letter to the Under Secretary, requesting a report on the status of the Department's 94-1 Implementation Plan milestones at the Hanford Plutonium Finishing Plant and the efforts at the Hanford site to improve the readiness review process.

- On April 15, 1998, the Board sent a letter to the Secretary accepting the deletion of three milestones in the Department's 94-1 Implementation Plan for the Savannah River Site. However, the Board indicated that it expects revised commitments on other activities at the site.

- On April 15, 1998, the Board sent a letter to the Assistant Secretary for Defense Programs outlining key questions that must be addressed for closure of Board Recommendation 93-6, Maintaining Access to Nuclear Weapons Expertise.

- April 22, 1998, the Board forwarded a letter submitting observations developed by the Board's staff concerning worker protection and formality of operations at the Idaho National Engineering and Environmental Laboratory.

- April 24, 1998, the Board forwarded a letter accepting white papers concerning the Department of Energy's commitment in response to the Board's 1995 reporting requirement on R\&D Safety. 


\section{Annual Report to Congress}

- $\quad$ On April 28, 1998, the Board sent a letter to the Deputy Secretary with a Staff Issue Report enclosed, describing observations of the Work Smart Standards Process at Lawrence Livermore National Laboratory and suggesting that the Department place the work smart standards process on hold at defense nuclear facilities.

- On May 1, 1998, the Board sent a letter to the Deputy Secretary with a Staff Issue Report enclosed, noting several concerns with the draft revision to the plutonium storage standard (DOE-STD-3013).

- On May 14, 1998, the Board sent a letter to Secretary Peña noting the timeliness and overall quality of the initial site assessment reports from Idaho National Engineering and Environmental Laboratory, Los Alamos National Laboratory, and Oak Ridge National Laboratory that were completed under the 97-1 Implementation Plan for Uranium-233.

- On May 14, 1998, the Board sent a letter to Secretary Peña with a sixty day reporting requirement concerning specific questions related to external regulation.

- On June 1, 1998, the Board sent the Assistant Secretary for Defense Programs a letter requesting additional information on the process by which the Department performs change control for its nuclear explosive operations at the Pantex Plant.

- $\quad$ On June 1, 1998, the Board sent a letter to the Assistant Secretary for Defense Programs forwarding a Staff Issue Report on the Safety Evaluation Panel reviews of the BAGPIPE and CLARINET subcritical experiments at Nevada Test Site.

- On June 1, 1998, the Board sent a letter to the Secretary accepting the Implementation Plan for Recommendation 93-3.

- $\quad$ On June 3,1998, the Board sent a letter to the Deputy Secretary forwarding a review of the use of Work Smart Standards process at Los Alamos National Laboratory to identify safety-related requirements that will form the basis for its Integrated Safety Management Program.

- On June 3,1998, the Board sent a letter to the Secretary concerning reviews of the Department's preparations for the start-up of transuranic waste disposal operations at Waste Isolation Pilot Plant.

- $\quad$ On June 5, 1998, the Board sent the Secretary a letter concerning shipment of plutonium-bearing residues from Rocky Flats to Savannah River for processing in the canyons. 
- On June 10,1998, the Board sent a letter to the Secretary forwarding a set of Board's staff comments for consideration on the continued development of the uranium-233 packaging and storage standard.

- On June 12,1998, the Board sent a letter to the Assistant Secretary for Defense Programs requesting a report within 60 days concerning occurrences related to maintenance activities at the Oak Ridge Y-12 Plant.

- On June 19, 1998, the Board sent a letter to the Assistant Secretary for Defense Programs acknowledging that the most significant safety issues have been resolved for the restart of certain operations, designated Phase A1, for Enriched Uranium Operations in Buildings 9212 and 9215 , and at the Y-12 Plant. The Board requested a briefing on the path forward for follow-on phases $\mathrm{A} 2$ and $\mathrm{B}$.

- On June 25, 1998, the Board sent a letter to the Assistant Secretary for Defense Programs forwarding the Board's staff observations concerning expanded W-69 dismantlement operations in Building 12-64.

- On June 26, 1998, the Board sent a letter to the Under Secretary of Energy concerning the Operational Readiness Review conducted for Richland in support of decommissioning activities at the 233-S Concentration Facility at the Hanford site.

- On July 10, 1998, the Board sent a letter to the Department forwarding a report including the Board's staff observations of the stabilization of americium/curium solutions stored in F-Canyon the at Savannah River Site.

- On July 13,1998 , the Board sent a letter to the Department that forwarding a report describing their observations of plutonium stabilization at the Hanford Plutonium Finishing Plant establishing a 60-day responding requirement for addressing issues raised in the report.

- On July 22,1998 , the Board sent a letter to the Under Secretary concerning their review of the Uranium-233 system requirements document.

- On July 29, 1998, the Board sent a letter to the Acting Secretary for Environmental Management forwarding a list of Recommendation 94-2 deliverables the Board has accepted for closure. 


\section{Annual Report to Congress}

- On August 10, 1998, the Board sent a letter to the Manager of the Savannah River Operations Office forwarding comments on a July 21,1998 , letter relating to seismic design and engineering for new construction projects at Savannah River Site.

- On August 13, 1998, the Board sent a letter to the Acting Assistant Secretary for Environmental Management accepting the revised Integrated Program Plan for Recommendation 94-3 to ensure a suitable storage location for the large quantity of plutonium material at the Rocky Flats Environmental Technology Site.

- On August 13,1998, the Board sent a letter to the Under Secretary forwarding the Staff 's review of high-level waste storage and processing, and to evaluate closure of safety issues at the Savannah River Site H-Canyon.

- $\quad$ August 24, 1998, the Board sent a letter to the Assistant Secretary for Defense Programs forwarding the Board's staff review of the anhydrous hydrogen fluoride delivery system at the Y-12 Plant.

- On August 26, 1998, the Board sent a letter to the Assistant Secretary for Defense Programs forwarding a staff trip report concerning the Department's operational readiness review of Building 12-116 at Pantex and the integrated pit storage program plan.

- On August 31, 1998, the Board sent a letter to the Departmental Representative to the Defense Nuclear Safety Board forwarding comments on the draft report entitled Project TRNG-0002, Radiological Working training.

- On September 10,1998, the Board sent a letter to the Secretary congratulating him on his appointment as Secretary of the Department of Energy and requesting a meeting.

- On September 10, 1998, the Board sent a letter to the Acting Assistant Secretary for the Office of Environment, Safety and Health requesting information on the status of the fire safety programs at defense nuclear facilities.

- On September 11,1998, the Board sent a letter to the Secretary providing selected nearterm milestones for the removal and safe stroage of spent nuclear fuel from the K-Basins at Hanford.

- On September 16,1998, the Board sent a letter to the Deputy Secretary acknowledging a June 3, 1998, letter and report on the use of feedback of operating experience to improve the safety of operations which responded to the Board's March 20, 1998, letter. 
- On September 18, 1998, the Board sent a letter to the Deputy Secretary to forward a report of the Board's staff observations of the Integrated Safety Management System Verification at the Pacific Northwest National Laboratory.

- On September 21, 1998, the Board sent a letter to the Assistant Secretary for Defense Programs forwarding a report that discusses recent seismic investigations at Los Alamos National Laboratory.

- On September 28, 1998, the Board sent a letter to the Secretary approving Recommendation 98-1, which deals with Integrated Safety Management and the Department's facilities.

- On September 30,1998, the Board sent a letter to the Secretary forwarding a draft report that responded to sixteen specific inquires from the Congress evaluating External Regulation of Defense Nuclear Facilities.

- September 30, 1998, Board letter to the Department forwarding Recommendation 98-2, Safety Management at the Pantex Plant.

- On October 8, 1998, the Board sent a letter to the Assistant Secretary for Defense Programs forwarding a report of the Board's staff trip report concerning the Holden Gas Furnace at the Y-12 Plan for information.

- On October 8, 1998, the Board sent a letter to the Acting Assistant Secretary for Environmental Management forwarding comments on the recent draft of the Radioactive Waste Management Order 435.1, and its associated manual, guidance, and technical basis documentation.

- On October 8, 1998, the Board sent a letter to the Secretary concerning the status of the Department's revisions to Recommendation 94-1 Implementation Plan, and responding to the technical update to the Implementation Plan provided to the Board on September $2,1998$.

- On October 20,1998, the Board sent a letter to the Acting Assistant Secretary for Environmental Management explaining the status of improved schedule for remediation.

- On October 27, 1998, the Board sent a letter to the Secretary complimenting the efforts taken in the completion the dismantlement of W-69 warheads at the Pantex Plant. 
- On October 30,1998, the Board sent a letter to the Secretary encouraging the continued support of the international program that compiles and analyzes data on the effects of nuclear radiation received over the years in the Soviet Union during development and structure of their nuclear weapons arsenal.

- On November 17, 1998, the Board sent a letter to the Assistant Secretary for Defense Programs forwarding a report prepared by the Board's staff concerning certain classified activities at the Los Alamos National Laboratory and requesting a report in thirty days addressing the Department's path forward for completing startup preparations.

- On November 18, 1998, the Board sent a letter to the Secretary addressing the waste management Order 435.1 and out lining a path to closure on Recommendation 94-2.

- On November 24, 1998, the Board sent a letter to the Assistant Secretary for Defense Programs forwarding observations for consideration and action concerning the year 2000 program at the Oak Ridge Y-12 Plant.

- November 27, 1998, Board letter to the Department forwarding a report addressing sixteen specific items in accordance with the National Defense Authorization Act for Fiscal Year 1998.

- November 30, 1998, Board letter to the Department forwarding three (3) staff issue reports documenting observations during a recent series of reviews at the Pantex Plant.

- On December 1, 1998, the Board sent a letter to the Department forwarding a staff issue report on the review of electrical, control, fire protection, and ventilation systems for the Cold Vacuum Drying Facility at the Hanford SNFP.

- On December 14, 1998, the Board sent a letter to the Under Secretary forwarding comments on the review of the Departments standard DOE-SAFT-0067, Criteria for Packaging and Storing Uranium-233-Bearing Materials. The Board requested a report in thirty days addressing the Departments plans for addressing the Board's comments.

- On December 17, 1998, the Board sent a letter to the Assistant Secretary for Defense Programs congratulating the Y-12 Site Office and Lockheed Martin Energy Systems on their efforts toward restart of enriched uranium operations phase A2 operation. 
- On December 21, 1998, the Board forwarded a report to the Technical Director of Environment, Safety and Health summarizing Energy Federal Contractors Group / Department of Energy Chemical Safety Issues Workshop and Mr. DiNunno's remarks to that group concerning integrated safety management.

- On December 22, 1998, the Board forwarded an issue report for consideration to the Acting Assistant Secretary for Environmental Management prepared by the Board's staff on the design of the advanced mixed waste treatment project at the Idaho National Engineering and Environmental Laboratory.

\section{From the Department to the Board:}

- On January 6, 1998, the deputy Assistant Secretary for Military Application and Stockpile Management forwarded a letter enclosing to summaries of line management's review of actions under Recommendation 93-6 Implementation Plan, these reviews covered the period of September 1 through November 30, 1997.

- On January 7, 1998, the Deputy Assistant Secretary for Military Applications and Stockpile Management sent a letter to the Board forwarding the eleventh Quarterly Report for July - September as a part of the 94-4 Implementation Plan.

- On January 7, 1998, the Manager of the Richland Operations Office forwarded a letter to the Board competing milestone 5.4.3.5d, "Letter Reporting Qualification of Rotary Mode Core Sampling System for use in Flammable Gas Tanks," of Recommendation 93-5 Implementation Plan.

- On January 9, 1998, the Secretary forwarded a letter to the Board proposing several milestone deletions from Recommendation 94-1 Implementation Plan for the Savannah River Site.

- On January 13, 1998, the Assistant Secretary for Environmental Management forwarded a letter notifying the Board that the 1997 Research and Development Plan milestone of Recommendation 94-1 Implementation Plan was completed and previously delivered.

- On January 15, 1998, the Assistant Secretary for Environmental Management forwarded a letter to the Board responding to the Board's letter of October 30,1997, on vulnerabilities associated with nuclear facility ventilation confinement systems. The Department acknowledged the vulnerabilities associated with High Efficiency Particulate Air Filter degradation from wetting during fire system testing, and reported tasking field offices to correct related problems. 
- On January 16, 1998, the Deputy Assistant Secretary for Research and Development for Defense Programs forwarded a letter to the Board acknowledging the Board's December 31 st letter concerning safety issues at Building 332, Lawrence Livermore National Laboratory. The Department will provide a briefing to the Board on a corrective action plan once it is finalized.

- On January 16, 1998, the Deputy Secretary forwarded a letter to the Board responding to the Board's letter of December 5, 1997, concerning the status of Order 430.1A, Life Cycle Asset Management, and its associated implementation guides. The Department enclosed a updated draft of Order 430.1A, an updated set of implementation guides, and cross walk requirements from the old Order 5820.2A. The Department requests written comments from the Board by February 9, 1998.

- On January 23, 1998, the Manager of the Richland Operations Office forwarded a letter to the Board fulfilling commitment 5.2.2.b, "Create a Method for Measuring Systems Engineering Implementation in TWRS Projects," of the Recommendation 92-4 Implementation Plan.

- On January 27, 1998, the Manager of the Richland Operations Office forwarded a letter to the Board transmitting the 93-5 Implementation Plan quarterly report for October through December of 1997.

- On January 27, 1998, the Acting Director of the Office of Fissile Materials Disposition forwarded a letter to the Board enclosing a report, "Strategy for the Future use and Disposition of Uranium 233: Overview," fulfilling commitment 11 of the 97-1 Implementation Plan.

- On January 29, 1998, the Assistant Secretary for Human Resources forwarded a letter to the Board enclosing the sixteenth Quarterly Report for the 93-3 Implementation Plan period ending December 31, 1997.

- On January 30,1998, the Acting Deputy Assistant Secretary for Nuclear Material and Facility Stabilization sent a letter to the Board enclosing a report, "Technical Competencies for the Safe Interim Storage and Management of U-233 at DOE Facilities," fulfilling commitment 12 of the 97-1 Implementation Plan. This report documents workers who have direct experience with handling, processing, and managing uranium-233. 
- On February 2, 1998, the Deputy Assistant Secretary for Research, Development, and Testing forwarded a letter to the Board fulfilling commitments 6.9, 6.8, and 6.2.1. milestone 1,2, and 3, of the 97-2 Implementation Plan.

- On February 2, 1998, the Manager of the Richland Operations Office forwarded a letter to the Board discussing the delay in the completion of some commitments for the 92-4 Implementation Plan.

- On February 12, 1998, the Assistant Secretary for Defense Programs forwarded a letter to the Board addressing the status of the 93-1 Implementation Plan. Enclosed are two responses to Board inquires regarding the Nuclear Explosive and Weapon Surety Directives and the Hazard Analysis Report.

- On February 20, 1998, the Deputy Assistant Secretary for Military Application and Stockpile Management forwarded a letter to the Board discussing the need for further investigations into lightening protection hazards at Pantex.

- On February 24, 1998, the Manager of the Richland Operations Office forwarded a letter to the Board enclosing six Interface Control Documents for the 92-4 Implementation Plan commitment 5.2.3.a.

- On February 24, 1998, the Deputy Secretary forwarded a letter to the Board responding to inquirers about the status of implementation of integrated safety management throughout the Department. Enclosed were eight responses from the Department's Defense Nuclear sites.

- On February 24, 1998, the Manager of Richland Operations Office forwarded a letter to the Board completing commitment, 5.2.3.a, "DOE will provide three interface control documents for TWRS privatization," of the 92-4 Implementation Plan.

- On February 27, 1998, the Deputy Assistant Secretary for Military Application and Stockpile Management forwarded a letter to the Board fulfilling a request for a report evaluating if relative hazards of operations and relative capabilities of facilities are used in determining the ultimate use of a certain building at Defense Program Sites. The report also focused on a review by the Amarillo Area Office of the W69 operations.

- On February 27, 1998, the Assistant Secretary for Environmental Management forwarded a letter to the Board enclosing the Department's Consolidated Annual Report of activities related to the implementation of the Recommendation 94-1. 


\section{Annual Report to Congress}

- On March 2, 1998, the Acting Assistant Secretary for Environmental Management forwarded to the Board a quarterly report of progress for the 94-3 integrated program.

- On March 3, 1998, the Acting Assistant Manager for High Level Waste at Savannah River sent a letter to the Board regarding changes in the Implementation Plan for the Recommendation 96-1 and the suspension of restart activities at the In-Tank Precipitation Facility.

- On March 5, 1998, the Deputy Assistant Secretary for Military Application and Stockpile Management forwarded a letter to the Board forwarding a report evaluating the Department's current Capabilities Maintenance and Improvement Project program management.

- On March 11, 1998, the Acting Assistant Secretary for Environmental Management forwarded to the Board a letter of acceptance and a compliance evaluation for the "Radiological Performance Assessment for the Z-Area Saltstone Disposal Facility."

- On March 11, 1998, the Deputy Assistant Secretary for Military Application and Stockpile Management forwarded Quarterly Report 12 to the Board for the 94-4 Implementation Plan.

- March 13, 1998, Department letter to the Board forwarding notification regarding DOE, Richland Operations Office Senior point-of-contact on Board activities.

- March 13, 1998, Department letter to the Board forwarding the consolidated response (enclosed) from DOE Kirtland and Sandia addressing concerns on integrated contractor self-assessments and oversight.

- On March 18, 1998, the Defense Programs Deputy Assistant Secretary for Research and Development forwarded a letter to the Board that addresses concerns on integrated contractor self-assessments and Department oversight at the Kirtland Area Office and Sandia National Laboratories.

- On March 19, 1998, the Acting Assistant Secretary for Environmental Management sent a letter to inform the Board that Roy J. Schepens is the new Responsible Manager for the implementation of the Recommendation 96-1.

- On March 20, 1998, the Acting Assistant Secretary for Environmental Management sent a letter to the Board to indicate that the Department would take measures to address the 
Board's concerns about the electrical, control and fire protection systems of the Hanford Spent Nuclear Fuel Project.

- On March 24, 1998, the Manager of the Idaho National Engineering and Environmental Laboratory (INEEL) forwarded the INEEL Uranium-233 Initial Site Assessment Report to the Board as the deliverable under the Implementation Plan for recommendation 97-1.

- On March 26, 1998, the Department forwarded a letter to the Board concerning the schedule for completing Milestone 5.4.3.1D "Approved Final Safety Analysis Report" of the Department's Implementation Plan on Hanford Waste Tank Characterization.

- On March 27, 1998, the Oak Ridge National Laboratory (ORNL) Site Manager forwarded to the Board the ORNL Uranium-233 Initial Site Assessment Report as the deliverable under the Implementation Plan for Recommendation 97-1.

- On March 27, 1998, the Department forwarded to the Board the Oak Ridge National Laboratory Initial Site Assessment Report for the 97-1 Implementation Plan.

- March 27, 1998, the Department sent a letter to the Board forwarding completion of milestones 5.5.6.1.a and 5.6.3.1.g (enclosed) per the 93-5 implementation plan.

- March 30,1998, Department letter to the Board forwarding completion of commitment 6.2.1, milestone 4 per the 97-2 implementation plan.

- March 30, 1998, Department letter to the Board concerning the report on the evaluation of project management at LANL.

- On March 30, 1998, the Acting Assistant Secretary for Environmental Management sent a letter to the Board informing them that the Uranium-233 Safe Storage System Requirements Document delivery would be delayed until May 29, 1998.

- On March 30, 1998, the Department sent a letter informing the Board of a 60-day delay in forwarding the System Requirements Document per the 97-1 Implementation Plan.

- April 15, 1998, the Department sent a memorandum announcing the Annual Defense Nuclear Facilities Safety Board Interface Workshop on June 17-18, 1998, for Department personnel to exchange information and to share experiences for effectively resolving safety issues raised by the Board. 
- April 16,1998, Department letter to the Board concerning its final response to the Board's letter of February 25, 1998, regarding the electrical, control and fire protection systems at Hanford.

- On April 21, 1998, the Department sent a letter to the Board forwarding the Recommendation $97-2$ quarterly status report.

- April 21, 1998, the Secretary sent a letter to the Board concerning the recently issued DOE Order 251.1A, Directives System, and its associated DOE Manual 251.1-1A.On January 8,1998 , the Board forwarded a letter to the Secretary concurring with the startup of salt stabilization in Building 707 at Rocky Flats. The Board agrees that adequate preparations and training has been completed for the safeguarding of public health and safety.

- On April 27, 1998, the Department forwarded a letter with an attached report responding to the Board's 30-day reporting requirement concerning High Efficiency Particulate Air Filter vulnerabilities.

- On April 27, 1998, the Department sent a letter forwarding a deliverable under the Implementation Plan for 92-4, Evaluate 1997 systems engineering processes existing on the Tank Waste Remediation System immobilized low-activity waste interim storage project".

- On April 29, 1998, the Department sent a letter to inform the Board of the expected date for Richland Manager approval of the tank Waste Remediation System final safety analysis report.

- On April 30, 1998, the Department forwarded a draft standard, "Criteria for Packaging and Storing U-233 Bearing Materials," as a deliverable under the Department's 97-1 Implementation Plan.

- On May 5, 1998, the Secretary sent a letter to the Board forwarding the revised Implementation Plan for 93-3, "Improving DOE Technical Capability in Defense Nuclear Facilities Programs".

- On May 5, 1998, the Secretary sent a letter to the Board informing them that the Implementation Plan for Recommendation 94-1 would be revised this year and that no changes were being made to the current management structure for 94-1. 
- On May 18, 1998, the Deputy Secretary sent a letter to the Board requesting an additional 15 days to complete a Departmental report addressing various assessments and corrective action programs that was requested by a Board letter dated March 20, 1998.

- On May 19, 1998, the Manager of the Richland Operations Office sent a letter to the Board, forwarding a baseline comparison report for the first tank retrieval system in the tank waste remediation system project and a system specification document as deliverables under the Implementation Plan for Recommendation 92-4.

- On May 21, 1998, the Acting Assistant Secretary for Environmental Management provided a quarterly progress report for the 94-2 Implementation Plan for the fourth quarter of 1997.

- On May 27, 1998, the Acting Assistant Manager of High Level Waste at Savannah River Operations Office sent a letter to the Board forwarding reports under the Recommendation 96-1 Implementation Plan.

- On May 27, 1998, the Acting Assistant Secretary for Environmental Management sent a letter to the Board documenting the completion of radiological assessments for low-level waste disposal facilities at Savannah River and Nevada in accordance with the Recommendation 94-2 Implementation Plan.

- May 27, 1998, Department letter to the Board regarding suspension of restart activities at the ITP Facility per the 96-1 implementation plan.

- On May 29, 1998, the Executive Secretary to the Federal Technical Capability Panel sent a letter to the Board listing the senior line managers who were formally designed as agents representing the heads of their organization as members of the Federal Technical Capability Panel tasked to oversee the activities outlined in the Department's 93-3 Implementation Plan.

- On June 1, 1998, the Assistant Secretary for Defense Programs sent a letter to the Board forwarding a report evaluating improvement in management of projects at Los Alamos National Laboratory in response to the Board's December 5, 1997, letter.

- On June 1, 1998, the Deputy Assistant Secretary for Military Application and Stockpile Management for Defense Programs sent a letter to the Board providing a Project Plan to resolve the lightning hazard at Pantex. 


\section{Annual Report to Congress}

- June 2, 1998, Department letter to the Board forwarding a report responding to a Board letter regarding evaluation of project management at LANL.

- June 2, 1998, Department letter to the Board forwarding material committed to at the May 7, 1998, Public Meeting on Recommendation 94-1.

- On June 3,1998, the Deputy Secretary sent a letter to the Board forwarding a report that outlined the Department's program for assessing work performance and tracking related to corrective actions in response to the Board's March 20, 1998, letter.

- On June 4, 1998, the Acting Assistant Secretary for Environmental Management sent a letter to the Board forwarding a revised Integrated Program Plan for Recommendation 94-3.

- On June 5, 1998, the Acting Assistant Secretary of Environmental Management sent a letter to the Board which forwarded the system requirements document for Uranium-233 as a deliverable under the 97-1 Implementation Plan.

- On June 8, 1998, the Deputy Assistant Secretary for Military Application and Stockpile Management sent a letter to the Board forwarding the 94-4 Quarterly Report covering activities occurring between January 1 and March 31, 1998.

- On June 11, 1998, the Secretary sent a letter to the Board asking the Board to submit a declaration to the Department of Justice concerning the safe startup and operation of the Waste Isolation Pilot Plant.

- On June 16,1998, the Departmental Representative to the Defense Nuclear Facilities Safety Board sent the Board copies of five 94-1 Implementation Plan changes that were previously approved by the Secretary and submitted to the Board.

- On June 17, 1998, the Acting Assistant Secretary for Environmental Management sent a letter to the Board forwarding the Department's quarterly progress report on implementation of Recommendation 94-3.

- June 18, 1998, Department letter to the Board forwarding updated information on the status of ISM.

- On June 23, 1998, the Department sent a letter to the Board that forwarded a Quarterly Report on the status of Recommendation 94-1. 
- On June 29, 1998, the Department sent a letter to the Board proposing closure of Commitment 5.2.1.1 of the Implementation Plan for Recommendation 93-3.

- On July 6, 1998, the Department sent a letter to the Board providing a July 31,1998 , completion date for a response to the Board's March 18, 1998, letter concerning the Spent Nuclear Fuel Project at Hanford.

- On July 7, 1998, the Under Secretary sent a letter to the Board in response to the Board's letter of March 11, 1998, relating to readiness and current status of the of H-Canyon Phase II Restart.

- On July 9,1998 , the Department sent a letter to the Board forwarding a report that describes the Department's activities related to the management of low-level waste during the first quarter of commitments in the 94-2 Implementation Plan.

- On July 10, 1998, the Department sent a letter to the Board to advise the Board of the completion of radiological assessment for low-level waste disposal facilities in accordance with Recommendation 94-2 Implementation Plan.

- On July 10,1998 , the Department sent a letter to the Board transmitting information concerning the feedback and improvement processes under integrated safety management, a summary of safeguards and security issues at each site, and site corrective action status.

- July 10,1998 , Department letter to the Board concerning reservoir storage in highly invulnerable encased safes (HIVES). July 22, 1998, Department letter forwarding milestone 5.6.3.1.h per the 93-5 implementation plan.

- On July 17, 1998, the Acting Assistant Manager for High Level Waste sent a letter to the Board forwarding Recommendation 96-1 deliverables.

- On July 21, 1998, the Under Secretary of Energy sent a letter to the Board forwarding corrective actions to the Board's onsite review of the Hanford Spent Nuclear Fuel Project.

- On July 21, 1998, the Manager of the Savannah River Operations Office sent a letter to the Board describing safety margins for new Savanna River facility designs; forwarding a plan demonstrating the Actinide Packaging and Storage Facility safety margins; and providing an up-date on the current status and issue resolutions concerning the development of the Savannah River ground motion detector. 
- On July 24, 1998, the Acting Assistant Secretary for Environmental Management sent a letter to the Board forwarding the uranium-233 waste threshold criteria document prepared as a deliverable under the 97-1 Implementation Plan.

- On July 27, 1998, the Deputy Assistant Secretary for Military Application and Stockpile Management for Defense Programs sent a letter to the Board forwarding a semi-annual line management update regarding access to nuclear weapons data and expertise.

- July 27,1998 , Department letter to the Board forwarding the quarterly progress report for the period from April 1, 1998, to June 30, 1998, per the 94-2 implementation plan.

- On July 28, 1998, the Manager of Richland Operations Office sent a letter to the Board transmitting a quarterly report for Recommendation 93-5.

- On July 30, 1998, the Manager of Richard Operations Office sent a letter to the Board forwarding a quarterly report for Recommendation 92-4.

- On August 4, 1998, the Deputy Assistant Secretary for Research and Development in Defense Programs sent a letter to the Board forwarding the 97-2 quarterly status report.

- On August 11, 1998, the Defense Program's Deputy Assistant Secretary for Military Application and Stockpile Management sent a response to the Board's June 1, 1998, letter that requested additional information on the process by which the Department performs change control for its nuclear explosive operations at the Pantex Plant.

- On August 14, 1998, the Acting Secretary sent a letter to the Board responding to a May 14, 1998, letter to former Secretary Peña requesting information on evaluations and assessments of proposals to externally regulate the Department's defense nuclear facilities, for assistance in preparation of a formal report to Congress.

- On August 18, 1998, the Assistant Secretary for Defense Programs sent a letter to the Board agreeing with the Board's assessment of fundamental problems with control of the maintenance activities at the Y-12 Plant and forwarding a corrective action plan in response to the Board's letter of June 12, 1998.

- On August 20, 1998, the Deputy Assistant Secretary for Military Application and Stockpile Management for Defense Programs sent a letter to the Board forwarding a quarterly progress report and the July deliverables for the recommendation 94-4 Implementation Plan. 
- On August 24, 1998, the Acting Assistant Secretary for Environmental Management sent a letter to the Board responding to the Board's letter of July 10, 1998, with concerns about the americium-curium stabilization program at the Savannah River Site.

- On August 31, 1998, the Under Secretary sent a letter to the Board responding to the April 15, 1998, letter from the Board requesting a status report on the readiness review process at Hanford.

- On August 31, 1998, the Under Secretary of Energy sent a letter to the Board forwarding the Department's responses to issues raised in the Board's letter of March 18, 1998, concerning the spent nuclear fuel project at Hanford.

- On September 2, 1998, the Secretary sent a letter to the Board forwarding the technical update to the Recommendation 94-1 Implementation Plan.

- September 2, 1998, Department letter to the Board forwarding the quarterly progress report per the 94-3 implementation plan.

- On September 9, 1998, the Under Secretary of Energy sent a letter to the Board forwarding the status of recommendation 94-1 milestones at the Plutonium Finishing Plant.

- On September 11, 1998, the Acting Assistant Secretary for Environmental Management sent a letter to the Board forwarding a response that addressed the five issues detailed in the Board's July 13, 1998, letter concerning the Plutonium Finishing Plant at Hanford.

- On September 17, 1998, the Acting Assistant Secretary for Environmental Management sent a letter to the Board that forwarded the "Low-Level Waste Disposal Facility Federal Review Group Manual" as a deliverable under the 94-2 Implementation Plan.

- On September 17, 1998, the Acting Assistant Secretary for Environmental Management sent a letter to the Board forwarding a revision to "The Current and Planned Low-level Waste Disposal Capacity Report" as a deliverable under the 94-2 Implementation Plan.

- On September 18, 1998, the Deputy Assistant Secretary for Military Application and Stockpile Management for Defense Programs sent a letter to the Board that provided clarification on the Board's staff report titled "Surveillance of Nuclear Weapon HighExplosive Operations at Pantex which had been provided in a letter from the board on March 4, 1998. 
- On September 24, 1998, the Acting Assistant Secretary for Environment, Safety and Health sent a letter to the Board responding to a September 10, 1998, letter from the Board requesting a status report on response from the Department Field Elements concerning fire safety programs.

- On September 29, 1998, the Acting Assistant Secretary for Environmental Management sent a letter to the Board forwarding a list of schedule milestones for the Hanford Spent Nuclear Fuel Project.

- On October 1, 1998, the Acting Assistant Secretary for Environmental Management sent a letter to the Board forwarding a deliverable under the Implementation Plan for Recommendation 94-2, entitled Complex-wide Strategy for Maintenance of Department of Energy Low-level Waste Disposal Facility Performance Assessments and Composite Analyses.

- On October 1, 1998, the Acting Deputy Assistant Secretary for Nuclear Material and Facility Stabilization for Environmental Management sent a letter to the Board forwarding the Uranium-233 Storage Alternative Trade Study Final Report as a deliverable under the Implementation Plan for Recommendation 97-1.

- On October 2, 1998, the Acting Assistant Secretary for Environmental Management sent a letter to the Board forwarding a compliance evaluation and a disposal authorization for the Los Alamos National Laboratory Low-Level Waste Disposal Area G, as a deliverable under the Implementation Plan for Recommendation 94-2.

- On October 2, 1998, the Acting Deputy Assistant Secretary for Nuclear Material and Facility Stabilization for Environmental Management sent a letter to the Board forwarding the final uranium-233 technical standard as a deliverable under the Implementation Plan for Recommendation 97-1.

- On October 14, 1998, the Deputy Assistant Secretary for Military Application and Stockpile Management sent a letter to the Board responding to their letter of August 26,1998 , and committing to provide a copy of the Integrated Pit Storage Program Plan by the end of October.

- October 19, 1998, Department letter to the Board forwarding comments on the Board's draft report on external regulation.

- On October 20, 1998, the Acting Assistant Secretary for Environmental Management sent a letter to the Board forwarding deliverables under the 94-3 Implementation Plan. 
- On October 20, 1998, the Acting Assistant Secretary for Environmental Management sent a letter to the Board notifying them of a missed milestone under the Implementation Plan for Recommendation 94-1 to complete the removal of liquids in Building 771.

- On October 22, 1998, the Under Secretary sent a letter to the Board proposing a change to the Implementation Plan for Recommendation 97-1 to include the system description in the program execution plan deliverable vice a separate deliverable.

- On October 23, 1998, the Acting Assistant Secretary for Environmental Management sent a letter to the Board forwarding the quarterly report under the Implementation Plan for Recommendation 94-2.

- On October 28, 1998, the Savannah River Operations Office Manager sent a letter to the Board providing the status of progress made relative to stabilization of americium/curium solutions at the site.

- On October 29, 1998, the Executive Secretary to the Federal Technical Capability Panel sent a letter to the Board announcing the completion of the Phase 1 technical qualification program assessments at all sites.

- On October 29, 1998, the Manager of the Richland Operations Office sent the Board a letter forwarding quarterly status report concerning Hanford waste tank characterization studies as a deliverable under the 93-5 Implementation Plan.

- On October 30, 1998, the Deputy Assistant Secretary for Research and Development for Defense Programs forwarded a quarterly status report concerning criticality safety as a deliverable under the 97-2 Implementation Plan.

- On November 6,1998, the Deputy Assistant Secretary for Military Application and Stockpile Management for Defense Programs sent a letter to the Board providing Revision 1 of the Integrated Pit Storage Program Plan.

- On November 20,1998, the Secretary sent a letter to the Board accepting the Board's recommendation 98-1, resolution of internal safety oversight findings, and identifying the foundation and focus of the Implementation Plan.

- On November 20,1998, the Secretary sent a letter to the Board accepting the Board's recommendation $98-2$, safety management at Pantex, and identifying the approach for the Implementation Plan. 
- On November 20,1998, the Secretary sent a letter to the Board forwarding the results of the Department's review of the Board's draft report to Congress on external regulation.

- November 25, 1998, Department letter to the Board forwarding the completion of milestone 5.4.3.6.c per the 93-5 implementation plan.

- On November 25, 1998, the Acting Assistant Secretary for Environment, Safety and Health sent a letter to the Board concerning the importance of the joint U.S./Russia radiation health effects studies conducted under the auspices of the U.S./Russian Joint Coordinating Committee for Radiation Effects Research.

- November 30, 1998, Department letter to the Board forwarding a description of how the model policies and procedures to preserve Facility Representative capabilities and positions have been implemented per the 93-3 implementation plan.

- December 7, 1998, Department letter to the Board forwarding the quarterly progress report per the 94-3 implementation plan.

- December 10,1998, Department letter to the Board forwarding comments regarding the U.S./Russian Joint Coordinating Committee for Radiation Effects Research (JCCRER).

- On December 15, 1998, the Department sent a letter to the Board responding to an October 8,1998, letter concerning addresses to actions taken to correct the Holden Gas Furnace noncompliance and additional concerns of the Board's staff.

- On December 16,1998, the Secretary sent a letter to the Board proposing closure of the Board's recommendation 92-4.

- On December 17, 1998, the Assistant Secretary for Defense Programs responded to a Board letter dated November 17, 1998, that requested plans and a resource loaded schedule for Department review and approval activities related to the performance of certain classified Los Alamos National Laboratory projects as well as qualification, and affiliations of those individuals assigned to the activities.

- On December 22, 1998, the Manager of the Idaho Operations Office sent a letter to the Board forwarding the final site assessment report on the storage of Uranium-233, a Recommendation 97-1 Implementation Plan deliverable. 
- On December 28, 1998, the Secretary sent a letter to the Board with the approved revision to the Implementation Plan for the Board's Recommendation 94-1, entitled Remediation of Nuclear Materials in the Defense Nuclear Facilities Complex.

- On December 28, 1998, the Executive Secretary to the Federal Technical Capability Panel sent a letter to the Board forwarding the revised Administrative flexibility Manger's Guide as a deliverable under the Implementation Plan for the Recommendation 93-3.

- $\quad$ On December 28, 1998, the Executive Secretary to the Federal Technical Capability Panel sent a letter to the Board forwarding the approved Federal Technical Capability Policy as a deliverable under the Implementation Plan for the Board's Recommendation 93-3.

- On December 28, 1998, the Manager of Richland Operations Office sent a letter to the Board with a report summarizing the review of the Hanford Defined Waste, Revision IV, Model Limitations as a deliverable under the Implementation Plan for the Recommendation 93-5. 